STATE OF FLORIDA

DEPARTMENT OF ENVIRONMENTAL PROTECTION

Virginia B. Wetherell, Secretary

DIVISION OF ADMINISTRATIVE AND TECHNICAL SERVICES

Nevin Smith, Director

FLORIDA GEOLOGICAL SURVEY

Walter Schmidt, State Geologist and Chief

INFORMATION CIRCULAR NO. 111

1994 AND 1995 FLORIDA PETROLEUM

PRODUCTION AND EXPLORATION

By

Jacqueline M. Lloyd
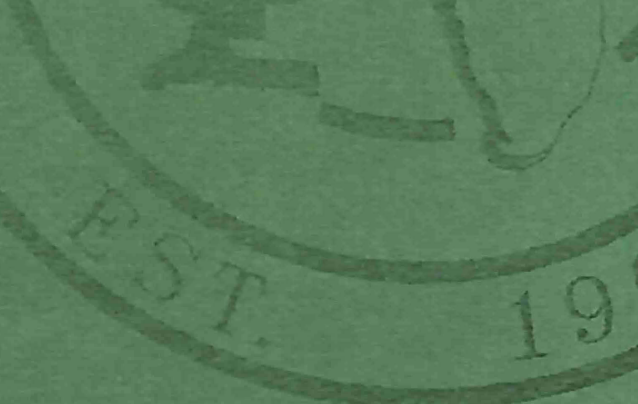

Published for the

FLORIDA GEOLOGICAL SURVEY

Tallahassee

1997 


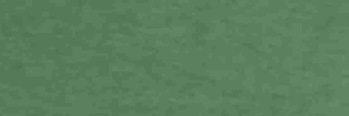

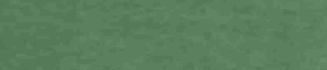

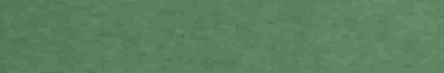

(15)

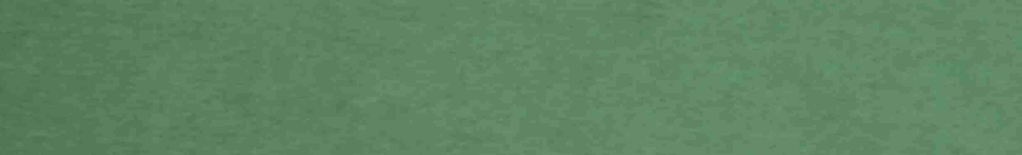

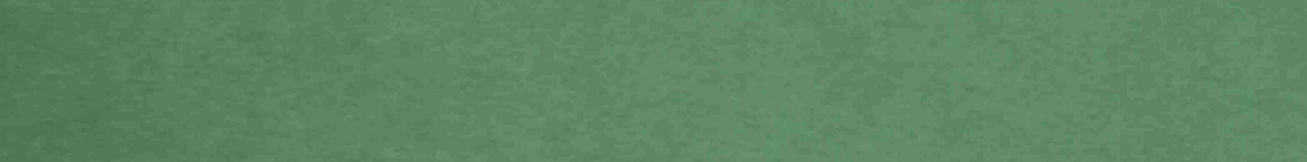

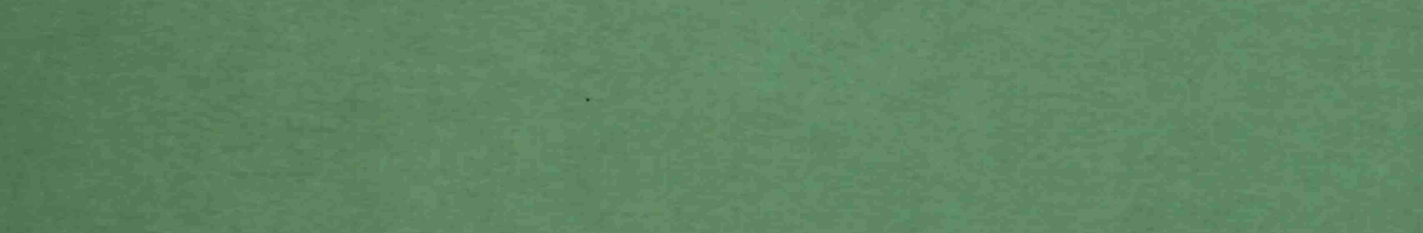

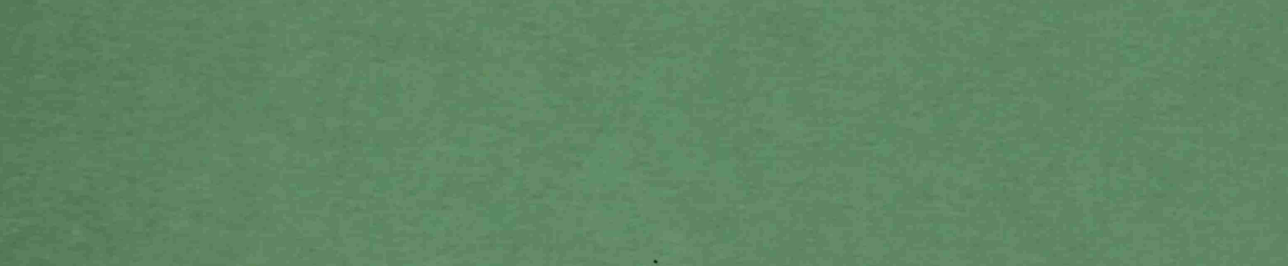
$\frac{1}{2} x^{2}-2 x$
$2 \ln ^{2}$

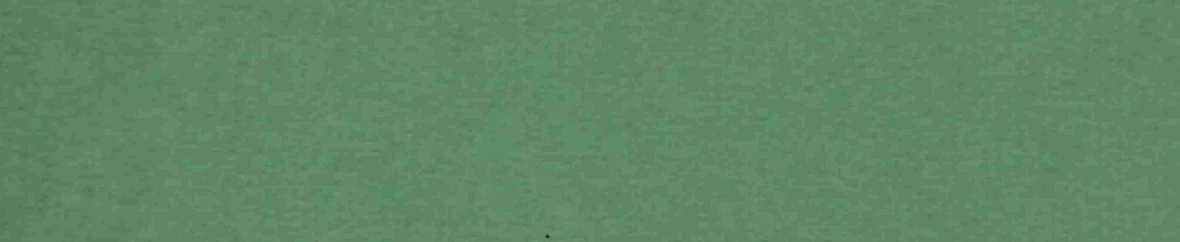

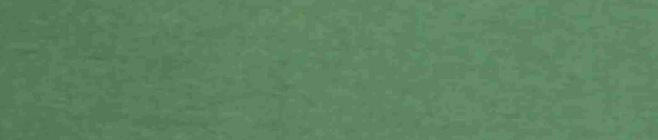

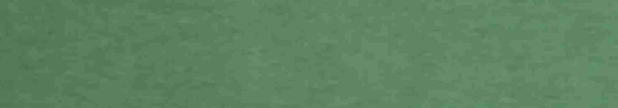

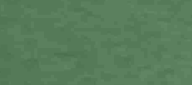

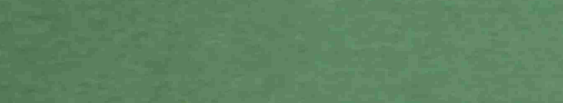

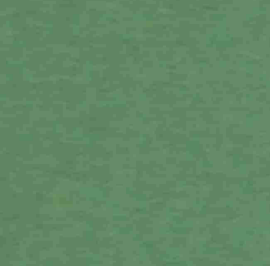

$1+\frac{16}{2}$

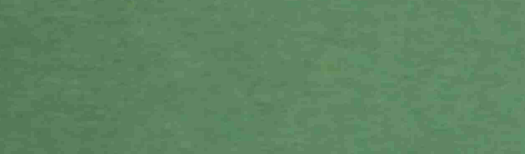

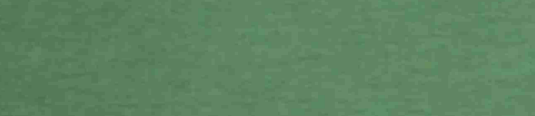

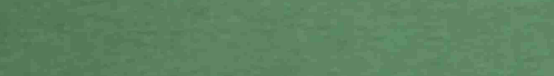

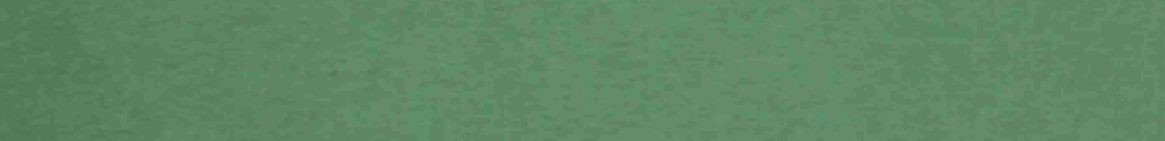

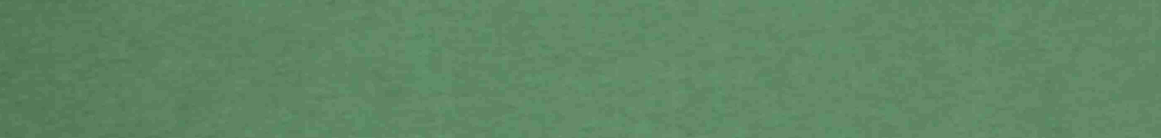

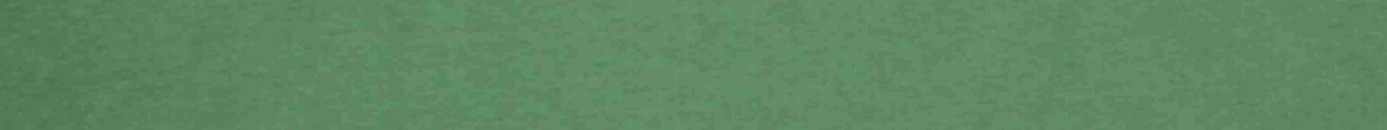

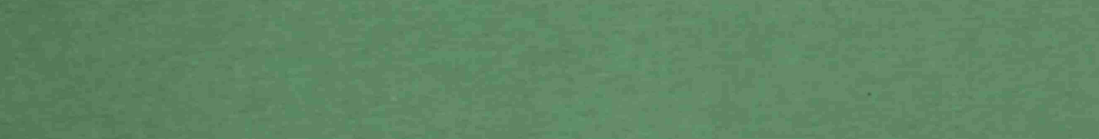

H.

125 


\section{STATE OF FLORIDA \\ DEPARTMENT OF ENVIRONMENTAL PROTECTION \\ Virginia B. Wetherell, Secretary}

DIVISION OF ADMINISTRATIVE AND TECHNICAL SERVICES

Nevin Smith, Director

FLORIDA GEOLOGICAL SURVEY

Walter Schmidt, State Geologist and Chief

INFORMATION CIRCULAR NO. 111

1994 AND 1995 FLORIDA PETROLEUM

PRODUCTION AND EXPLORATION

By

Jacqueline M. Lloyd

Published for the

FLORIDA GEOLOGICAL SURVEY

Tallahassee

1997 


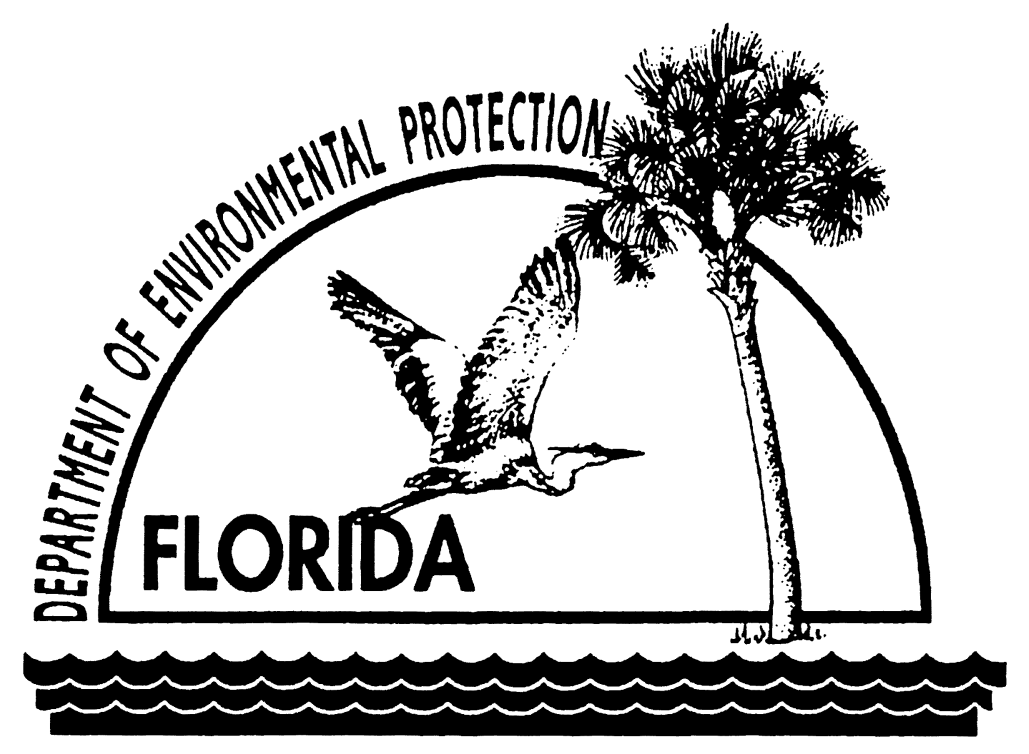

Printed for the

Florida Geological Survey

Tallahassee

1997

ISSN 0085-0616 


\section{LETTER OF TRANSMITTAL}

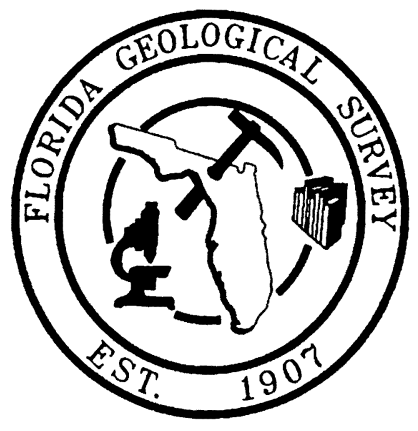

Florida Geological Survey

Tallahassee

Governor Lawton Chiles

Florida Department of Environmental Protection

Tallahassee, Florida 32301

Dear Governor Chiles:

The Florida Geological Survey, Division of Administrative and Technical Services, Department of Environmental Protection, is publishing "1994 and 1995 Florida Petroleum Production and Exploration" as its Information Circular 111. This information is useful to the state and to the oil and gas industry in planning wise development and conservation of Florida's oil and gas resources.

Respectfully yours,

Walter Schmidt, Ph.D., P.G.

State Geologist and Chief

Florida Geological Survey 


\section{TABLE OF CONTENTS}

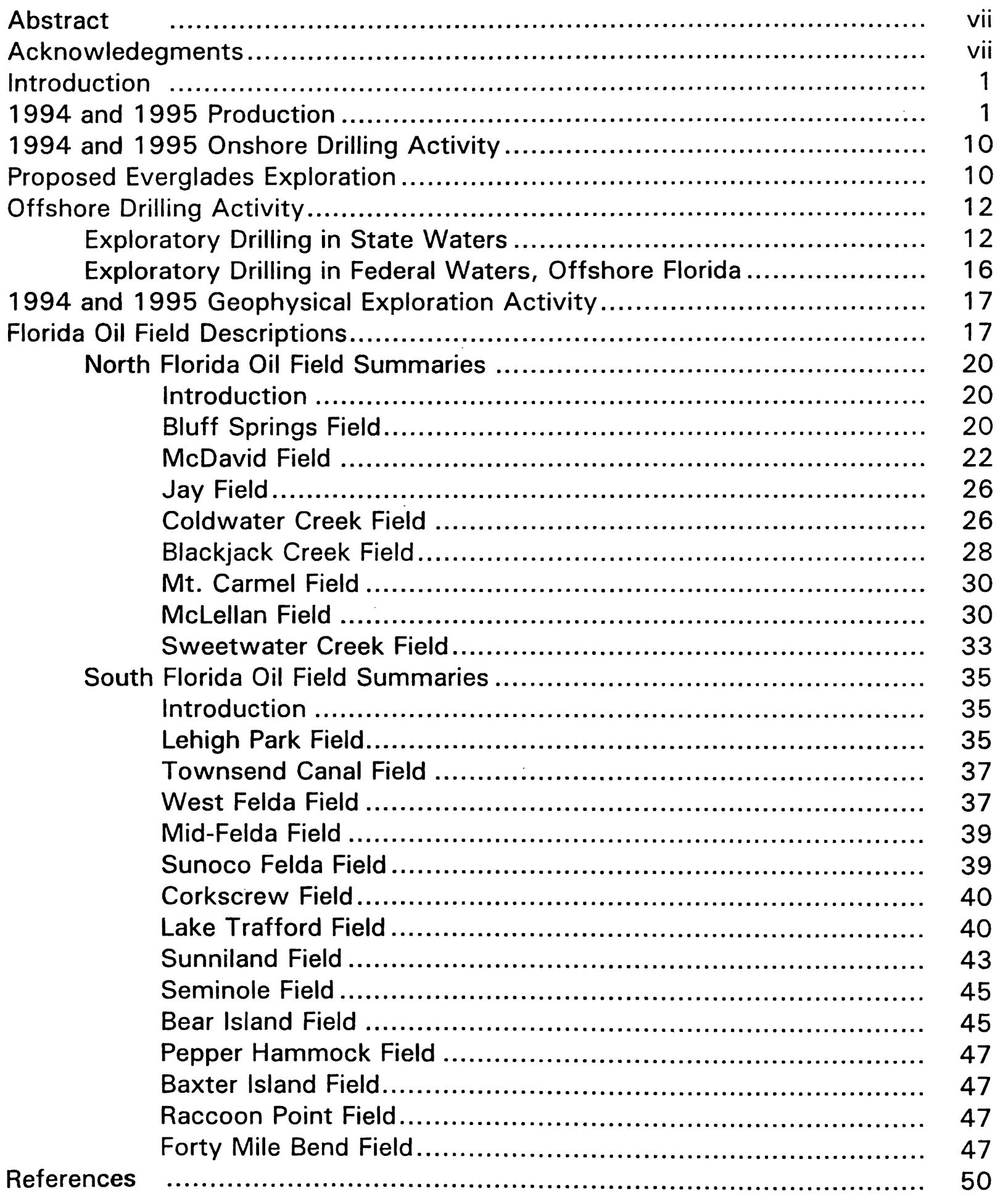




\section{ILLUSTRATIONS}

1. South Florida oil field location map....................................... 2

2. Stratigraphic nomenclature, Upper Jurassic to Lower Cretaceous, south Florida (1)

3. Northwest Florida oil field location map .................................. 4

4. Stratigraphic nomenclature, Middle Jurassic to Lower Cretaceous, northwest Florida.

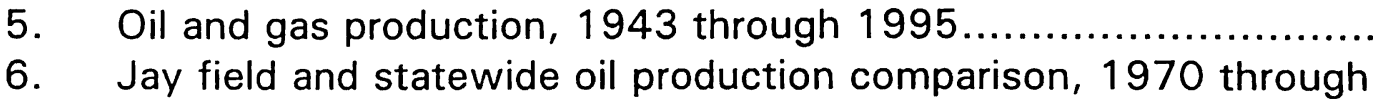
1995

7. 1993,1994 , and 1995 oil production comparison for active Florida oil fields, excluding Jay field ................................................ 9

8. Updated map of 1992 and 1993 exploration wells...................... 11

9. Exploration wells, Florida state waters, including Coastal Petroleum's proposed exploratory well locations.................................... 13

10. 1994 and 1995 geophysical exploration activity ........................ 14

11. Mesozoic structural features in Florida and offshore .................... 15

12. Exploration wells and historic leases, federal waters, offshore Florida... 18

13. Bluff Springs and McDavid fields structure map, top of Smackover

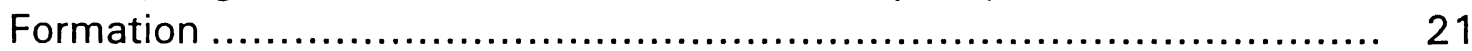

14. Geophysical log correlation, Bluff Springs and McDavid fields........... 23

15. McDavid field production curve........................................ 25

16. Jay field structure map, top of Smackover Formation .................... 27

17. Blackjack Creek field structure map, top of Smackover Formation....... 29

18. Mt. Carmel field structure map, top of Norphlet Sandstone .............. 31

19. McLellan and Sweetwater Creek fields well location map................ 32

20. Geophysical log correlation, McLellan field .............................. 34

21. Lehigh Park field structure map, top of Sunniland Formation............. 36

22. Sunoco Felda, West Felda, and Mid-Felda fields structure map, top of

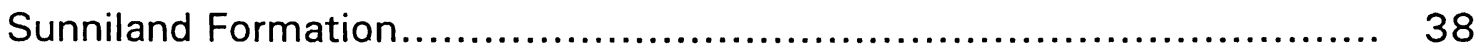

23. Corkscrew field structure map, top of Sunniland Formation.............. 41

24. Lake Trafford field structure map, top of rubble zone, Sunniland

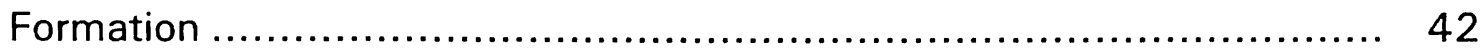

25. Sunniland field structure map, top of Sunniland Formation ............... 44

26. Bear Island field structure map, base of anhydrite in Upper Sunniland Formation ............................................................... 46

27. Raccoon Point field structure map, top of Sunniland porosity ........... 48 


\section{APPENDICES}

1. Florida oil field discovery well data ...................................... 55

2. 1994,1995 and cumulative production data............................ 56

3. 1994 and 1995 field well statistics..................................... 57

4. $\quad 1994$ and 1995 field wells drilled ...................................... 58

5. Exploratory well drilled in 1993; completion report received in $1994 \ldots . .58$

6. Oil exploration wells drilled in Florida state waters ....................... 59

7. 1994 and 1995 geophysical exploration activity ....................... 61

8. Florida oil and gas reserve estimates .................................. 62 


\section{ABSTRACT}

Florida oil production began to decline in 1979 and generally has continued to do so; however, production increased by eight percent from 1993 to 1994. Production then declined by six percent during 1995. Two of the south Florida oil fields (Sunoco Felda and Sunniland) are nearing the end of their production history. The last reported production from Sunniland field was in 1991 and the last reported production from Sunoco Felda field was in 1992.

Exploration activity during 1994 and 1995 was very limited. There were no exploratory wells drilled, however, one well which was completed in 1993 is included in this report because the completion report was received in 1994. This Santa Rosa County well was plugged and abandoned as a dry hole.

Geophysical exploration during 1994 and 1995 covered only 22.5 miles of seismic lines in the Florida panhandle, 20.3 miles of seismic lines in south Florida, and 102 miles of gravity survey in south Florida. In addition to this completed geophysical exploration, a permit application was pending for an extensive offshore seismic, gravity, and magnetic survey. A similar area was covered by an approved permit during 1992/93 but the permit expired with only minimal magnetic exploration having been conducted. This exploration would potentially explore a dense grid off Florida's Gulf coast extending from offshore of Apalachicola, Franklin County to offshore of Naples, Collier County.

One exploratory well was being drilled in federal waters off Florida at the close of 1995. This well will be the fourth drilled in the Destin Dome area by Chevron. Two of the previously drilled wells were classified by the federal government as producible Norphlet gas discoveries.

A summary of offshore exploratory drilling is included in this report, as well as descriptions of each of Florida's 22 oil fields. The descriptions include discovery data, geologic information, and production totals.

\section{ACKNOWLEDGEMENTS}

Several Florida Geological Survey staff members contributed to this report. Special recognition goes to Jim LeBar, Petroleum Engineer with the FGS Oil and Gas Section, for his significant contributions. Jim updated several field structure maps, compiled production statistics, and provided historical and current information on field development, production and exploration. Don Hargrove and Ed Garrett assisted in using and interpreting well and geophysical permit files. Ed Garrett, Jim LeBar, Tom Scott, Walt Schmidt, Deborah Mekeel and Ed Lane reviewed the manuscript and suggested improvements. Jim Jones and Ted Kiper provided base maps, reviewed and suggested improvements to the graphics, and drafted some of the original figures which were updated from earlier petroleum reports. Kim Staubinger (Accounting Systems Analyst, Florida Department of Revenue) provided oil and gas severance tax data. 
Information Circular 111

\title{
1994 AND 1995 FLORIDA PETROLEUM PRODUCTION AND EXPLORATION
}

By

\author{
Jacqueline M. Lloyd, P.G. \#74
}

\section{INTRODUCTION}

There are two major oil producing areas in Florida. One is the Sunniland trend in south Florida and the other is the Jay trend in the western panhandle area. The Sunniland trend includes 14 oil fields; the western panhandle includes eight. Appendix 1 lists the discovery well data for these fields.

South Florida production began with Florida's first oil discovery at Sunniland field in September, 1943. Of the 14 south Florida oil fields, seven are active, three are temporarily shutin, and four are plugged and abandoned. These fields are oriented along a northwest-southeast trend through Lee, Hendry, Collier, and Dade Counties (Figure 1). This trend has become known as the Sunniland trend. Production is principally from rudistid reefs found in the upper one hundred feet of the Lower Cretaceous Sunniland Formation (Figure 2). Depth to Sunniland production averages about 11,500 feet.

Production in the western panhandle began with the discovery of Jay field in June, 1970. The eight panhandle oil fields are located in Escambia and Santa Rosa Counties, Florida (Figure 3). Five fields are active and three are plugged and abandoned. Production is from Upper Jurassic
Smackover Formation carbonates and Norphlet Sandstone sands (Figure 4). Depth to Jurassic production averages approximately 15,000 feet.

\section{AND 1995 PRODUCTION}

Appendix 2 lists 1994, 1995, and cumulative production statistics for each of Florida's oil fields including oil, gas, and water production data. Appendix 3 lists 1994 and 1995 field well statistics including the number of production, injection, shut-in, and temporarily abandoned wells for each field.

Florida oil production peaked at 47.5 million barrels in 1978 . Production began to decline in 1979 and generally has continued to do so since then (Figure 5). Total oil production for 1994, however, was $6,073,038$ barrels, up eight percent from 1993. Oil production then decreased by six percent during 1995 for a 1995 total of $5,681,618$ barrels. Total gas production increased five percent in 1994 and decreased 15 percent in 1995. Gas production totals were $8,446,904$ thousand cubic feet (MCF) in 1994 and $7,171,557 \mathrm{MCF}$ in 1995.

The short term increase in production in 1994 was due to an increase in production in both northwest Florida and south Florida. 
Florida Geological Survey

EXPLANATION

ACTIVE GIL FIELD
INACTIVE OIL FIELD

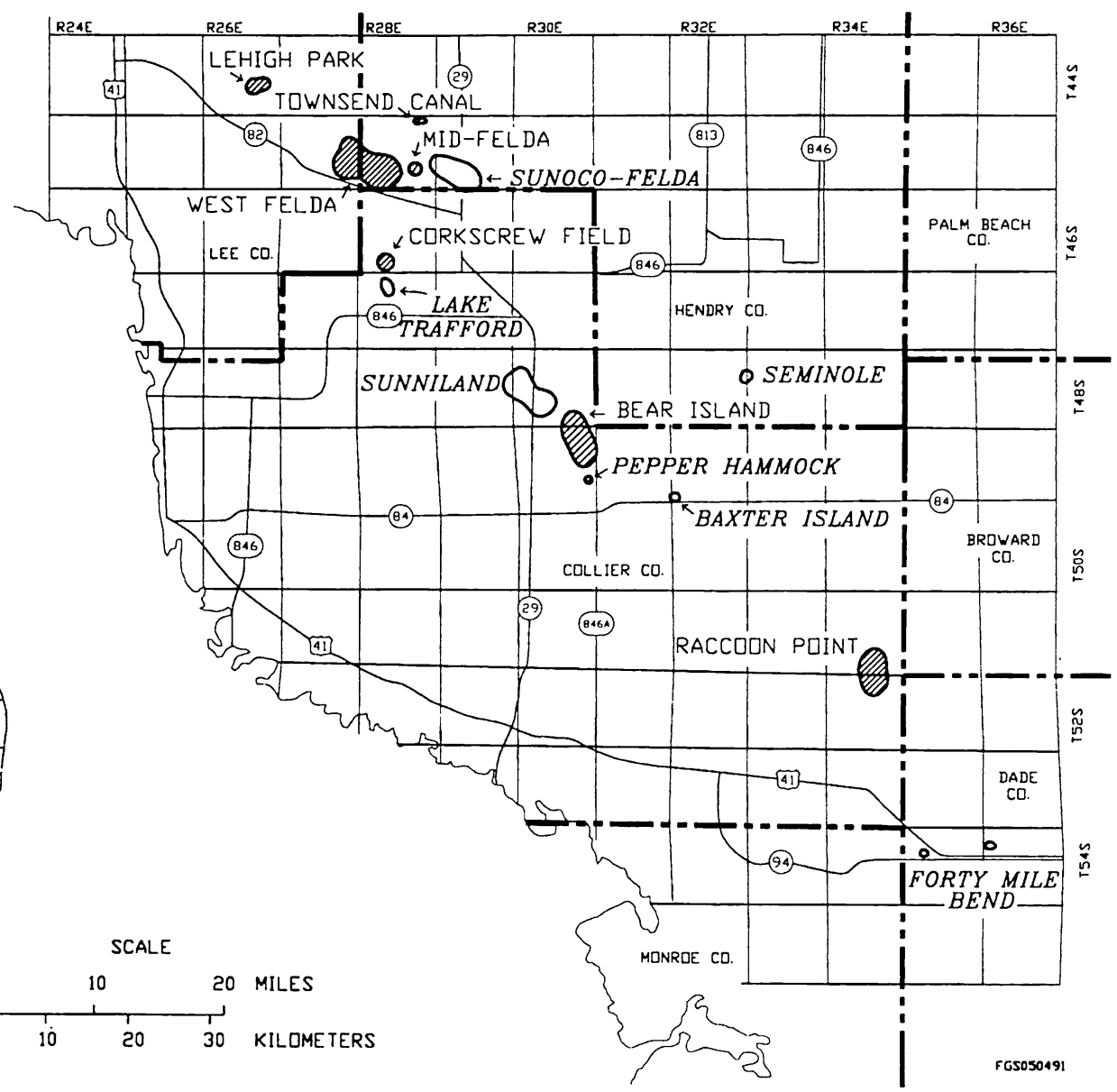

Figure 1. South Florida oil field location map 
Information Circular 111

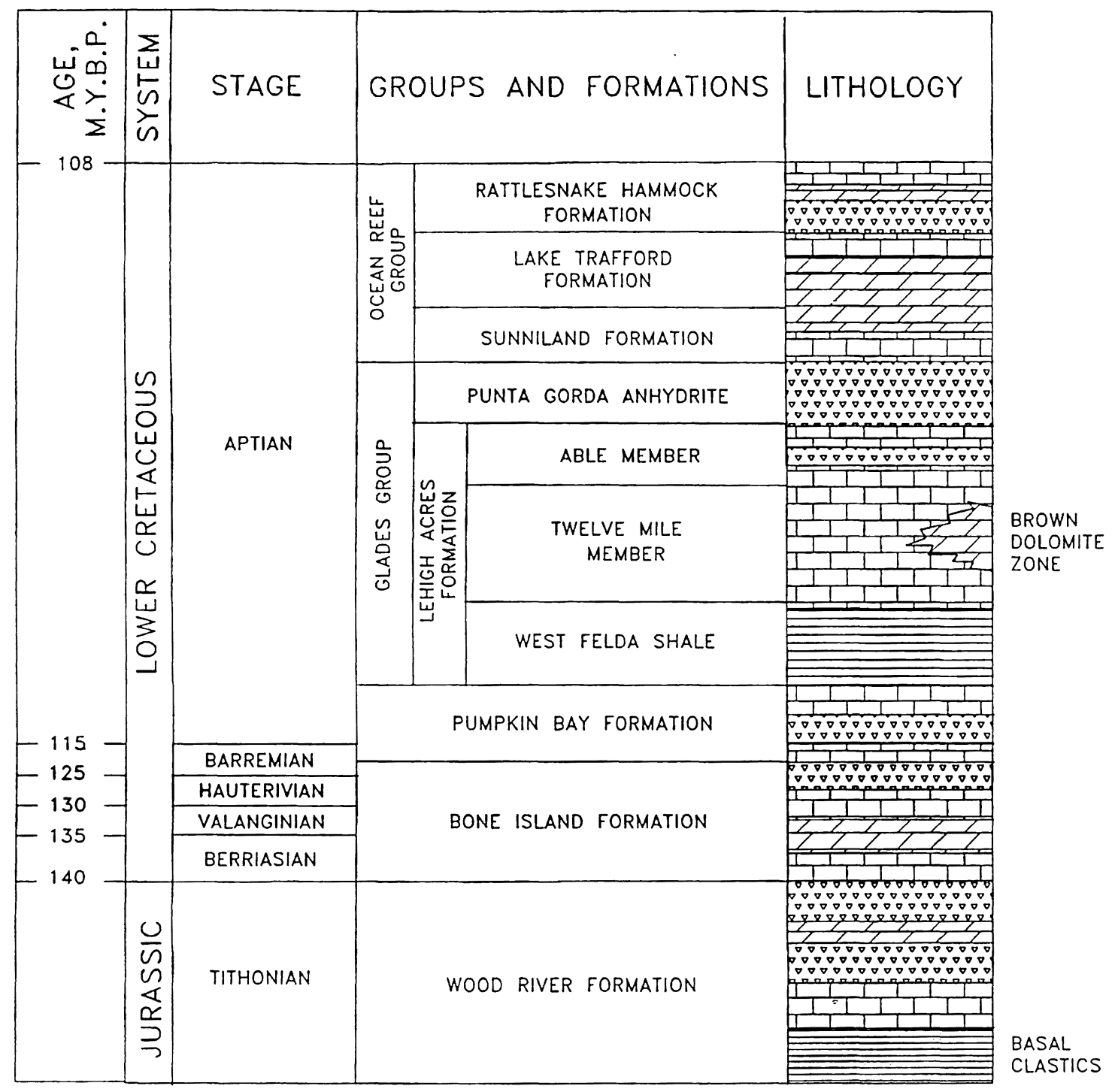

DOLOMITE

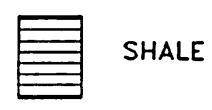

ANHYDRITE

FGS060491

Figure 2. Stratigraphic nomenclature, Upper Jurassic to Lower Cretaceous, south Florida. 
Florida Geological Survey

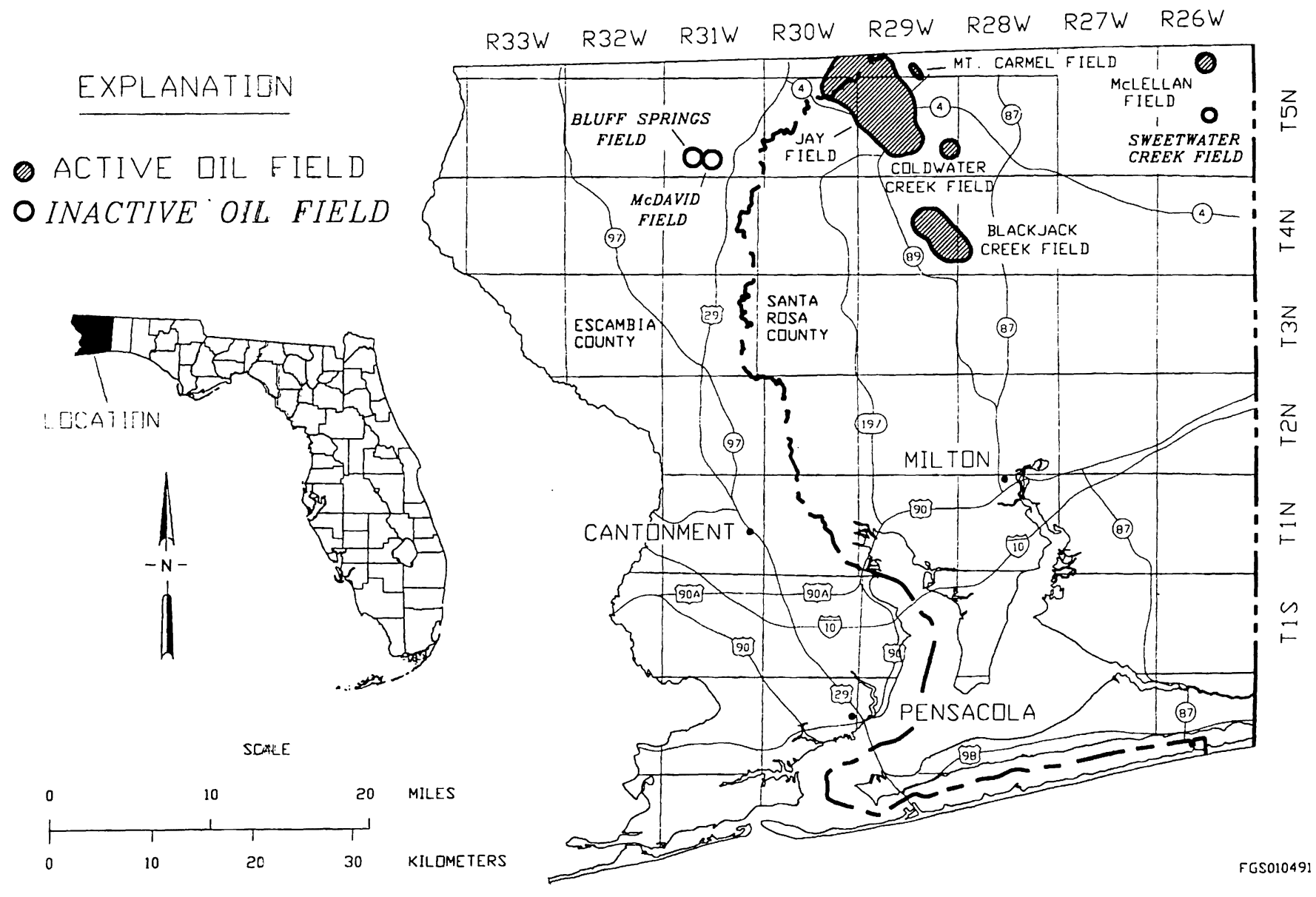

Figure 3. Northwest Florida oil field location map. 
Information Circular 111

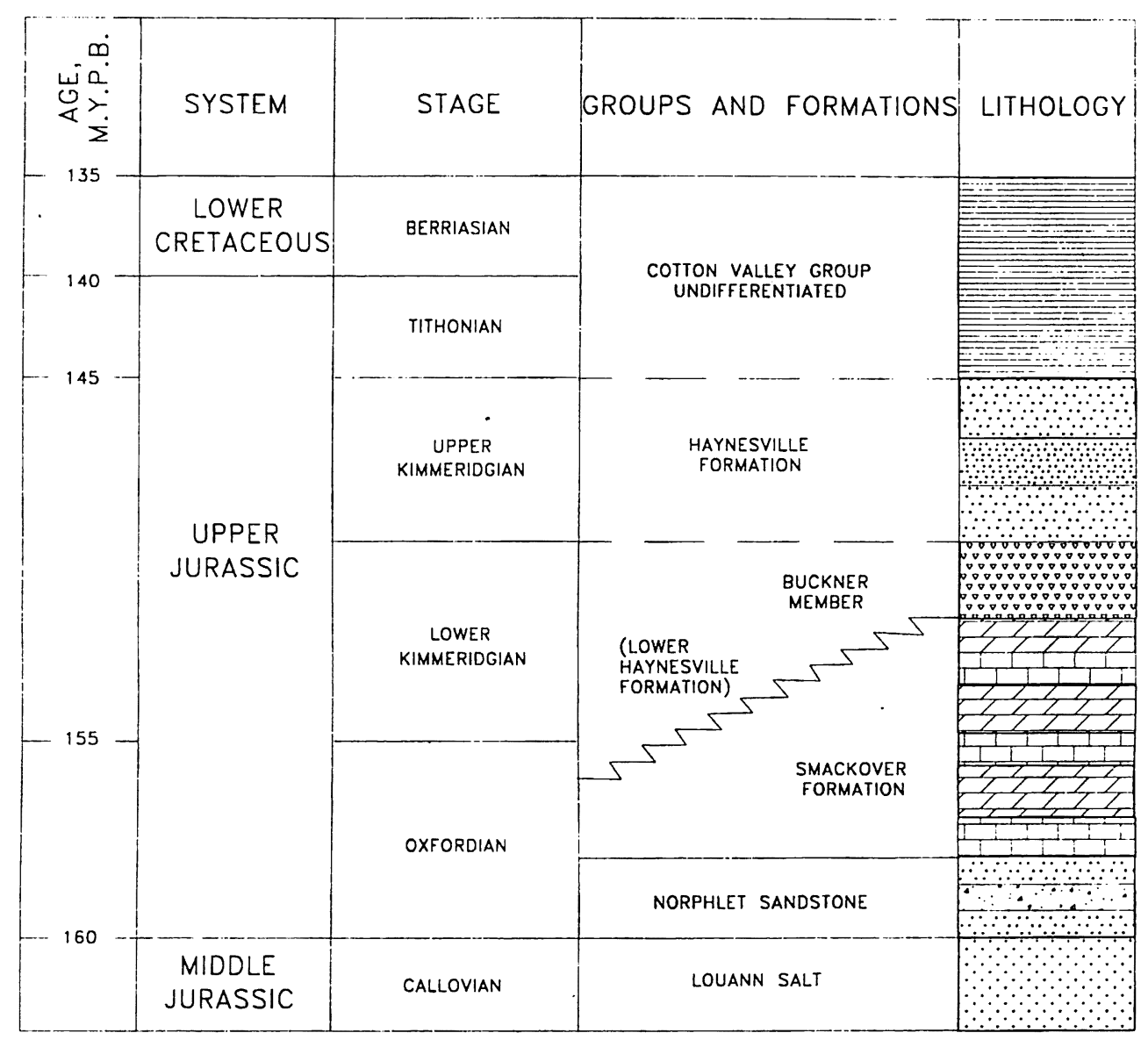

SANDSTONE

$\therefore$ CONGLOMERATE

LIMEstone DOLOMITE

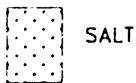

CLASTICS

FG5070491

Figure 4. Stratigraphic nomenclature, Middle Jurassic to Lower Cretaceous, northwest Florida. 
Florida Geological Survey
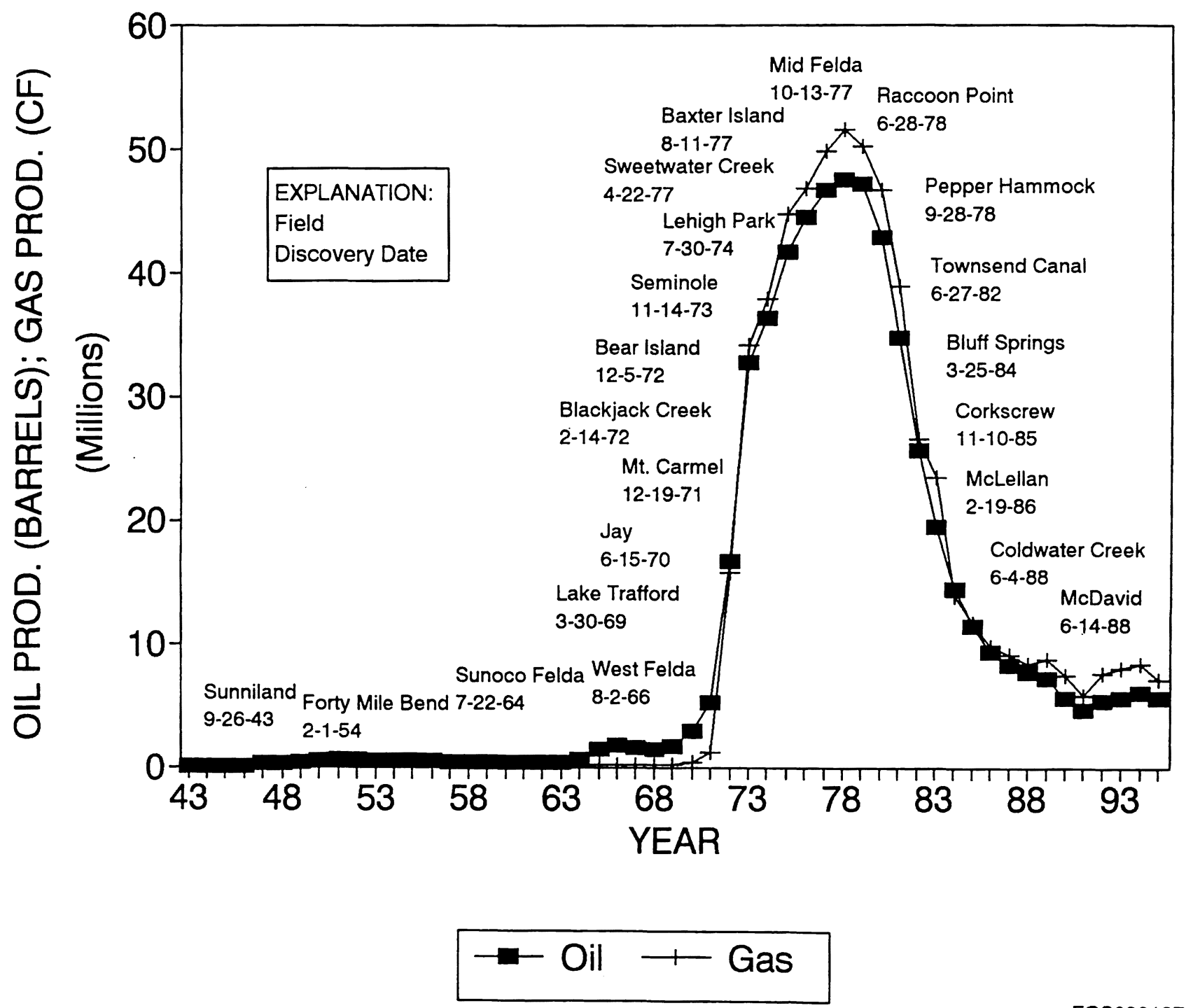

FGS020197

Figure 5. Oil and gas production, 1943 through 1995. 
The increase in south Florida oil production was most likely due to field or well-specific management (Ed Garrett, Professional Geologist, Florida Geological Survey, personal communication, 1996). The general trend, however, will probably continue to be a declining trend, with two of the south Florida oil fields recently at or near the end of their production history. The last reported production from Sunniland field was in 1991, while the last reported production from Sunoco Felda field was in 1992. All producing wells at Sunoco Felda have been plugged and abandoned. In addition, the single producing well at Lake Trafford field has been periodically shut-in due to mechanical problems and has been producing only sporadically since March 1988. Finally, the operator of Pepper Hammock field has proposed that the field's single well be plugged and abandoned because it is non-commercial (Jim LeBar, Petroleum Engineer, Florida Geological Survey, personal communication, 1996).

The Jay field was discovered in 1970 and reached peak production in 1978. It accounts for about 68 percent of the 1994 oil production total, about 67 percent of the 1995 total, and about 70 percent of the cumulative total. Figure 6 graphically compares statewide annual oil production with Jay field annual oil production for 1970 through 1995, clearly showing Jay field's dominance in Florida oil production trends. The Jay field production curve is typical of oil fields produced with tertiary recovery methods (David Curry, Oil and Gas Section Administrator, Florida Geological Survey, personal communication, 1992). Production has generally leveled off since 1987 (Figure $6)$. This agrees with the projections made by Christian et al. (1981) in their discussion of tertiary recovery estimates for Jay field. They estimated that tertiary recovery would be terminated in 1996, followed by rapid decline to depletion in about 2004. However, this type of level production is difficult to project because it depends, not only on enhanced recovery methods, but also on the price per barrel of oil. Current projections by Jim LeBar (Petroleum Engineer, Florida Geological Survey, personal communication, 1996) predict production through 2010.

Figure 7 is a histogram comparing 1993, 1994, and 1995 oil production for all Florida oil fields except the Jay field. Jay field data would obscure the information for all other fields since its production for 1993 was more than six times greater than that of Raccoon Point field, the next most productive field in Florida during 1993. Northwest Florida production increased by five percent from 1993 to 1994 and decreased by ten percent from 1994 to 1995 . South Florida production increased by 22 percent from 1993 to 1994 and by four percent from 1994 to 1995. Oil and gas severance taxes collected for 1994 and 1995 totaled 7.3 million dollars and 7.7 million dollars, 
Florida Geological Survey

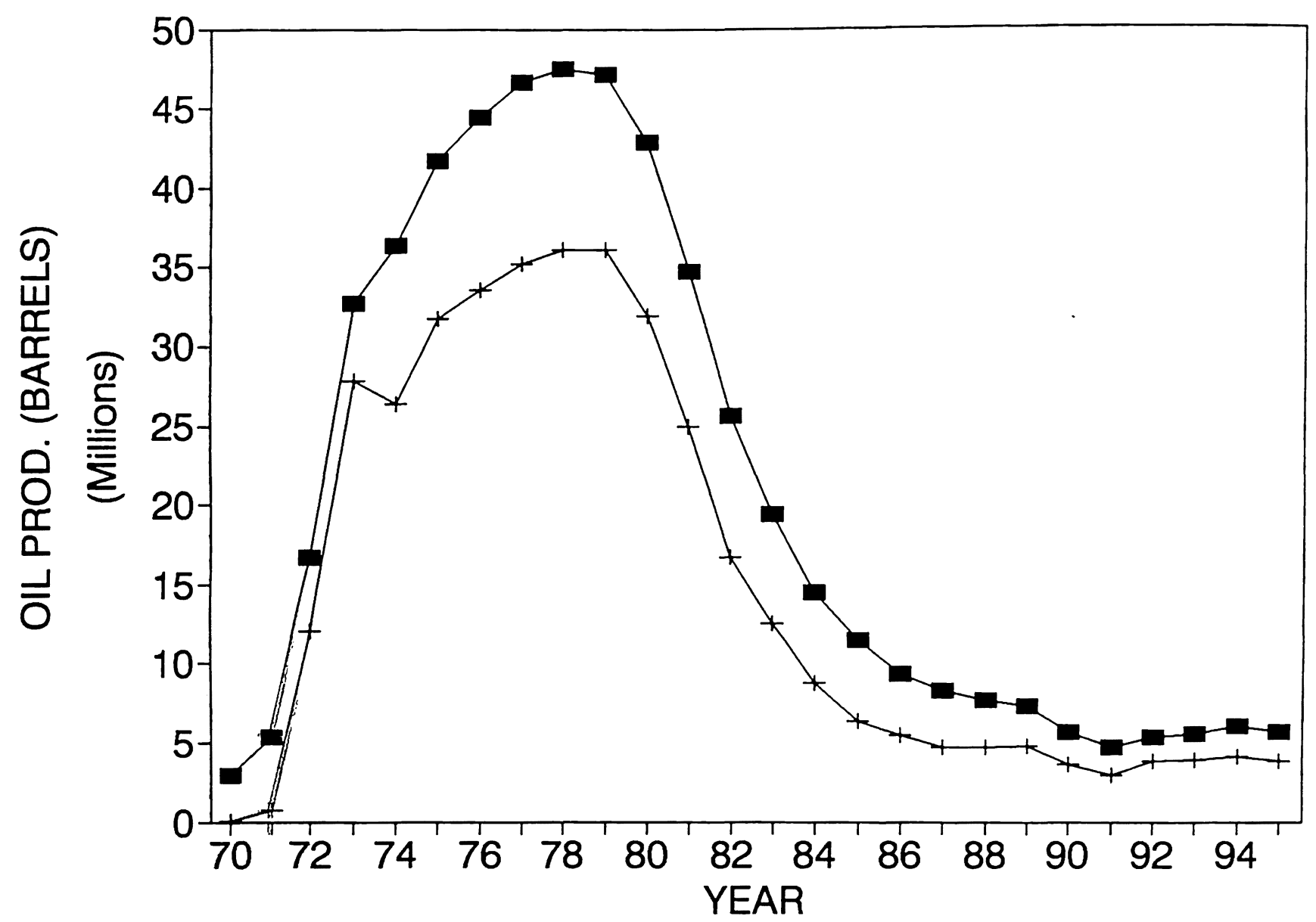

$\rightarrow$ Statewide + - Jay Field

FGS020297

Figure 6. Jay field and statewide oil production comparison, 1970 through 1995. 
Information Circular 111

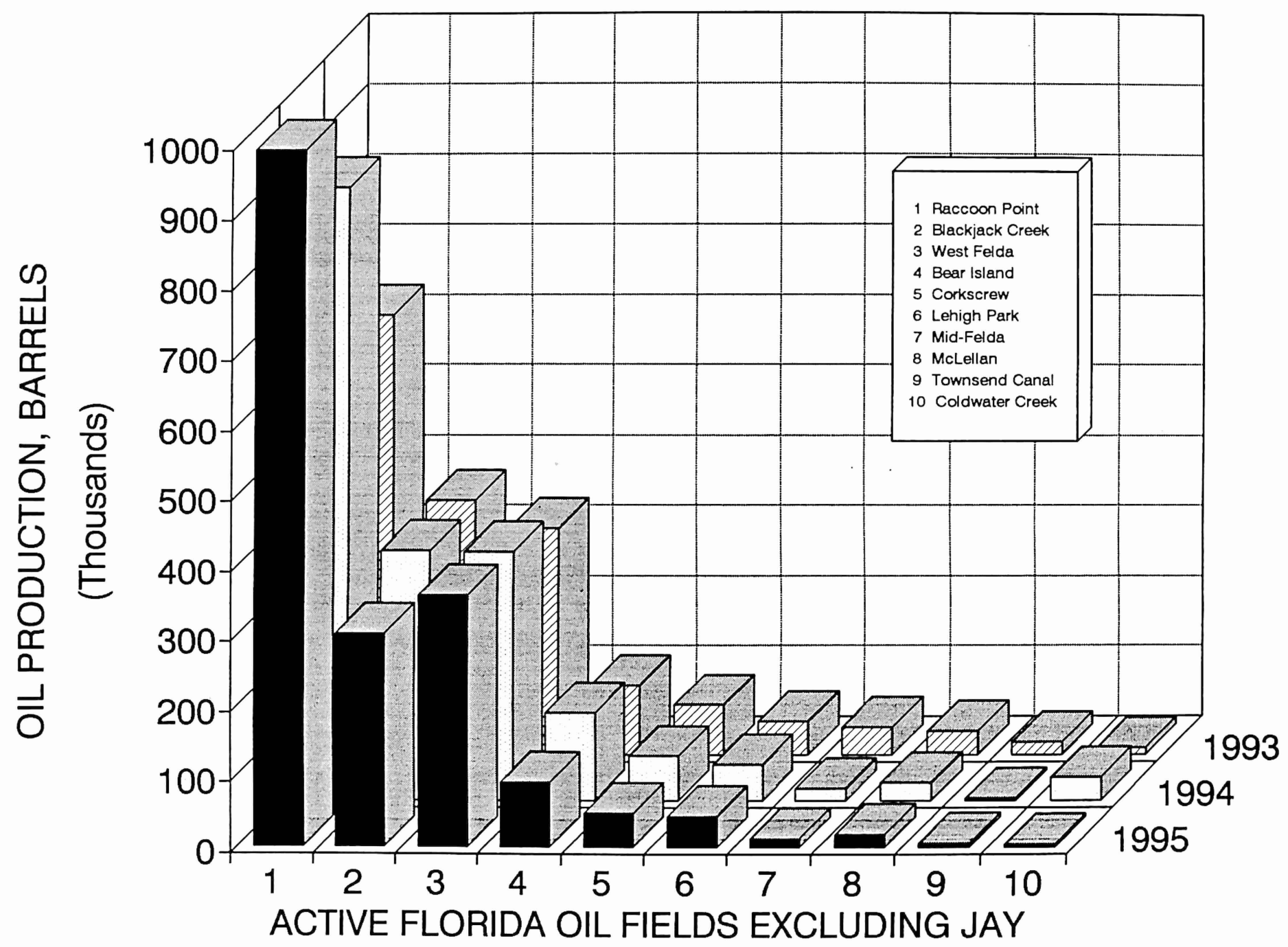

FGS020397

Figure 7. 1993, 1994, and 1995 oil production comparison for active Florida oil fields, excluding Jay field. 
respectively (Kim Straubinger, Accounting Systems Analyst, Florida Department of Revenue, written communication, 1996). Florida currently ranks nineteenth in crude oil production for the nation (World Oil, 1996).

\section{AND 1995 ONSHORE DRILLING ACTIVITY}

There were no new development wells completed during 1994; only one development well and its sidetrack were completed and abandoned in 1995 (Appendix 4). The original well was drilled in Mt. Carmel field in Santa Rosa County to a total depth of 15,077 feet below MSL and encountered the Smackover Formation at 14,871 feet below MSL and the Norphlet Sandstone at 15,125 feet below MSL. The well had an oil show, however, it was directionally drilled beyond the limits of the permitted irregular drilling unit, and thus had to be sidetracked to a permitted bottom hole location ( Jim LeBar, Petroleum Engineer, Florida Geological Survey, personal communication, 1996). The sidetrack well reached a total depth of 15,169 feet below MSL and drilled into the Smackover at 14,822 feet below MSL and the Norphlet at 15,076 feet below MSL. The well is in the process of being plugged and abandoned as a dry hole.

There were no exploratory wells drilled during 1994 and 1995, however, a well drilled in 1993 is included in this report because it was not reported on until 1994 and was excluded from the previous biennial report on petroleum activities (Lloyd, 1994). This well was drilled in Santa Rosa County, about four miles south of Blackjack Creek field (Appendix 5, Figure 8). The well was drilled to a total depth of 16,414 feet below MSL and encountered the Smackover Formation at about 15,959 feet below MSL and the Norphlet Sandstone at about 16,314 feet below MSL. There were no oil or gas shows in either the Smackover or the Norphlet and the well was plugged and abandoned as a dry hole.

\section{PROPOSED EVERGLADES EXPLORATION}

As discussed in the $1992 / 93$ report (Lloyd, 1994) on petroleum activity in Florida, Shell Western had proposed drilling a wildcat well on the Miccosukee Indian Reservation located within the Everglades in south Florida. At the end of 1993, the Bureau of Land Management was in the process of finalizing the Environmental Impact Statement (EIS) for the proposed exploration and an announcement of the federal "record of decision" was expected in summer 1994. On August 1, 1994 Shell Western officially withdrew its application to drill this exploratory well. Following the withdrawal, the Miccosukee Tribe announced that it intends to make an effort to find others interested in pursuing exploration of the Reservation's mineral potential. 
Information Circular 111

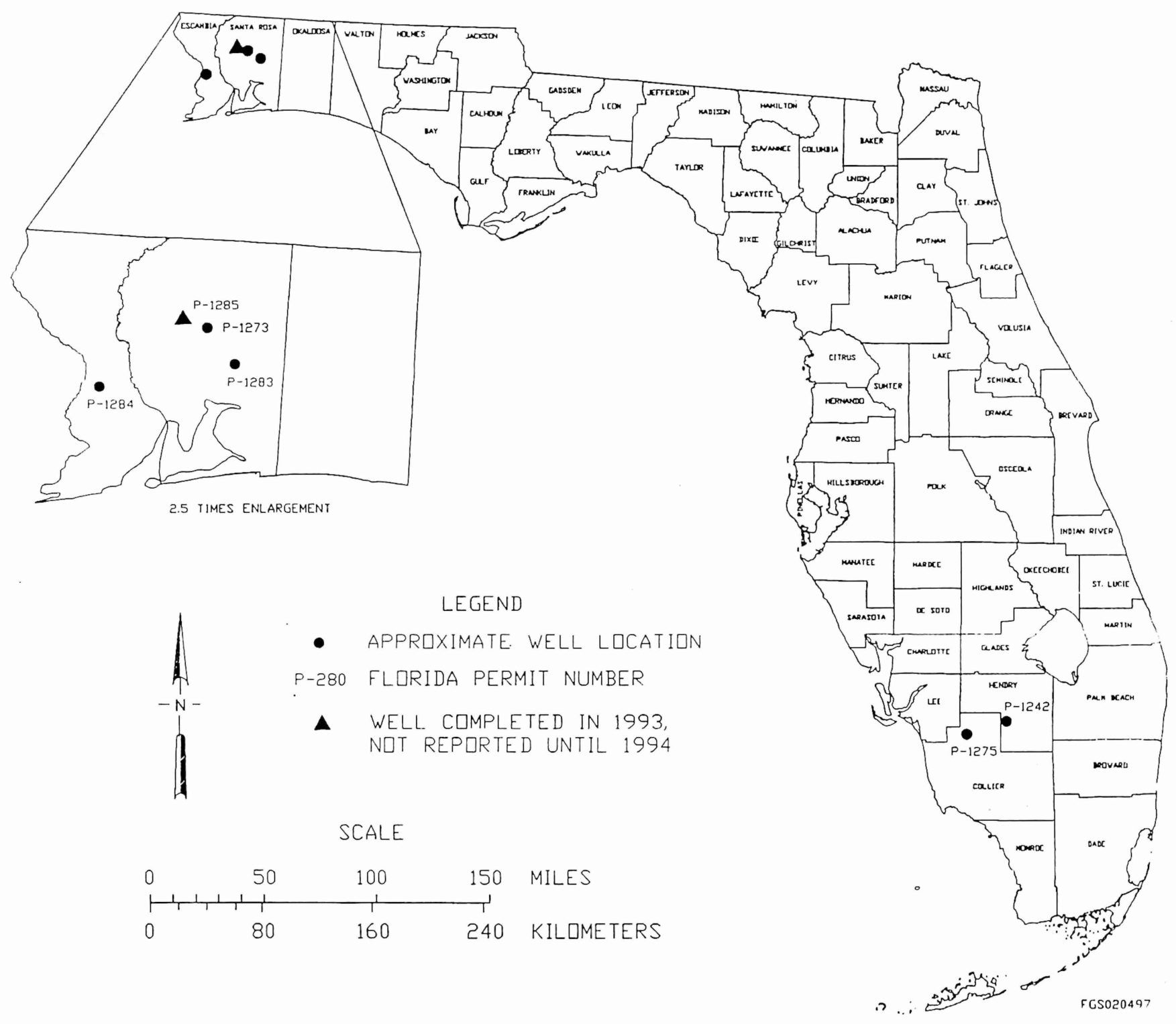

Figure 8. Updated map of 1992 and 1993 exploration wells. There were no new exploration wells drilled during 1994 or 1995. 
The drill site would have been on Indian land morth of Interstate 75 and just west of the L-28 canal in Broward County. The well was to be directionally drilled with the bottom of the hole located beneath one of south Florida's protected water conservation areas. The proposed location was about 12 milles northeast of Raccoon Point oil field which produces from the Cretaceous Sunniland Formation (Figure 2) at about 11,375 feet below mean sea level (MSL). Raccoon Point field is currently the southeastern-most producing field in the Sunniland trend (Figure 1).

\section{OFFSHORE DRILLING ACTIVITY}

State ownership of the continental shelf off Florida extends three miles into the Atlantic Ocean and about 10.4 miles (three marine leagues) into the Gulf of Mexico. The federal government controls resources beyond these state boundaries out to 200 miles. The Outer Continental Shelf (OCS) is a jurisdictional term that describes the offshore area which is under control of the federal government. "Federal waters," in this context, does not refer to ownership, but rather to responsibility (Johnson and Tucker, 1987).

\section{Exploratory Drilling in State Waters}

A total of 19 wells were drilled in Florida state waters between 1947 and 1983 (Appendix 6 and Figure 9). Effective July 1992, all drilling activity was prohibited in Florida state waters (Lloyd and Ragland, 1991), except for within pre-existing lease areas. Only one company, Coastal Petroleum, has pre-existing mineral-rights leases in Florida state waters. Coastal has held leases since 1947 for an area extending from Apalachicola Bay to Naples. The leases originally included all acreage within state waters extending out to 10.4 miles offshore. The leases were renegotiated in 1975, leaving Coastal with full lease rights from 7.4 to 10.4 miles and partial lease rights within the remaining portion of the original lease area. The outer lease area is shown as the offshore shaded area on Figure 10 (this coincides with the company's proposed geophysical exploration area).

The information obtained from the 19 wells that were drilled in state waters prior to the ban may be useful in future decisions concerning offshore exploration and development in federal waters. The 19 offshore wells tested three different potential oil horizons. Ten of the wells were within the south Florida Basin loff Charlotte and Lee Counties and off the Florida Keys, Monroe County, Figures 9 and 11) and targeted the Lower Cretaceous. The six wells drilled off the Florida panhandle sought to extend the onshore land offshore Alabama) Jurassic production (Figures 3 and 9). The remaining three wells drilled off the northern portion of the Gulf coast (Permits 304, 382 and 383) were Cretaceous or possibly Paleozoic tests (Applegate and Lloyd, 1985). 
Information Circular 111

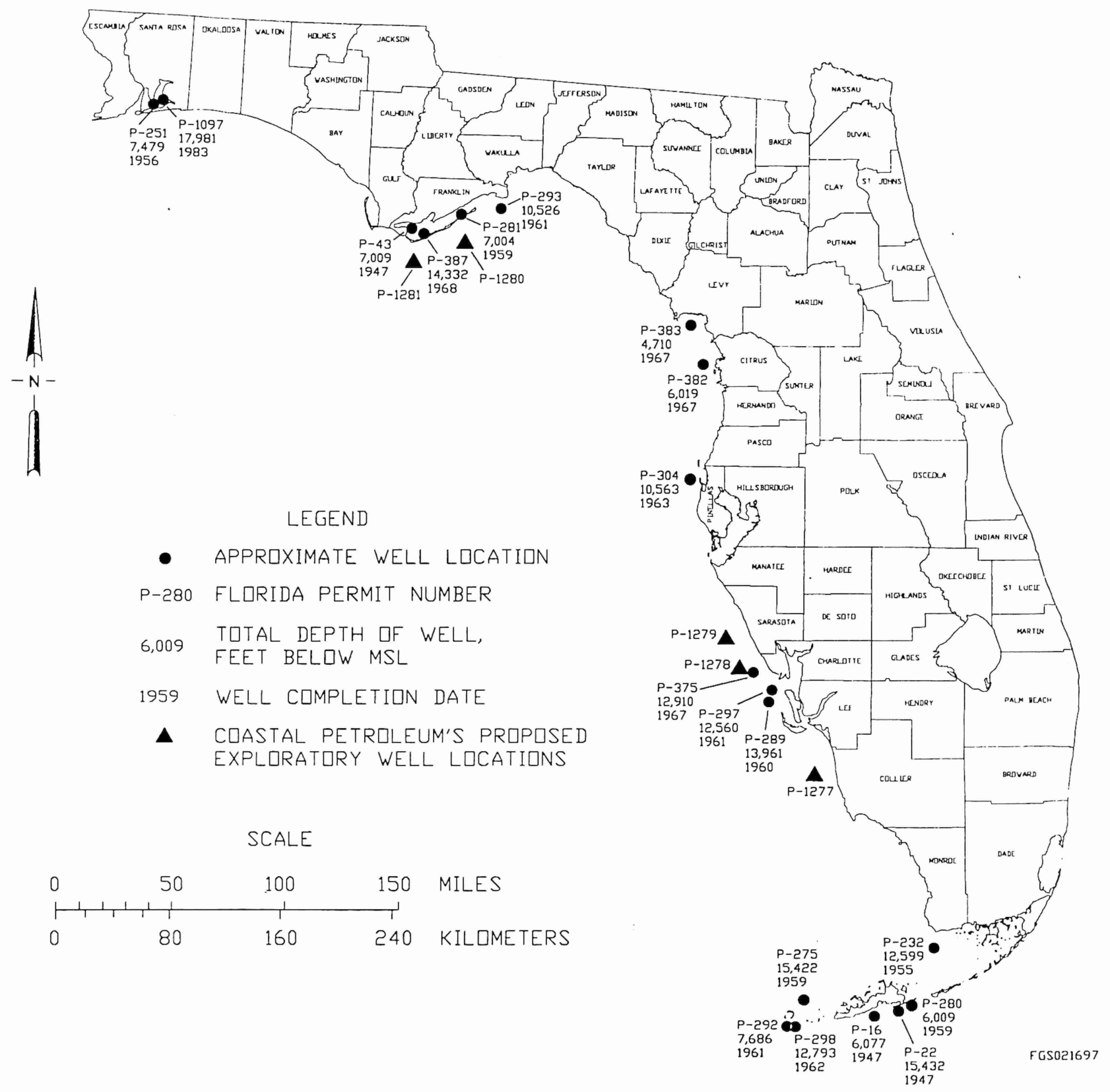

Figure 9. Exploration wells, Florida state waters, including Coastal Petroleum's proposed exploratory well locations. 


\section{Florida Geological Survey}

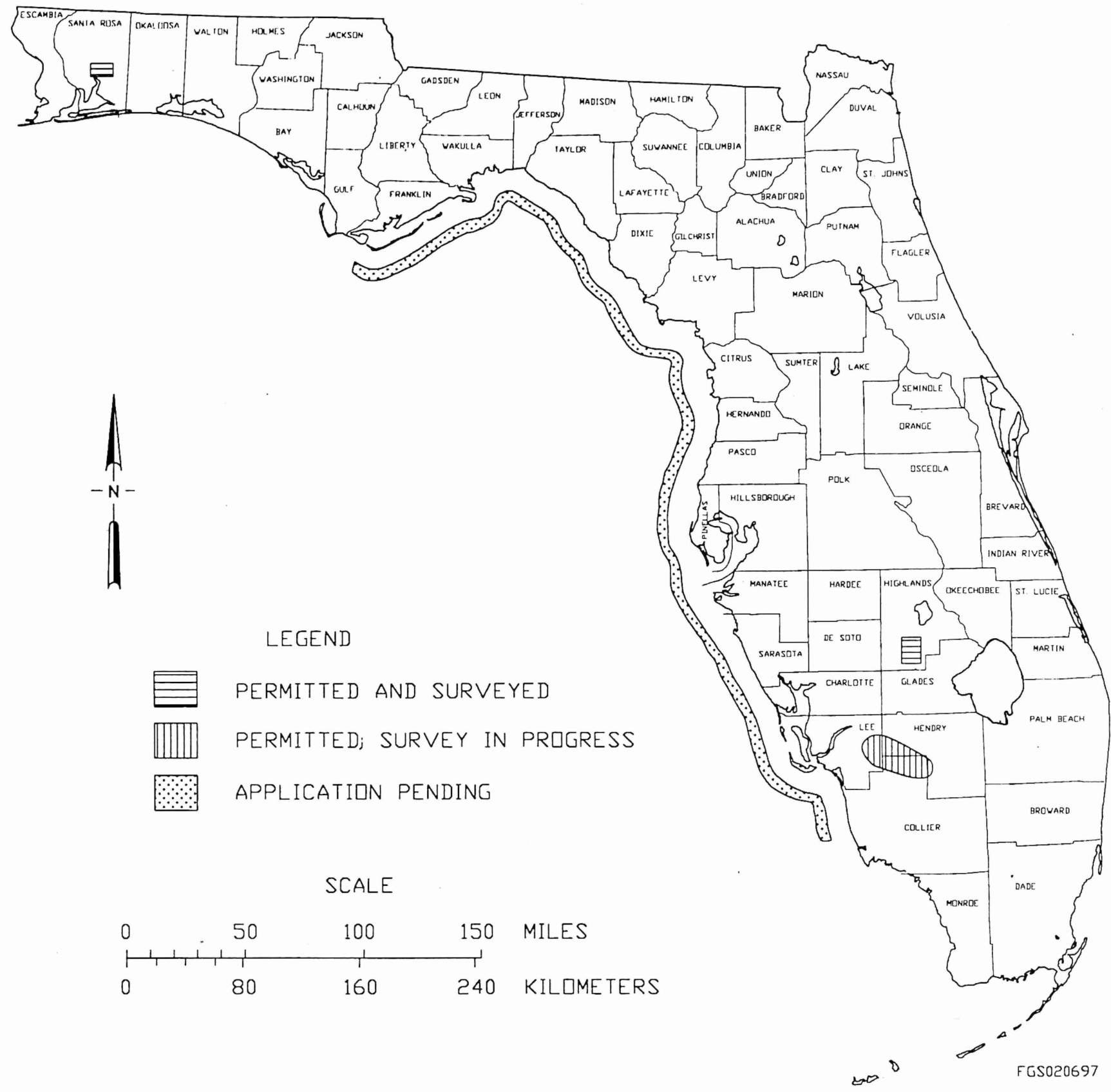

Figure 10. 1994 and 1995 geophysical exploration activity. 


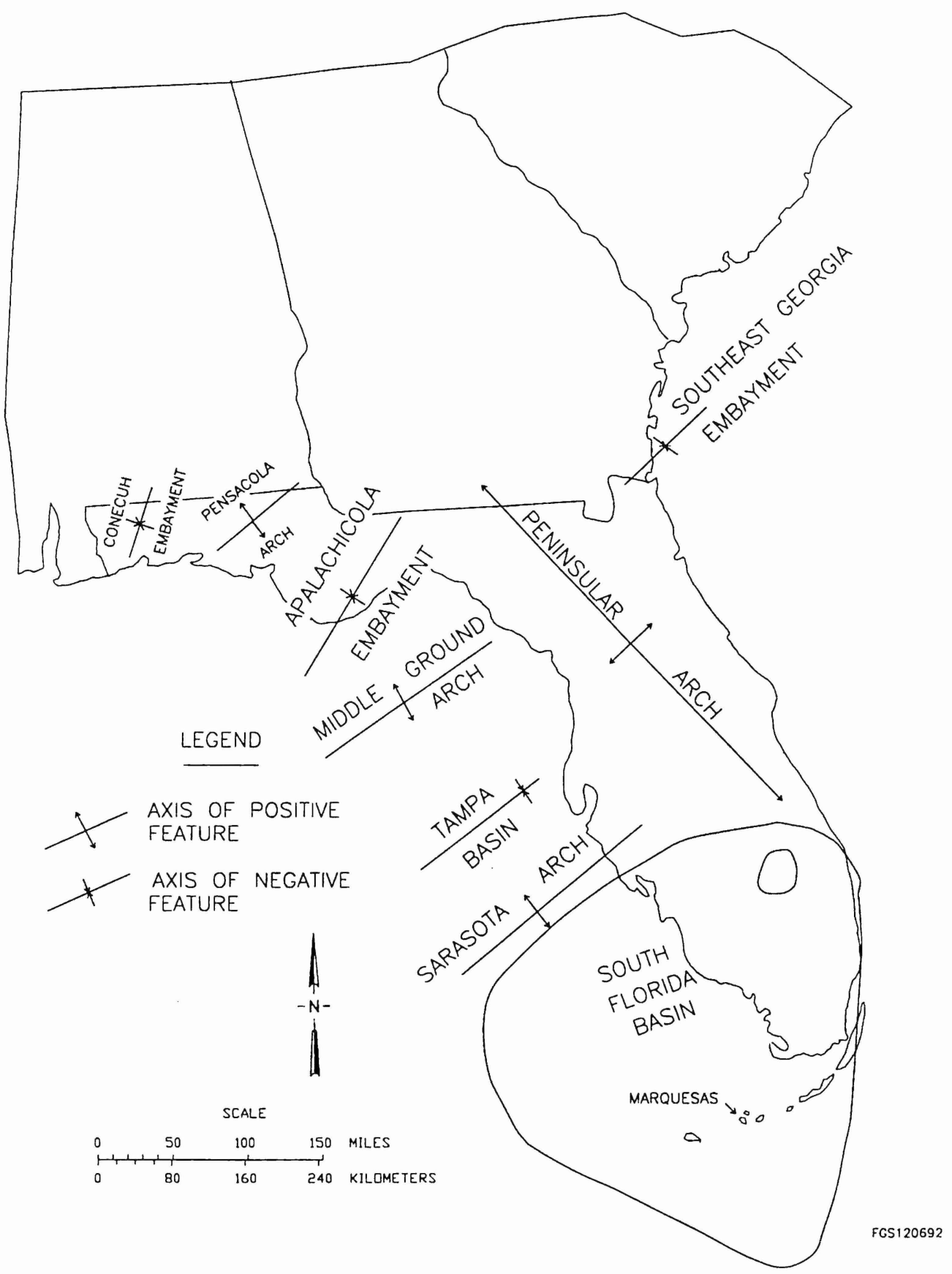

Figure 11. Mesozoic structural features in Florida and offshore (after Applegate, 1987). 
As shown in Appendix 6, only one of the wells drilled in state waters had a significant oil show. A drill stem test of the Gulf Oil-Florida State Lease 826-Y (Permit 275), located near the Marquesas Keys off Monroe County, recovered 15 barrels of $22^{\circ}$ A.P.I. gravity oil and 14.1 barrels of saltwater from the Lake Trafford (?) Formation. Another well, which was drilled in federal waters near the Marquesas, tested black saltwater in the Lake Trafford and Sunniland Formations and in the Brown Dolomite Zone of the Lehigh Acres Formation (Applegate and Lloyd, 1985).

\section{Exploratory Drilling in Federal Waters, Offshore Florida}

The first federal oil and gas lease sale off Florida was conducted in May, 1959 off the Florida Keys in what is now the Straits of Florida Planning Area. Ten additional OCS lease sales have occurred since then; seven in the Eastern Gulf of Mexico Planning Area and three in the South Atlantic Planning Area. There have been no sales in the Straits of Florida Planning Area off Florida since the 1959 sale. The last lease sale in the South Atlantic Planning Area off Florida was Sale 78 in July, 1983. Leases in the Eastern Planning Area are shown on Figure 12.

The two most recent lease sales off Florida were in the Eastern Planning Area. They were Sales 79 and 94, held in January, 1984 and January, 1985, respectively. Lease sales 79 and 94 are discussed in Applegate and Lloyd
(1985) and Lloyd and Applegate (1987).

The State of Florida has responded to the public's environmental concerns by objecting to future lease sales and exploration in federal waters off the Florida coast. In response to these concerns, the federal government excluded all areas originally proposed off the Florida coast in Eastern Planning Area Sale 116, held in November 1988. The federal government also agreed to pay nine oil companies a total of $\$ 200$ million for 73 leases off the Florida coast south of $26^{\circ}$ north latitude (Pulley Ridge and Howell Hook areas, Figure 12). This settlement permanently excludes the southwest Florida area from petroleum exploration, but does not affect the area off Florida's panhandle. Florida's Governor Lawton Chiles has said that he will continue to fight for protection of the remainder of the Florida Gulf coastline and is pressing for a permanent 100-mile wide buffer zone around the entire Florida coastline. The 100-mile buffer will be excluded from the next Minerals Management Service five-year (1997-2002) lease plan.

At the close of 1995, Chevron was in the process of drilling an exploratory well in the Destin Dome area, 26 miles south of Pensacola, Florida (Block 57, Figure 12, map location code 40). Chevron has successfully drilled two producible Norphlet wells in this area (Block 56, Figure 12, map location code 32) (Lloyd, 1992). In addition to the two Chevron wells, the Amoco-8338 well, 
which was completed in Destin Dome block 111 in 1987, was also a Norphlet discovery described by Gould (1989) as a producible field (Figure 12, map location code 31). This was the first commercial discovery in the Eastern Gulf of Mexico Planning Area (Gould, 1989). These discoveries extend the offshore Norphlet gas trend (which is highly productive off Mobile Bay, Alabama) seaward and eastward from the Mobile map area of the Central Gulf of Mexico Planning Area, offshore Alabama, into the Florida offshore.

In addition to these Norphlet gas discoveries, another Amoco well drilled in DeSoto Canyon, Block 133 (Figure 12, map location code 38) was apparently judged to be producible from a Miocene fan deposit (depth to producing horizon is not known). The location is approximately 100 miles south of the Florida-Alabama border; it is not known whether this will spur further interest in federal waters off Florida in this area.

\section{AND 1995 GEOPHYSICAL EXPLORATION ACTIVITY}

Geophysical exploration during 1994 and 1995 included 102 miles of gravity survey and 42.8 miles of seismic survey. Appendix 7 summarizes the data for the three permits covering these areas. The gravity survey was completed in Highlands County (Figure 10) in an area northeast of the Sunniland producing trend. Of the 42.8 miles of seismic survey, 22.5 miles were located in Santa Rosa County southeast of the known Smackover production. The remaining 20.3 miles were located in south Florida in Lee, Hendry and Collier Counties within the Sunniland producing area.

An additional permit application was pending at the end of 1995 which included an extensive offshore area. This application includes seismic, gravity, and magnetic surveys of a dense grid off of Florida's Gulf coast extending from offshore of Apalachicola, Franklin County to offshore of Naples, Collier County (Figure 10). The permit application is incomplete at this time and does not provide seismic mileage or gravity/magnetic survey details. The same area was permitted for exploration in July 1992, however, the permit expired in July 1993 with minimal activity (magnetometer survey off Franklin and Gulf Counties) reported to the Department of Environmental Protection.

\section{FLORIDA OIL FIELD DESCRIPTIONS}

Applegate and Lloyd (1985) and Lloyd (1991) provide a brief history of each of Florida's oil fields including discovery data, geologic information, and production totals. Structure maps were presented whenever possible. These publications are now out-ofprint; therefore, this information is summarized again and presented in this report. Fields are discussed in approximate geographic order from 
Florida Geological Survey

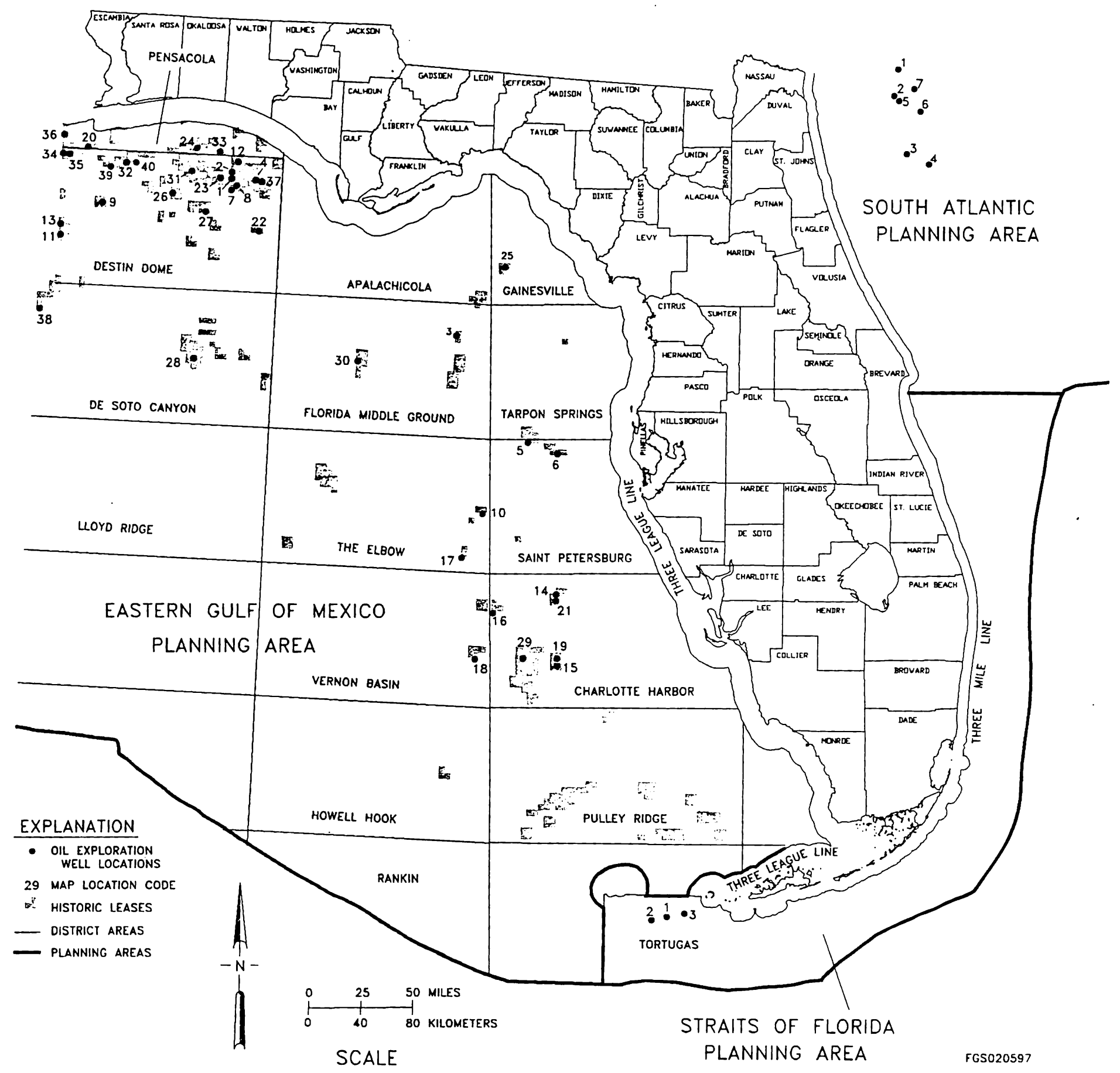

Figure 12. Exploration wells and historic leases, federal waters, offshore Florida (Gould, 1989). 
Information Circular 111

MAP LOCATION CODES AND WELL DATA FOR FIGURE 12

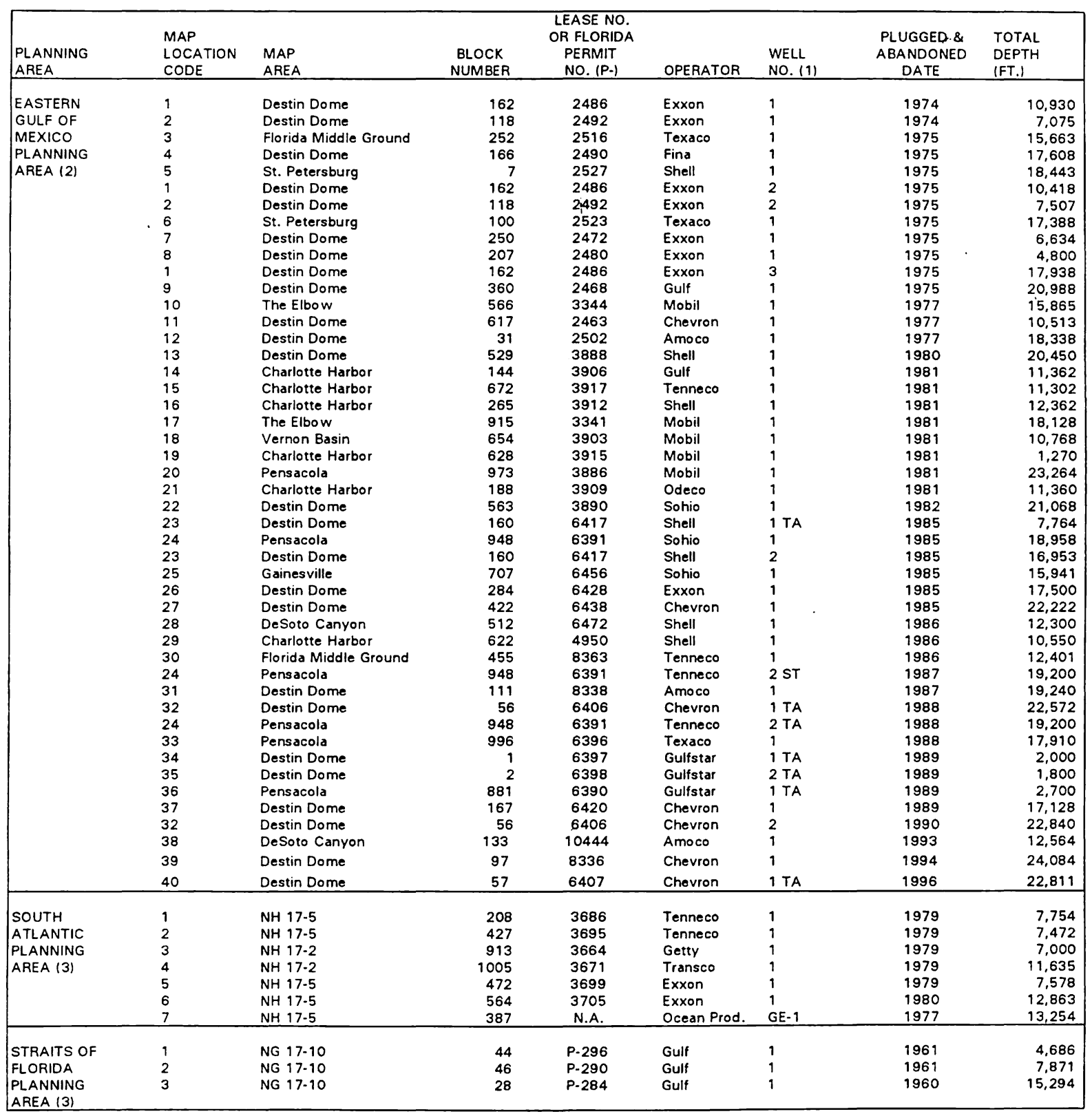

1. $T A=$ Temporarily Abandoned; $S T=$ Sidetrack Well.

2. Data from Gould, 1989; Andy Petty, MMS, personal communication, 1992 and 1996; S. M. Fury, Chevron, personal communication, 1996.

3. Data from Karpas and Gould, 1990. 
north to south and west to east (Figures 1 and 3). More detailed information is presented for the five oil fields discovered since 1985. These are Bluff Springs, McDavid, Coldwater Creek, and McLellan fields in north Florida and Corkscrew field in south Florida.

\section{North Florida Oil Field Summaries}

\section{INTRODUCTION}

Production in north Florida began with the discovery of Jay field in June, 1970. There are now eight panhandle oil fields located in Escambia and Santa Rosa Counties, Florida (Figure 3). Five fields are active and three are plugged and abandoned. Production is from Upper Jurassic Smackover Formation carbonates and Norphlet Sandstone sands (Figure 4).

Jay field is located within a trend which extends through Escambia and Santa Rosa Counties in Florida, and Escambia County, Alabama. Other fields within the trend include $\mathrm{Mt}$. Carmel, Coldwater Creek, and Blackjack Creek fields in Florida and Fanny Church, Flomaton, and Big Escambia Creek fields in Alabama. The fields are located along a normal fault complex which rims the Gulf Coast through Alabama, Mississippi, Louisiana, Arkansas, and Texas (Moore, 1984).

Bluff Springs and McDavid fields are located west and southwest of the Jay trend in an area known to be underlain by Louann Salt, with seismic studies indicating salt-induced fault structures in the overlying formations (Lloyd and Applegate, 1987). The remaining two north Florida oil fields, McLellan and Sweetwater Creek, are located east of the Jay trend, near the approximate updip limits of the Smackover Formation (Lloyd, 1989; Applegate et al., 1978; Ottman et al., 1973 and 1976) and could be the result of stratigraphic pinchouts. They are also located within the area known to be underlain by the Louann Salt and may have salt-related trap structures. Current data does not reveal which trapping mechanism produced the Smackover reservoirs for these fields.

\section{BLUFF SPRINGS FIELD}

Bluff Springs field was discovered on March 25, 1984 and was plugged and abandoned in 1991 after producing a total of 242,000 barrels of oil solely from the discovery well (Appendices 1 and 2). The discovery well, the Stone Petroleum Corp. St. Regis Paper Co. number 29-4 (permit 1125), was a rank wildcat located in Section 29, Township 5 North, Range 31 West, Escambia County. It is approximately 10 miles west-southwest of Jay field and approximately four miles southeast of the nearest previously drilled wildcat, permit 1177 (Figures 3 and 13). This area, west and southwest of Jay, is known to be underlain by Louann Salt, with seismic studies indicating saltinduced fault structures in the overlying formations (Lloyd and Applegate, 


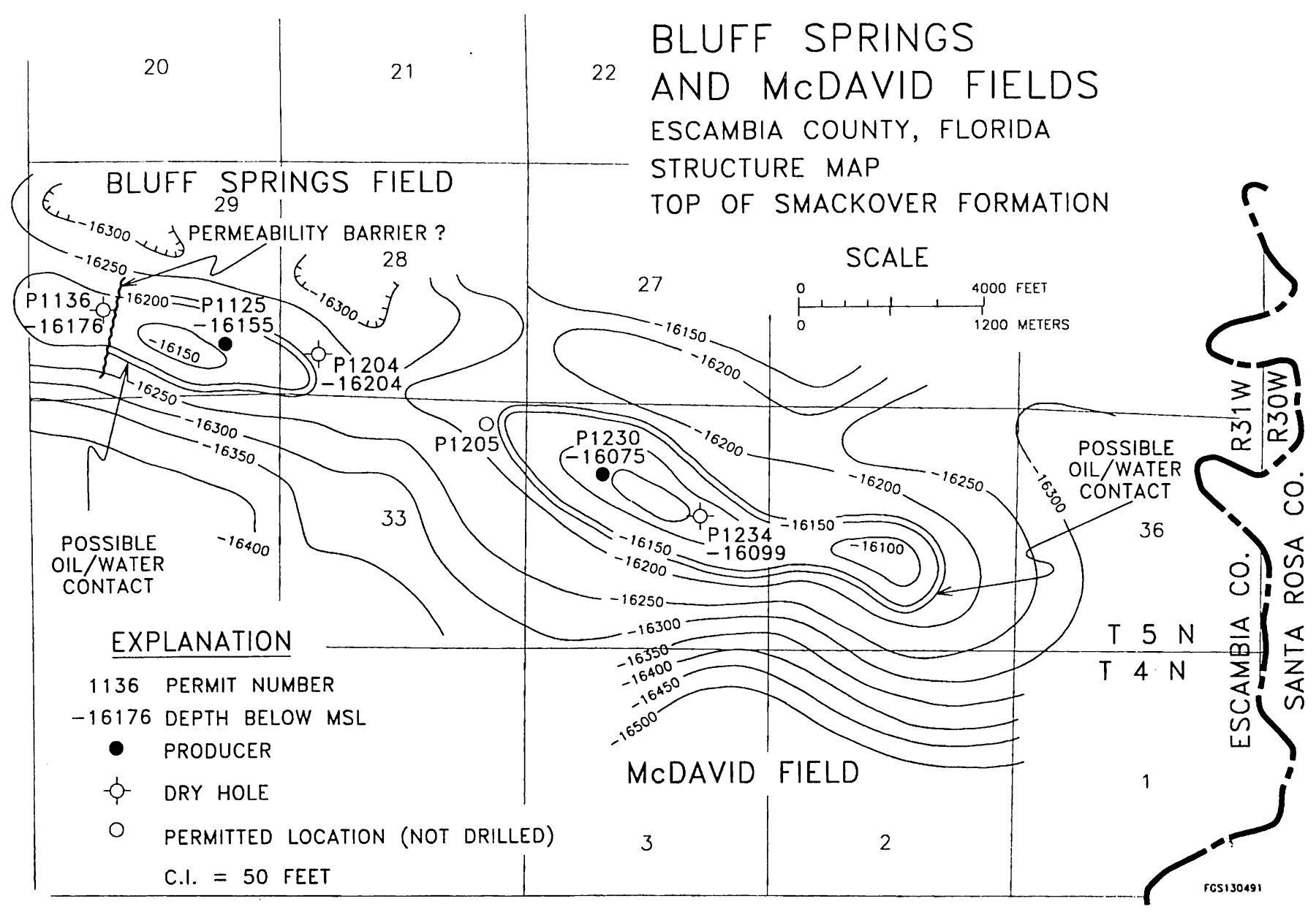

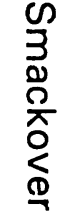


1987). Seismic data has been interpreted by Hughes Eastern Corporation (1988) to indicate several small structures in a northwest-tosoutheast trend in this specific area.

The discovery well produced 477 barrels of oil and 170 barrels of saltwater per day. Oil gravity was $57.0^{\circ}$ A.P.l. Production was from Jurassic-age Smackover Formation dolostones from $-16,154$ to $-16,161$ feet MSL. These dolostones are dark brownish-gray to brownish-black, fine grained, microcrystalline, and show evidence of recrystallization from originally oolitic and possibly pelletal facies (Lloyd, 1986; Lloyd and Applegate, 1987).

The offset well, permit 1136 (Stone Petroleum Corporation - St. Regis Paper Company number 29-3) was drilled about one-half mile northwest of the discovery well (Figure 13). The Smackover Formation was encountered at $-16,171$ feet MSL, structurally 17 feet lower than in the discovery well (Figure 14). The well produced only saltwater from two thin zones $(-16,182$ to $-16,185$ feet MSL and $-16,192$ to $-16,195$ feet MSL; Figure 14l within the upper Smackover. Core analysis by Location Sample Service, Inc. (LSS), Jackson, Mississippi, yielded mean porosity estimates for these zones of 11.4 and 8.4 percent, respectively. LSS found a trace of oil in one sample at $-16,185$ feet MSL. This well may be located too low on the structure. Alternatively, as shown on the structure map (Figure 13) drawn by Hughes Eastern
Corporation (1988; based on geophysical and well data), Hughes believes there may be a permeability barrier between the discovery well and this well.

Ownership of the discovery well transferred to Hughes Eastern Corporation in 1985. Permits were issued to Hughes Eastern to drill two additional offsets, one east and one southeast of the discovery well (permits 1204 and 1205, Figure 13). Permit 1204 was completed in August 1986. The Smackover was again found at a structurally lower position (Figure 14), this time 44 feet lower. Two zones of saltwater production were also encountered $(-16,208$ to $-16,211$ feet MSL and $-16,215$ to $-16,233$ feet MSL; Figure 14). LSS core analysis yielded mean porosity estimates of 23.9 and 13.6 percent, respectively, and no indications of oil. As interpreted by Hughes Eastern Corporation (1988) (Figure 13), the Smackover in this well is below the probable oil-water contact. The third offset, permit 1205, was not drilled. The location for permit 1205 is actually closer to McDavid field (discussed below) and is outside the potential productive limits drawn by Hughes Eastern Corporation (1988) (Figure 13).

\section{McDAVID FIELD}

McDavid field was discovered on June 14, 1988 with the first production test of the discovery well, the Hughes Eastern Corp. Walker-Baley number 34-2 (permit 1230, Appendix 


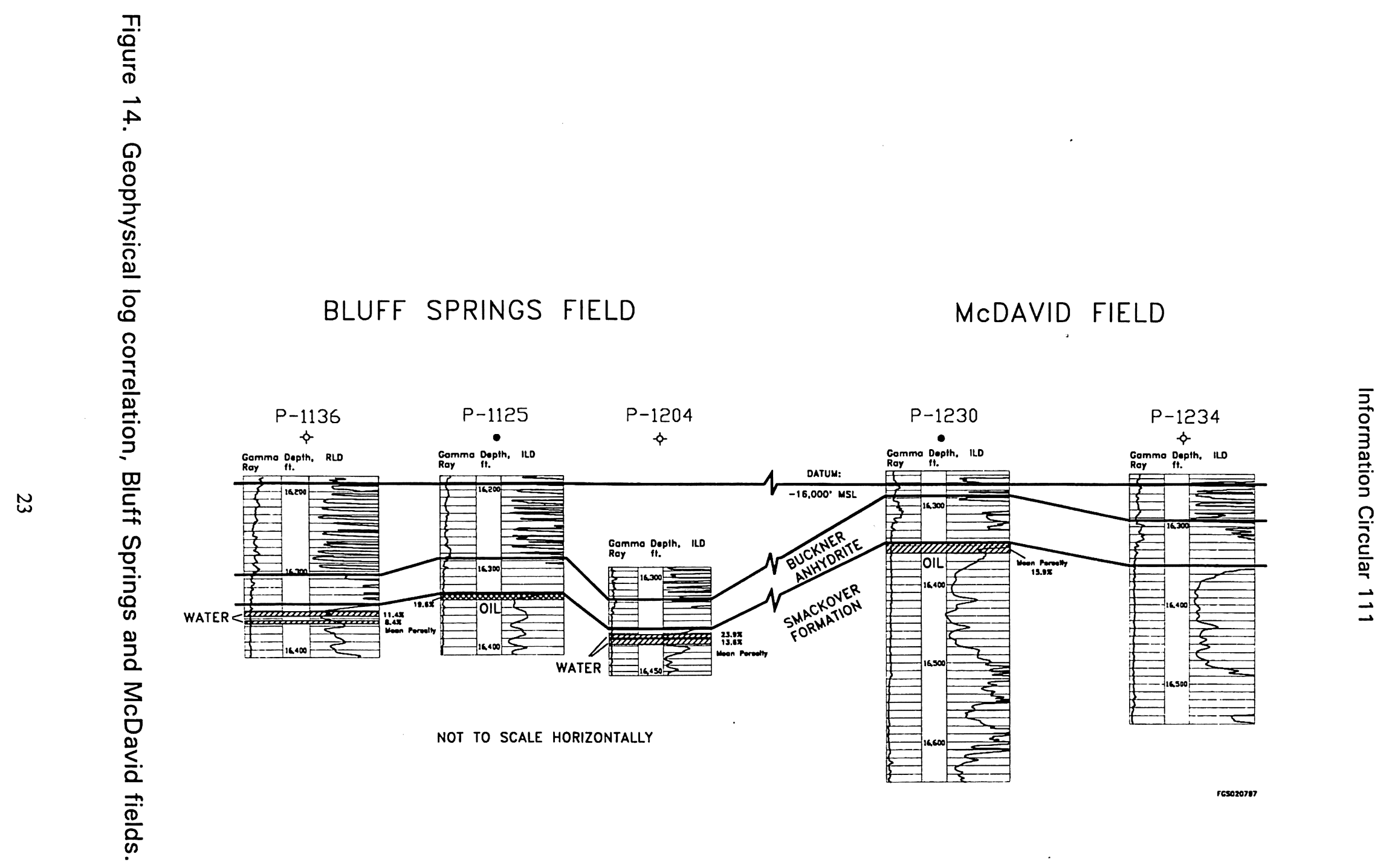


1). This field was also plugged and abandoned in 1991 after producing solely from its discovery well. McDavid field produced a total of 150,000 barrels of oil (Appendix 2). The discovery well is located in Section 34, Township 5 North, Range 31 West, Escambia County (Appendix 1). It is about one and one-half miles southeast of the Bluff Springs discovery well (Figures 3 and 13). As discussed above for Bluff Springs field, this area, west and southwest of Jay, is known to be underlain by Louann Salt, with seismic studies indicating salt-induced fault structures in the overlying formations (Lloyd and Applegate, 1987). Seismic data has been interpreted by Hughes Petroleum Corp. (1988) (Figure 13) to indicate several small structures in a northwest to southeast trend in this specific area.

The discovery well produced 235 barrels of oil per day and no saltwater. Oil gravity was $53.8^{\circ}$ A.P.I. Production was from Jurassic-age Smackover Formation dolostones from $-16,075$ to $-16,089$ feet MSL. These dolostones were described by LSS as gray to dark gray, sucrosic to granular, with poor to fair porosity and permeability. Examination of core chips with a binocular microscope concurs with this description. Core analysis by LSS yielded a mean porosity estimate of 15.9 percent for this zone. Geophysical log analyses by Charles Tootle (Professional Engineer, Florida Geological Survey, personal communication, 1988) yielded a mean porosity estimate of 12.8 percent, an original oil in place estimate of $4,987,347$ barrels, and a recoverable oil estimate of 498,736 barrels (Appendix 8).

The first offset, permit 1234 (Hughes Eastern Corporation - Jones Estate number 34-1) is located about one-half mile southeast of the discovery well (Figure 13). The offset was completed in June 1989. The Smackover Formation was encountered at $-16,099$ feet MSL, structurally 24 feet lower than in the discovery well (Figure 14). The structure map (Figure 13) was drawn prior to the time this well was drilled. As shown on the map, Hughes Eastern Corporation expected to encounter the Smackover at about $-16,050$ feet MSL in this well. Based on the actual depth $(-16,099$ feet MSL), the McDavid structure is probably smaller than that shown. The productive limit expected by Hughes is still below this depth (at about $-16,200$ feet, Figure 13); however, analysis of geophysical logs from this well indicate that the oil-water contact may actually be at about -16,102 feet MSL (Joel Duncan, professional geologist, Florida Geological Survey, personal communication, 1991). In addition, production from the discovery well appears to have peaked around December 1988 and may have depleted this small structure enough to move the potential productive limits above the level of the Smackover in the offset (Figure 15) (Joel Duncan, professional geologist, Florida Geological Survey, personal communication, 1991). 
Information Circular 111

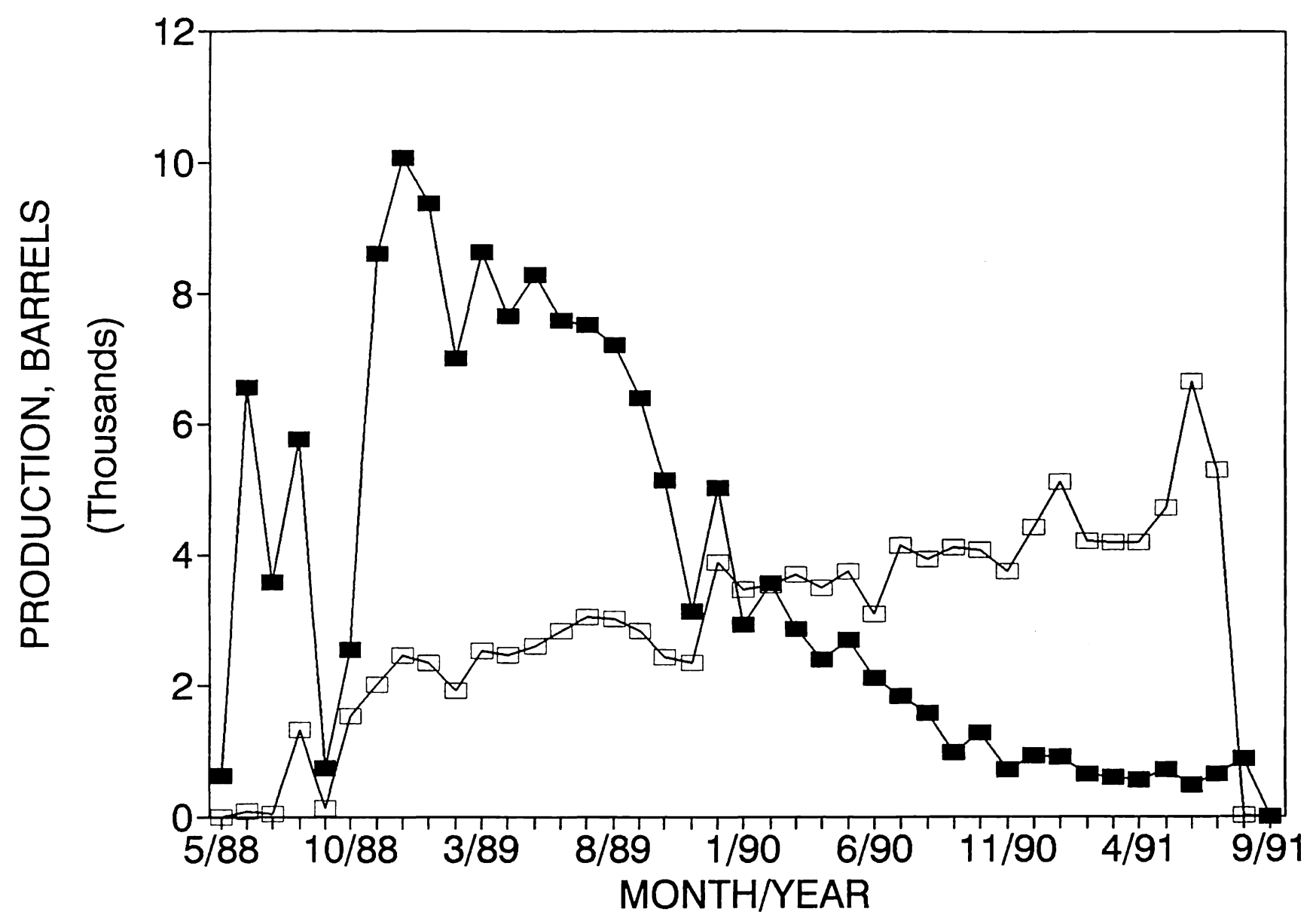

$\rightarrow$ Oil $\square$ Water

FGS160491

Figure 15. McDavid field production curve. 


\section{JAY FIELD}

Jay field was discovered in June, 1970, by the drilling of the Humble St. Regis number 1 (permit 417) in Section 43, Township 5 North, Range 29 West, Santa Rosa County (Figures 3 and 16 and Appendix 1). The well produced from the Smackover Formation from $-15,264$ to $-15,318$ feet MSL. The initial production test yielded 1,712 barrels of $50.7^{\circ}$ A.P.I. gravity oil and 23 barrels of saltwater per day.

Jay field is located within the "Jay trend" of Escambia and Santa Rosa Counties, Florida and Escambia County, Alabama (discussed in north Florida oil fields introduction above). The northern extension of Jay, in Escambia County, Alabama, is the Little Escambia Creek (LEC) field. Oil accumulation at Jay is within an asymmetric anticline with the fault complex forming the eastern barrier to oil migration (Figure 16) (Applegate and Lloyd, 1985).

The northern limit of Jay field is a porosity barrier in Alabama where the lithology changes from porous dolostone to dense, micritic limestone. The porosity at Jay field is due to dolomitization of the pelletal grainstones in the upper, regressive section of the Smackover Formation. Dolomitization, fresh water leaching, and an anhydrite cap rock (Buckner Member of the Haynesville Formation, Figure 4) have formed a complex, extensive reservoir. Numerous analyses of the Jay area Smackover Formation, including comparisons with modern carbonate environments, have been made in attempts to understand this complex reservoir (Ottman et al., 1973 and 1976; Sigsby, 1976; Mancini and Benson, 1980; Lomando et al., 1981; Vinet, 1984; Moore, 1984; Bradford, 1984; Lloyd et al., 1986).

Despite the complexity of the Jay field Smackover Formation reservoir, exploration and development of the field have been extremely successful. Core analyses were combined with bottom hole pressure data, porosity log information, and other geologic data to arrive at a highly successful reservoir management program (Shirer et al., 1978; Langston et al., 1981; Langston and Shirer, 1985).

As of December 1995, Jay field was producing from a total of 51 wells, 32 wells were temporarily shutin, and there were 28 injection wells (Appendix 3). Cumulative production for Jay field, as of the end of 1995, was $387,815,585$ barrels of oil (Appendix 2).

\section{COLDWATER CREEK FIELD}

Coldwater Creek field was discovered on June 4, 1988. The discovery well was a reentry of a Smackover wildcat. The original permit was issued to Inexco Oil Company (permit 1173). The location is about two miles east of the southern portion of Jay field in Section 26, Township 5 North, Range 29 West, Santa Rosa County (Figure 3 ). Inexco began drilling 


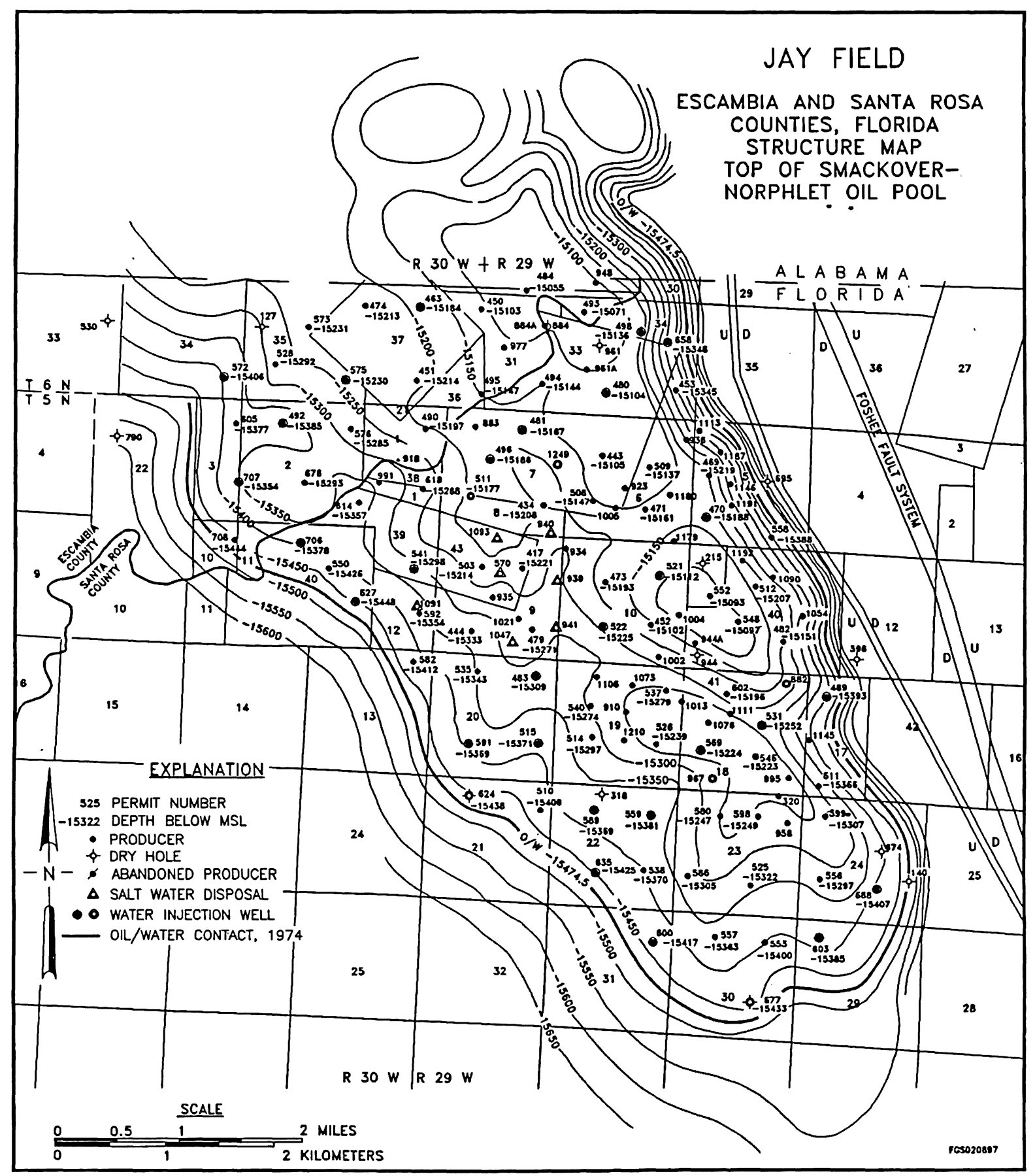

Figure 16. Jay field structure map, top of Smackover Formation (after Jay-LEC Fields Unit Geological Committee, 1974). 
in November, 1985. They drilled the well to a total depth of $-15,407$ feet MSL, logged the well, and recommended plugging and abandonment.

The top of the Smackover Formation had been encountered at $-14,969$ feet MSL; the Norphlet Sandstone at $-15,331$ feet MSL. Side wall core analyses by Location Sample Service, Inc. (Jackson, Mississippi) indicated a potential oil productive zone from $-14,985$ to $-15,016$ feet MSL. Mean porosity of the zone was about 14.8 percent. Analysis of the same interval by Charles Tootle yielded a mean porosity of about 12 percent, an original oil in place estimate of $2,080,107$ barrels, and a recoverable oil estimate of 312,016 barrels (Appendix 8).

Louisiana Land and Exploration Company (LL\&E) took over operations on January 10, 1986 and plugged and abandoned the well. Bruxoil, Inc. then took over responsibility for the well. They conducted a geophysical survey across the area (geophysical permit G70-86; see Lloyd, 1989). The stated purpose was to determine whether to reenter the existing well or drill at a new location. They decided not to reenter the well and have not submitted any permit applications to drill in the vicinity.

In 1987, Red Rock Oil and Minerals Corporation received permit 1220 (Appendix 1) to reenter the well. They completed redrilling on May 24, 1987 and ran the first production test on June 4, 1988. This test yielded 152 barrels per day of $46.5^{\circ}$ A.P.I. gravity oil and 280 barrels per day of saltwater. In a retest on December 27 , 1988, the well flowed 259 barrels per day of $46.5^{\circ}$ A.P.I. gravity oil with no saltwater production. Production is from the zone discussed above, from $-14,984$ to $-15,006$ feet MSL in the Smackover Formation. Judging from the field's location within the Jay trend, it appears that reservoir formation may have been structurally related to the Foshee Fault System; however, a single well does not yield sufficient information to test this hypothesis.

No additional wells have been drilled at Coldwater Creek field. Cumulative production, as of December 1995 from Coldwater Creek field was 80,068 barrels of oil from this single well (Appendix 2).

\section{BLACKJACK CREEK FIELD}

The Blackjack Creek field discovery well was the Humble Oil and Refining Company - St. Regis Paper Company number 13-3 well (permit 523) drilled in Section 13, Township 4 North, Range 29 West, Santa Rosa County, about eight miles southeast of Jay field (Appendix 1, Figures 3 and 17). The well was completed February 14,1972 , as a producer in the Norphlet Sandstone from $-15,965$ to $-15,975$ feet MSL. Initial production was 371 barrels of $51.3^{\circ}$ A.P.I. gravity oil and 4.5 barrels of saltwater per day. Due to limited productivity and water production from the Norphlet 


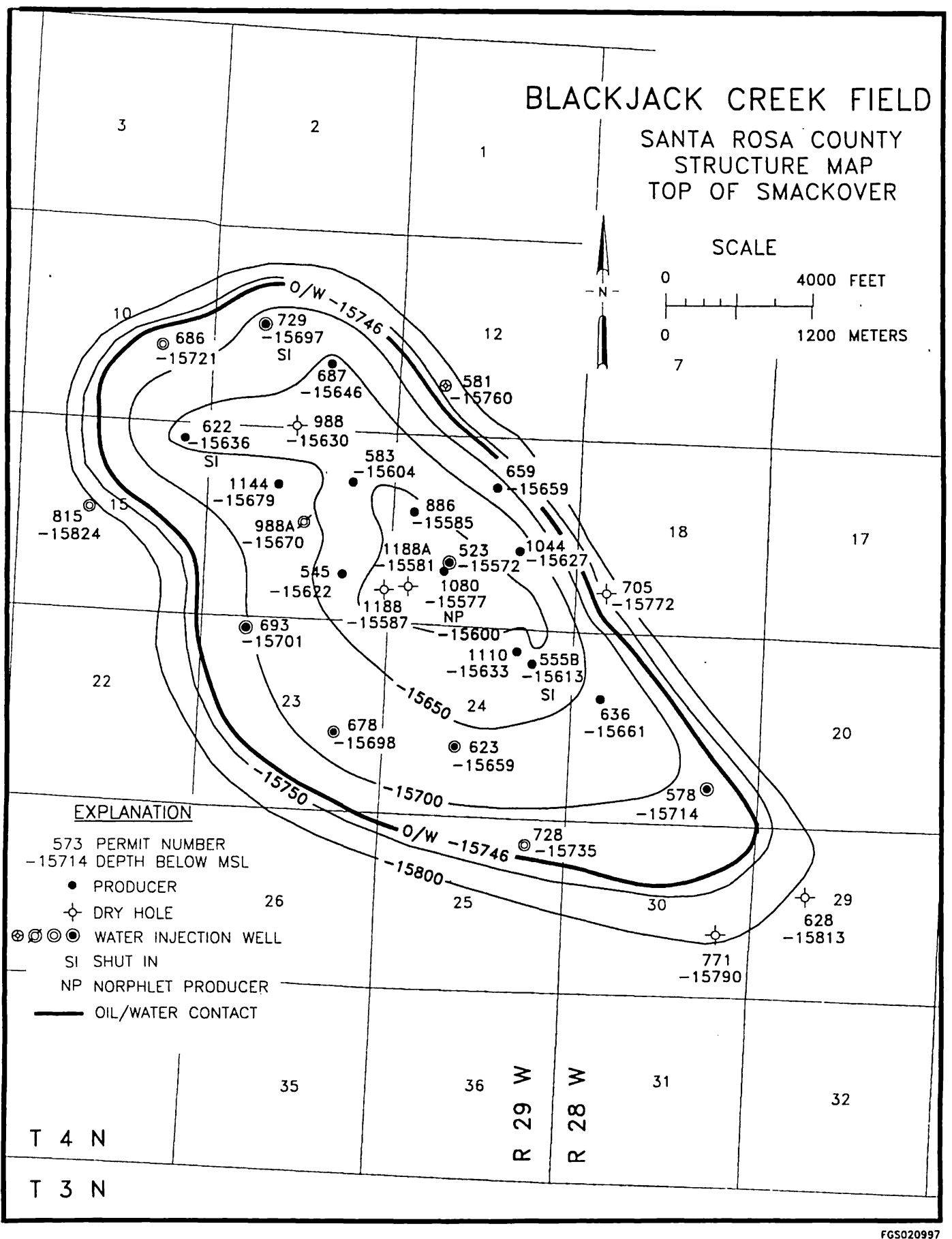

Figure 17. Blackjack Creek field structure map, top of Smackover Formation (after Blackjack Creek Geological Committee, 1974, modified by Jim LeBar, Petroleum Engineer, Florida Geological Survey, personal communication, 1996). 
Sandstone, the well was recompleted as a Smackover Formation producer from $-15,633$ to $-15,743$ feet MSL. The initial production test from the Smackover, on January 22, 1975, yielded 1,428 barrels of $51.2^{\circ}$ A.P.I. gravity oil and no saltwater.

Blackjack Creek field now produces primarily from oolitic dolostones of the Smackover Formation (Applegate and Lloyd, 1985) A single well, permit 1080 (Figure 17), produces from the Norphlet Sandstone. The trapping structure is an anticline located on the downthrown, southwest side of the regional Foshee Fault System (Figure 17). Similar to Jay field, Blackjack Creek has been carefully cored and analyzed to achieve a successful reservoir management and development program.

Cumulative production for Blackjack Creek field was 56,805,223 barrels through December 1995 (Appendix 2) Of this total production, 578,533 barrels were produced from the Norphlet Sandstone and $56,226,690$ barrels were produced from the Smackover Formation. Through January 1996, 18 producing wells and seven dry holes had been drilled at Blackjack Creek. Ten wells were actively being produced as of December 1995 (Appendix 3).

\section{MT. CARMEL FIELD}

Mt. Carmel field was discovered in December 1971 by LL\&E. The discovery well was the LL\&E - Finley Heirs number 39-3 (permit 504), located about one mile east of Jay field in Section 39, Township 5 North, Range 29 West, Santa Rosa County (Appendix 1, Figures 3 and 18). Initial production was 1,440 barrels of $47^{\circ}$ A.P.I. gravity oil per day with no saltwater.

Mt. Carmel field is separated from Jay field by the Foshee Fault System (Figure 18) Mt. Carmel field produces both oil and gas from the Smackover Formation and the Norphlet Sandstone. Complex reservoir geometry has apparently made development of this field more difficult. As of January 1996, three producing wells and 12 dry holes had been drilled at Mt. Carmel field.

There is currently one producing well in the Mt. Carmel field. As of the end of 1995, the field had produced $4,770,745$ barrels of oil (Appendix 2).

\section{MCLELLAN FIELD}

McLellan field was discovered on February 15, 1986, with the initial testing of the Exxon Corporation State of Florida number 33-1 (permit 1194, Appendix 1, Figures 3 and 19). The well is located about 3.25 miles north of the abandoned Sweetwater Creek field in Section 33, Township 6 North, Range 26 West, Santa Rosa County.

An initial flowing test of the discovery well produced 152 barrels of $41^{\circ}$ A.P.I. gravity oil per day and no saltwater. Production is from Smackover Formation dolostones from $-13,827$ to $-13,845$ feet MSL (Figure 


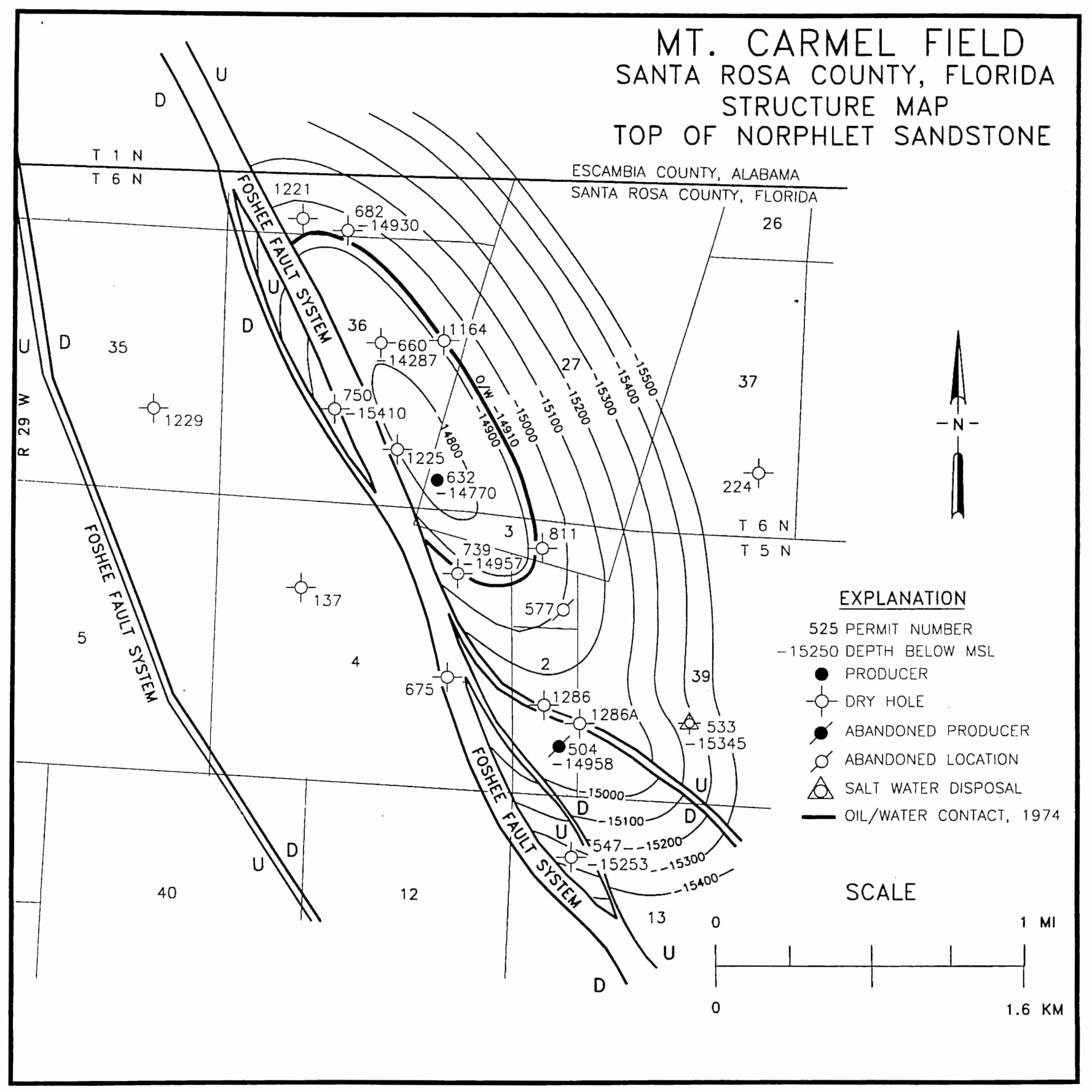

FCS021097

Figure 18. Mt. Carmel field structure map, top of Norphlet Sandstone (after Miller, 1974). 
Florida Geological Survey

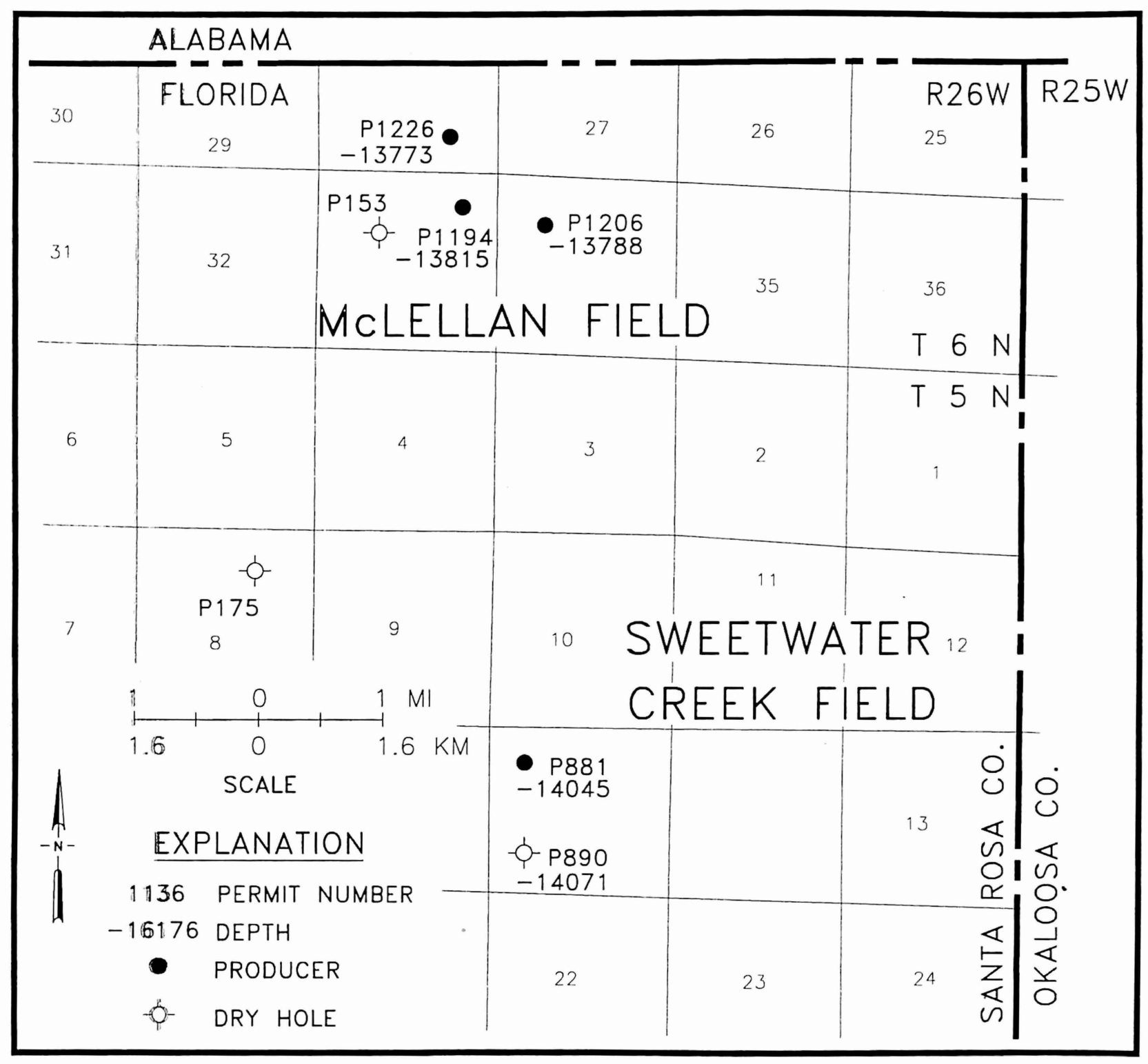

Figure 19. McLellan and Sweetwater Creek fields well location map. 
20). Core analysis of a potential oil and gas productive zone from $-13,819$ to $-13,845$ feet MSL by Core Laboratories, Inc. (Dallas, Texas) indicated a mean porosity of 12.3 percent. The analysis showed additional oil and gas production potential between $-13,854$ and $-13,863$ feet MSL. Mean porosity is about 15 percent for this zone. Both of the analyzed zones contained dark, fine grained, microcrystalline dolostones with vuggy porosity.

McLellan field is located within the area known to be underlain by the Louann Salt and may have a saltrelated trap structure. It is also located within a few miles of the approximate updip limits of the Smackover Formation (Lloyd, 1989; Applegate et al., 1978; Ottman et al., 1973, 1976); thus, the trap could be a stratigraphic pinchout. Current data does not reveal which trap mechanism produced the Smackover reservoir for this field.

The first offset and confirmation well for the field was the Exxon Corporation - State of Florida number 34-2 (permit 1206). It is located about one-half mile east of the discovery well (Figure 19). It was tested on March 9, 1987 and flowed 641 barrels of $43.4^{\circ}$ A.P.I. gravity oil and 24 barrels of saltwater per day. The Smackover Formation was encountered at $-13,788$ feet MSL, 27 feet higher than in the discovery well (Figure 20). Production is from the Smackover Formation from $-13,797$ to $-13,847$ feet MSL. Core analysis by All Points, Inc. (Houston,
Texas) yielded a mean porosity of 11.5 percent for the productive zone.

A second offset to the discovery well, Exxon Corporation - State of Florida number 28-4 (permit 1226) was drilled about one-half mile north of the discovery well (Figure 19). During initial production tests, in February 1988, the well flowed 154 barrels of oil (gravity not reported) and 171 barrels of saltwater per day. The Smackover was encountered 42 feet higher in this well than in the discovery well (Figure 20), indicating a fairly steep gradient between these wells. This second offset well has since been converted to a salt water disposal well. As of December 1995, production for McLellan field was from the two remaining wells and totaled 351,617 barrels of oil (Appendix 2 and $3)$.

\section{SWEETWATER CREEK FIELD}

Sweetwater Creek field was discovered on April 22, 1977, with the successful flow test of the Houston Oil and Minerals Corporation - W. M. Stokes number 15-2 well (permit 881, Appendix 1, Figures 3 and 19). The well is located in Section 15, Township 5 North, Range 26 West, Santa Rosa County. In the initial test the well produced 624 barrels of $43.5^{\circ}$ A.P.I. gravity oil and only a trace of saltwater from a Smackover limestone interval from $-14,044$ to $-14,085$ feet MSL. This test data spurred rumors that a "new Jay" field had been discovered. Rumors proved to be false and an 


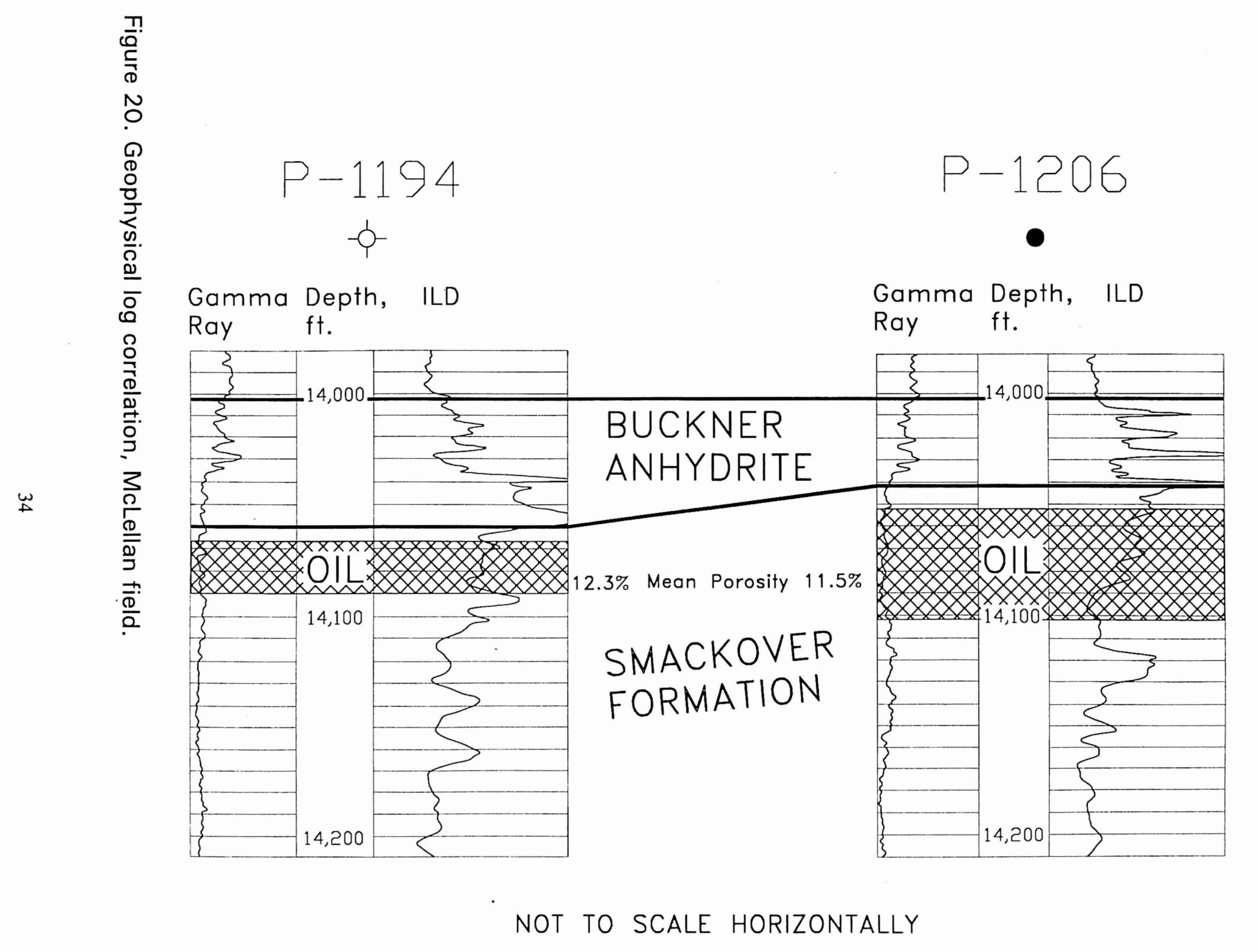

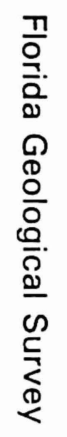


offset drilled in 1978 to the south of the discovery well was dry (permit 890 , Figure 19). Core analyses of the Smackover Formation in the offset well by Core Laboratories, Inc. (Dallas, Texas) indicated very fine crystalline, gray brown limestone and dolostone, with low porosity and permeability, and potential for only saltwater production. The field produced a total of 13,695 barrels of oil during its entire lifetime (Appendix 2). The discovery well was the only producer at Sweetwater Creek field and was plugged and abandoned in December 1980, after it began producing 100 percent saltwater.

\section{South Florida Oil Field Summaries}

\section{INTRODUCTION}

South Florida oil production began with Florida's first oil discovery at Sunniland field in September, 1943. There are now 14 oil fields in south Florida, oriented in a northwestsoutheast trend through Lee, Hendry, Collier and Dade Counties (Figure 1). Of these 14 Sunniland trend oil fields, seven are active, three are temporarily shut-in, and four are plugged and abandoned.

Reservoirs found along the Sunniland trend are composed of localized buildups of organic debris into mounds or pods which formed porous grainstones within the upper Sunniland Formation (Figure 2). The fauna which make up these bioherms include rudistids, algal plates, gastropods, and foraminifera. Dolomitization has enhanced the porosity of these grainstones. The grainstones grade laterally into nonporous, miliolid-rich mudstones (Means, 1977; MitchellTapping, 1984, 1985, and 1986). These miliolid mudstones often provide the trapping mechanism for these reservoirs.

The exception to the above general description of south Florida oil fields is Lake Trafford field. Lake Trafford produces oil from a fractured limestone in the lower Sunniland Formation (Means, 1977).

\section{LEHIGH PARK FIELD}

The discovery well for the Lehigh Park field was the Exxon Consolidated - Tomoka number 22-4 (permit 712) drilled in Section 22, Township 44 South, Range 26 East, Lee County (Appendix 1, Figures 1 and 21). This is the most northwesterly field in the Sunniland trend. The discovery well was completed on July 30,1974 , in the $-11,349$ to $-11,354$ foot MSL interval of the Sunniland Formation. Initial production was 490 barrels of $27.6^{\circ}$ A.P.I. gravity oil and 48 barrels of saltwater per day. This well was later abandoned and a deviated well (permit 712A) was drilled at the same surface location to produce higher on the structure. A total of nine dry holes were drilled to delineate this field. All of the producing wells were directionally drilled because bottom hole locations are beneath the town of Lehigh Acres. 


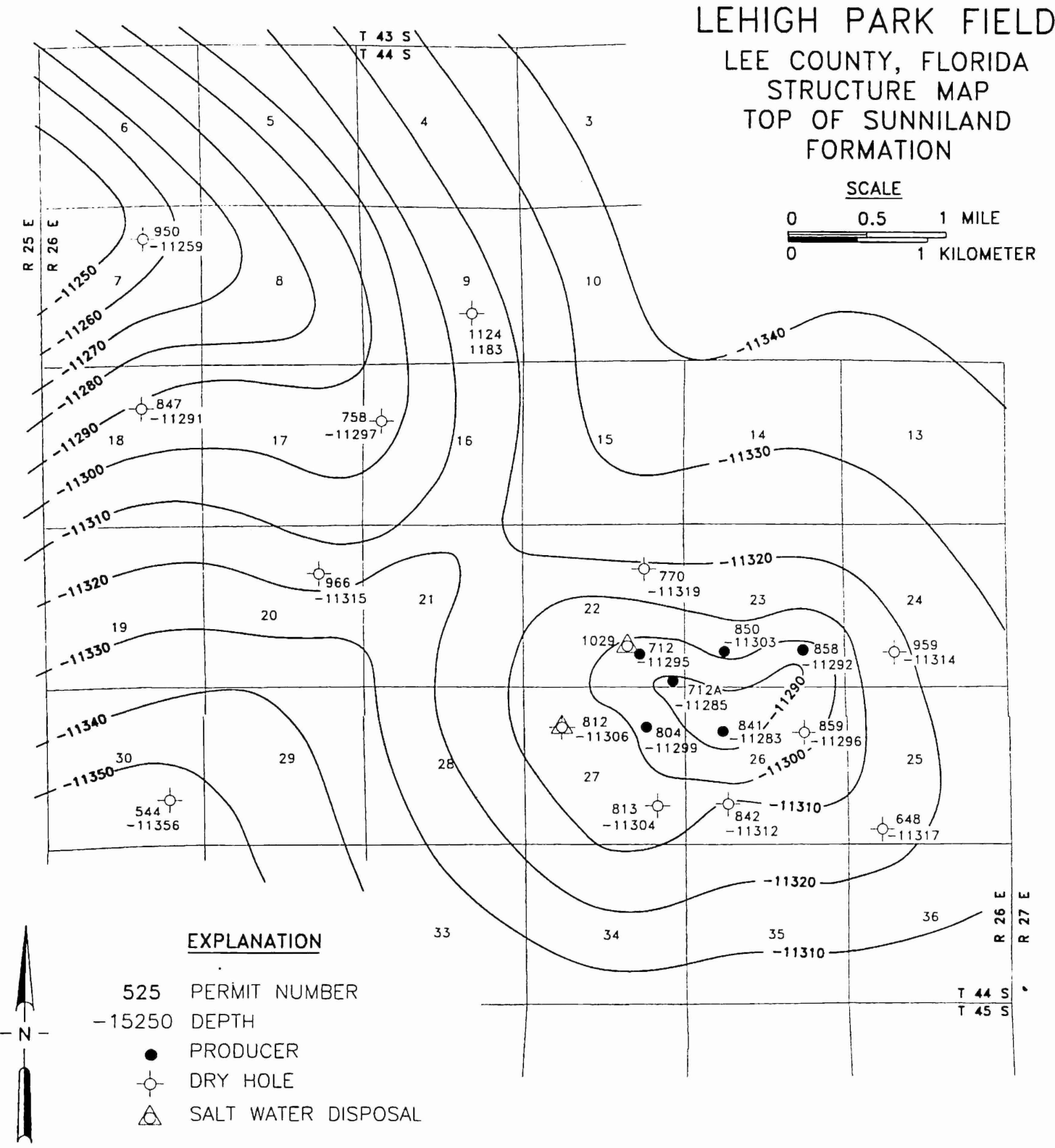

Figure 21. Lehigh Park field structure map, top of Sunniland Formation (after Ferber, 1985) 
Figure 21 is a structure map of the top of the Sunniland Formation (Ferber, 1985) at Lehigh Park field. The reservoir appears to be typical of the south Florida Sunniland trend fields, a leached limestone bioherm. Core analysis by R. E. Laboratories, Inc. (Dallas, Texas) yielded an average porosity of 19.7 percent for the Sunniland Formation from $-11,337$ to $-11,364$ feet MSL. They described this interval as a tan to brown, fossiliferous, partially dolomitized limestone.

One well was actively producing, and production totaled $5,462,076$ barrels of oil at the end of December 1995 for this field (Appendices 2 and 3).

\section{TOWNSEND CANAL FIELD}

Townsend Canal field is located in Section 2, Township 45 South, Range 28 East, Hendry County, approximately three miles north of MidFelda field, within the Sunniland trend (Figure 1). It was discovered on June 27, 1982, with the first production test of the Natural Resources Management Corporation - A. Duda \& Sons number 2-3 well (permit 1070). The test produced 160 barrels of $28.4^{\circ}$ A.P.I. gravity oil and 42 barrels of saltwater per day. Production is from the Sunniland Formation between $-11,363$ and $-11,368$ feet MSL (Appendix 1).

One well was producing at Townsend Canal field at the end of 1995 (Appendix 3). Production totaled
526,420 barrels of oil at the end of 1995 (Appendix 2).

\section{WEST FELDA FIELD}

West Felda field was discovered on August 2, 1966, with the drilling of the Sun - Red Cattle number 21-3 well (permit 371) in Section 21, Township 45 South, Range 28 East, Hendry County. The filed now extends into Lee County (Appendix 1, Figures 1 and 22). The first production test yielded 56 barrels of $24.6^{\circ}$ A.P.I. gravity oil and 148 barrels of saltwater per day from the $-11,437$ to $-11,440$ foot $\mathrm{MSL}$ interval of the Sunniland Formation.

The field is mainly a stratigraphic trap; however, structural closure is more evident than at Sunoco Felda field (Figure 22). The main producing unit has a composition typical of the south Florida Sunniland trend fields (Means, 1977; Mitchell-Tapping, 1986). Means (1977) summarized the reservoir characteristics for West Felda field as follows: average pay thickness of 17 feet, average porosity of 20 percent, average water saturation of 35 percent, A.P.I. oil gravity of $26^{\circ}$, and average daily oil production of 4,600 barrels. Values indicate improved reservoir quality over Sunoco Felda field.

Means (1977) believed that the reservoir quality was improved because West Felda field "experienced higher energy and more-normal marine conditions" than did Sunoco Felda field. Alternatively, Mitchell-Tapping (1986) considered the energy levels 


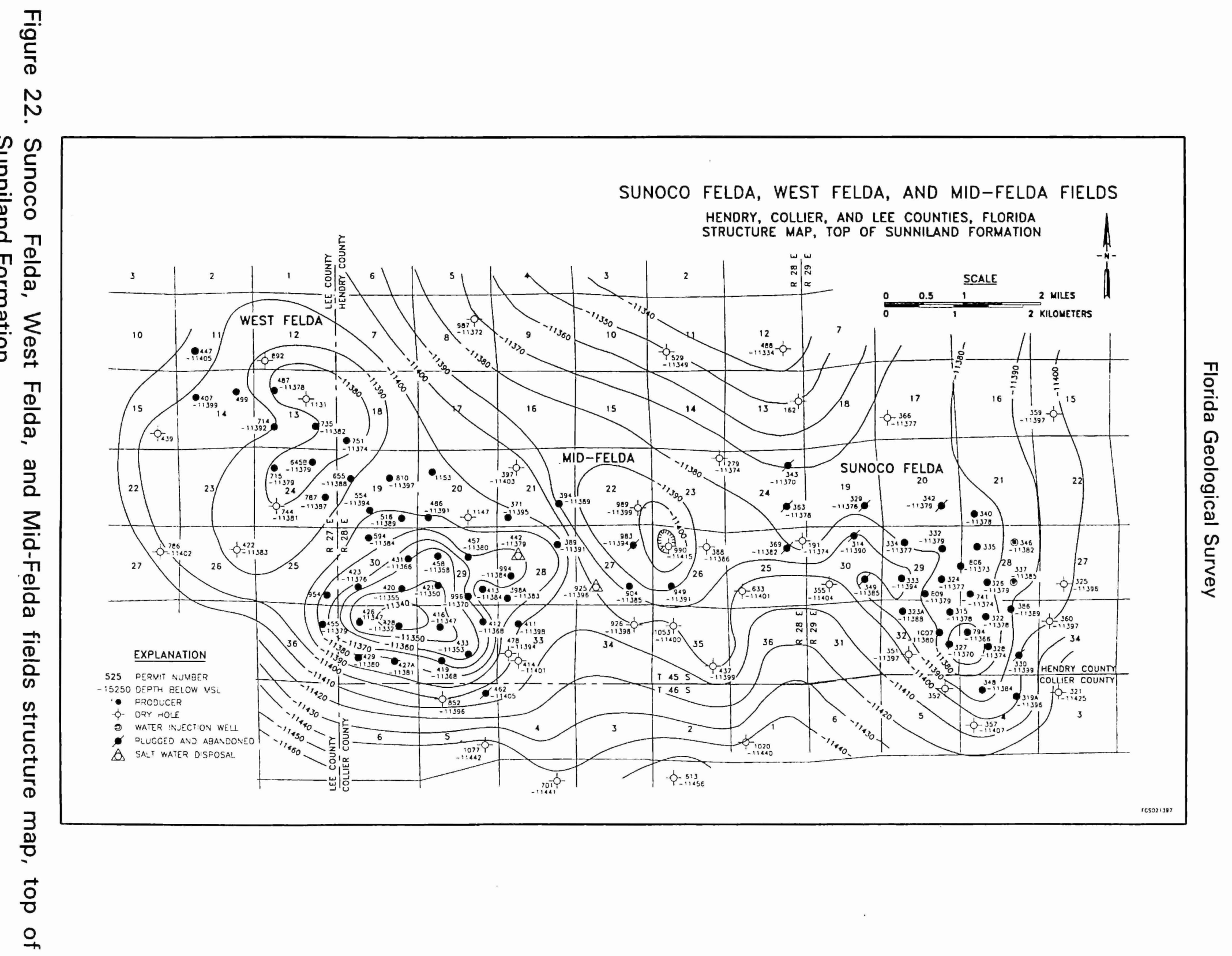


topographically higher" at West Felda field.

At the end of December 1995, six wells were producing at West Felda field and cumulative production totaled $43,301,266$ barrels of oil (Appendices 2 and 3 ).

\section{MID-FELDA FIELD}

The Mid-Felda field discovery well was the R. L. Burns - Red Cattle number 27-4 (permit 904) in Section 27, Township 45 South, Range 28 East in Hendry County, Florida (Appendix 1). The well was completed in the $-11,433$ to $-11,437$ foot MSL interval of the Sunniland Formation on October 13, 1977. An initial production test on October 24, 1977 yielded 281 barrels of $26^{\circ}$ A.P.I. gravity oil and 53.6 barrels of saltwater per day (Appendix 1).

The well is located on a small subsurface feature between West Felda field and Sunoco Felda field (Figure 22). Samples from the producing zone show a partially dolomitized fossil hash with about ten feet of oil staining. Geophysical log analysis indicated approximately 20 percent porosity for an eight-foot interval (Applegate and Lloyd, 1985).

At the end of 1995, two wells were actively producing (Appendix 3 ). Cumulative production, as of the end of December 1995 was 1,484,994 barrels of oil (Appendix 2).

\section{SUNOCO FELDA FIELD}

The Sunoco Felda-field, located in Hendry and Collier Counties, was discovered in July 1964 by Sunoco, when they drilled the discovery well (Appendix 1). The well (the Sun - Red Cattle number $32-1$; permit 315$)$ is located in Section 32, Township 45 South, Range 29 East. Sunoco Felda was the second commercial oil field discovered in Florida and was discovered 21 years after the first commercial discovery (Sunniland field). Forty Mile Bend field was discovered in 1954 but turned out to be noncommercial and was abandoned in 1956. The Sunoco Felda discovery well location was based on a combination of subsurface and seismic data (Tyler and Erwin, 1976).

In an initial pumping test in November 1964, the discovery well produced 427 barrels of $25.4^{\circ}$ A.P.I. gravity oil and 11 barrels of saltwater per day. Production is from the Sunniland Formation from $-11,417$ to $-11,430$ feet MSL from a leached limestone bioherm. The faunal composition of the bioherm is somewhat typical of the Sunniland reservoirs (as described in the south Florida oil fields introduction above) (Means, 1977; Mitchell-Tapping, 1986). Mitchell-Tapping (1986) observed faunal differences at Sunoco Felda field which indicated formation in "the shallow lagoonal zone of the backreef environment." The reservoir has a permeability barrier to the northeast 
"the shallow lagoonal zone of the backreef environment." The reservoir has a permeability barrier to the northeast which prevents migration of the oil updip (Tyler and Erwin, 1977).

Means (1977) summarized the reservoir characteristics of Sunoco Felda field. These include an average pay zone thickness of 11 feet, average porosity of 18 percent, average water saturation of 50 percent, A.P.I. oil gravity of $25^{\circ}$, and average daily oil production of 1,700 barrels.

The last reported production from Sunoco Felda field was in August, 1992 and all producing wells have been plugged and abandoned. The total production for this field was $11,528,000$ barrels of oil (Appendix 2).

\section{CORKSCREW FIELD}

Corkscrew field was discovered on November 10, 1985 with an initial swab test of the R. K. Petroleum - Rex Properties number 33-2 (permit 1170, Appendix 1). Corkscrew field is located about two and one-half miles north and slightly west of the one-well Lake Trafford field in Collier County, Florida (Figures 1 and 23). In its initial test, the discovery well produced 435 barrels of $25^{\circ}$ A.P.I. gravity oil per day with no saltwater. Production was from open hole in the Sunniland at $-11,502$ to $-11,520$ feet MSL.

Core analysis by Analytical Logging, Inc. (Ft. Myers, Florida) indicated an oil producing zone from $-11,506$ to $-11,515$ feet MSL. The zone was described as a "fossil-hash" of dolomitic limestone with an average porosity of 15.25 percent. This description, and the small closed structure drawn by LeBar (Petroleum, Engineer, Florida Geological Survey, personal communication, 1996) (Figure 23), are again consistent with a bioherm formation for the reservoir.

Two successful offsets have been drilled at Corkscrew field (Figure 23, permits 1199 and 1201A) (Lloyd, 1989). In addition, permit 1243C, a reentry and sidetrack of the Permit 1224 (a dry hole), was completed as a producer in 1993, but was ultimately deemed non-commercial. Corkscrew field's total oil production as of January 1, 1996 was 966,703 barrels (Appendix 2).

\section{LAKE TRAFFORD FIELD}

Lake Trafford field was discovered by Mobil Oil Corporation on the Baron Collier Jr. lease in Section 9, Township 47 South, Range 28 East in Collier County (Figures 1 and 24). The discovery well (permit 401) was completed on March 30, 1969 (Appendix 1). During initial production tests the well pumped 118 barrels of $25.6^{\circ}$ A.P.I. gravity oil and 78 barrels of saltwater per day. Production was from the Sunniland Formation from $-11,830$ to $-11,892$ feet MSL. The well was later squeeze cemented to shut off water from above the perforations. The well is unique in south Florida in that it has not produced water since that time. 


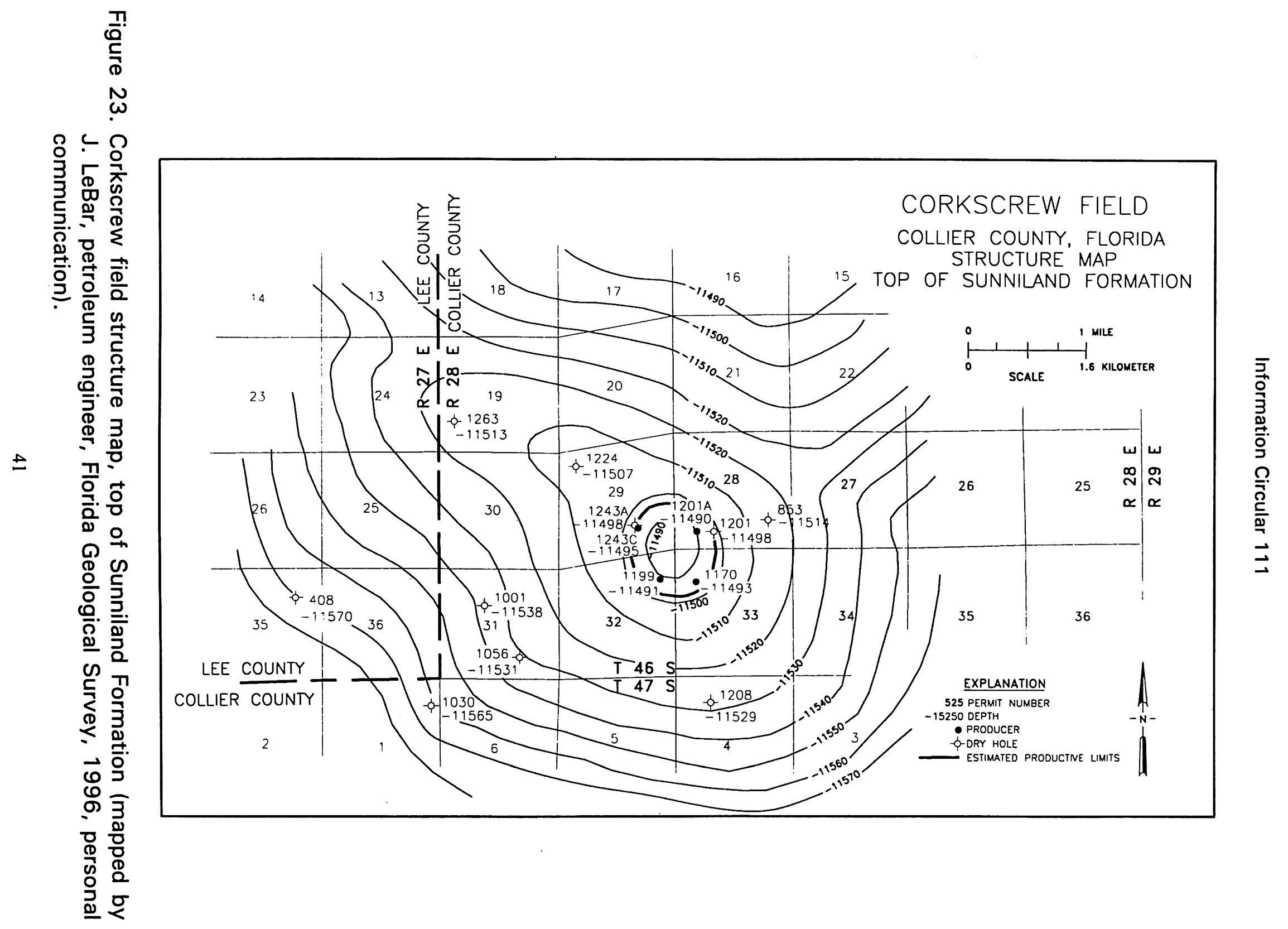


Florida Geological Survey

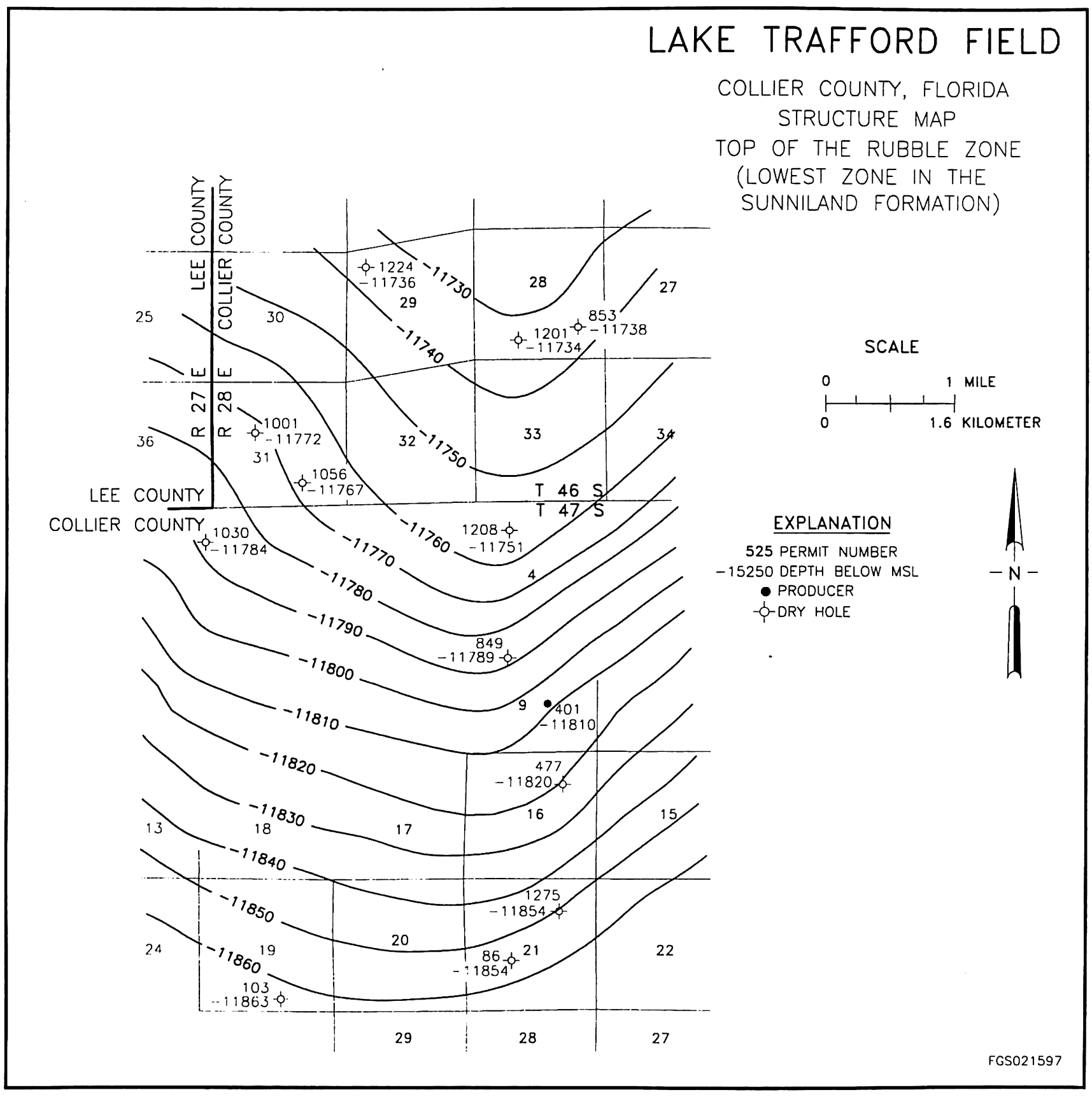

Figure 24. Lake Trafford field structure map, top of rubble zone, Sunniland Formation (lowest zone in Sunniland Formation, mapped by J. LeBar, petroleum engineer, Florida Geological Survey, 1996, personal communication). 
Lake Trafford field is also unique in south Florida as the only field which produces oil from a fractured limestone in the lower Sunniland Formation (Means, 1977). This producing horizon has been described as an argillaceous, burrowed, limestone "rubble." Figure 24 is a structure map on top of this "Rubble Zone" as mapped by Jim LeBar (Petroleum Engineer, Florida Geological Survey, personal communication, 1996). The combination of burrowing and fracturing was believed to be responsible for the development of producible permeability and porosity (Jim Richter, Mobil Oil Corporation, personal communication, in Applegate and Lloyd, 1985).

Offsets drilled northwest and south of the discovery well were dry holes. The discovery well remains the single producing well for Lake Trafford field. The well has been periodically shut-in due to mechanical problems and has been producing only sporadically since March 1988 . This well is still capable of producing substantial reserves if the mechanical problems can be solved (Jim LeBar, Petroleum Engineer, Florida Geological Survey, personal communication, 1996). The last reported production was during 1992. Total oil production for this field, as of January 1996, was 278,000 barrels (Appendix 2).

\section{SUNNILAND FIELD}

In September 1943, Humble Oil and Refining Company discovered
Sunniland field in Collier County, Florida (Appendix 1, Figures 1 and 25). This was the first commercial oil discovered in Florida. The discovery well was the Humble Oil and Refining Company - Gulf Coast Realties number 1 (permit 42) located in Section 29, Township 48 South, Range 30 East. The well was completed in an open hole interval between $-11,568$ and $-11,592$ feet MSL. Initial production was 97 barrels of $26^{\circ}$ A.P.I. gravity oil and 425 barrels of saltwater per day by pumping.

The well was drilled on a prospect outlined by magnetic, gravity, seismic, and core data. Production in the field is from various porous zones in rudistid mounds in the upper 60 feet of the formation. Mitchell-Tapping (1985) described the producing horizon as consisting of leached rudist and algal particles together with pellets and foraminifers. Mitchell-Tapping's (1985) study of Sunniland, Bear Island, and Forty Mile Bend fields concluded that the depositional environment of these fields was that of a tidal shoal with a landward (east-northeast) mud-flat area and a seaward (west-southwest) shallow-water back-reef area. The structure map (Figure 25) for the Sunniland field shows a northwestsoutheast trending dome that formed as these rudistid beds grew with slowly-rising sea level during the Lower Cretaceous. The dome is about four miles long and two miles wide with closure of about 40 feet.

Twenty-six producing wells and ten dry holes have been drilled at 
Florida Geological Survey

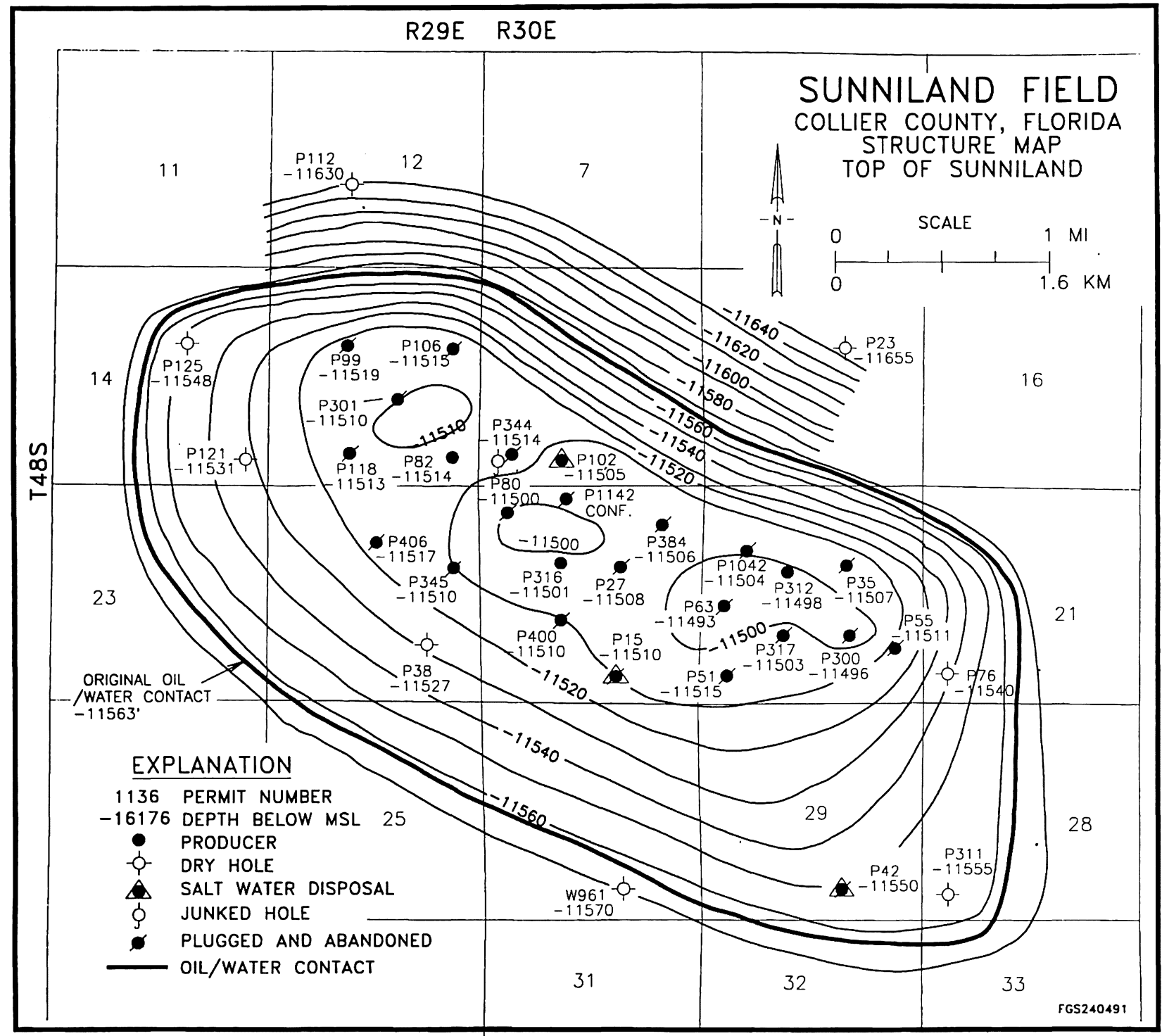

Figure 25. Sunniland field structure map, top of Sunniland Formation. 
Sunniland field. After producing oil for over 50 years, increased saltwater production has forced abandonment of Sunniland field. All but two of the producing wells have been plugged and abandoned. It is unlikely that the remaining two wells (which are shut-in) will produce any additional oil (Jim LeBar, Petroleum Engineer, Florida Geological Survey, personal communication, 1996). The oil production total for Sunniland field, as of January 1996, was 18,445,000 barrels of oil (Appendix 2).

\section{SEMINOLE FIELD}

The discovery well for the Seminole field was the Weiner-Oleum Corporation well number 12-1 (permit 662) in Section 12, Township 48 South, Range 32 East, Hendry County (Appendix 1, Figure 1). The well was completed in the $-11,379$ to $-11,384$ foot MSL interval of the Sunniland Formation on November 14, 1973. Initial production was 26 barrels of $25.4^{\circ}$ A.P.I. gravity oil and eight barrels of saltwater per day. This three-well oil field was abandoned in 1978 after producing a total of 85,000 barrels of oil (Appendix 2).

\section{BEAR ISLAND FIELD}

Bear Island field was discovered on December 5, 1972, with the completion of the Exxon - Gulf Coast Realties number 2-4 well (permit 563) in Section 2, Township 49 South,
Range 30 East (Appendix 1, Figures 1 and 26). The field is located about two miles southeast of Sunniland field. The discovery well pumped 132 barrels of $26^{\circ}$ A.P.I. gravity oil and 545 barrels of saltwater per day from perforations between $-11,558$ and $-11,564$ feet MSL in Sunniland carbonates.

The structure map of Bear Island field (Figure 26) indicates a northwestsoutheast trending dome about 4.5 miles long and 2.5 miles wide with a closure of about 55 feet. MitchellTapping (1985) found this field to have the same faunal assemblage as Sunniland field; his conclusion concerning the general depositional environment is listed above in the description of Sunniland field. Despite the generally similar origin, MitchellTapping (1985) found Bear Island field to be lithologically different from Sunniland field. Most of the Sunniland Formation at Bear Island field is dolomitized and is more leached than at Sunniland field. Anhydrite and some secondary dolomitization has reduced the effective permeability in some sections. Dolomitization in the lower units of the upper Sunniland, however, enhanced both porosity and permeability (Mitchell-Tapping, 1985).

A total of 25 producing wells have been drilled at Bear Island field; five of these were active at the end of 1995 (Appendix 3). Total oil production, through December 1995, was 11,318,991 barrels (Appendix 2). 
Florida Geological Survey

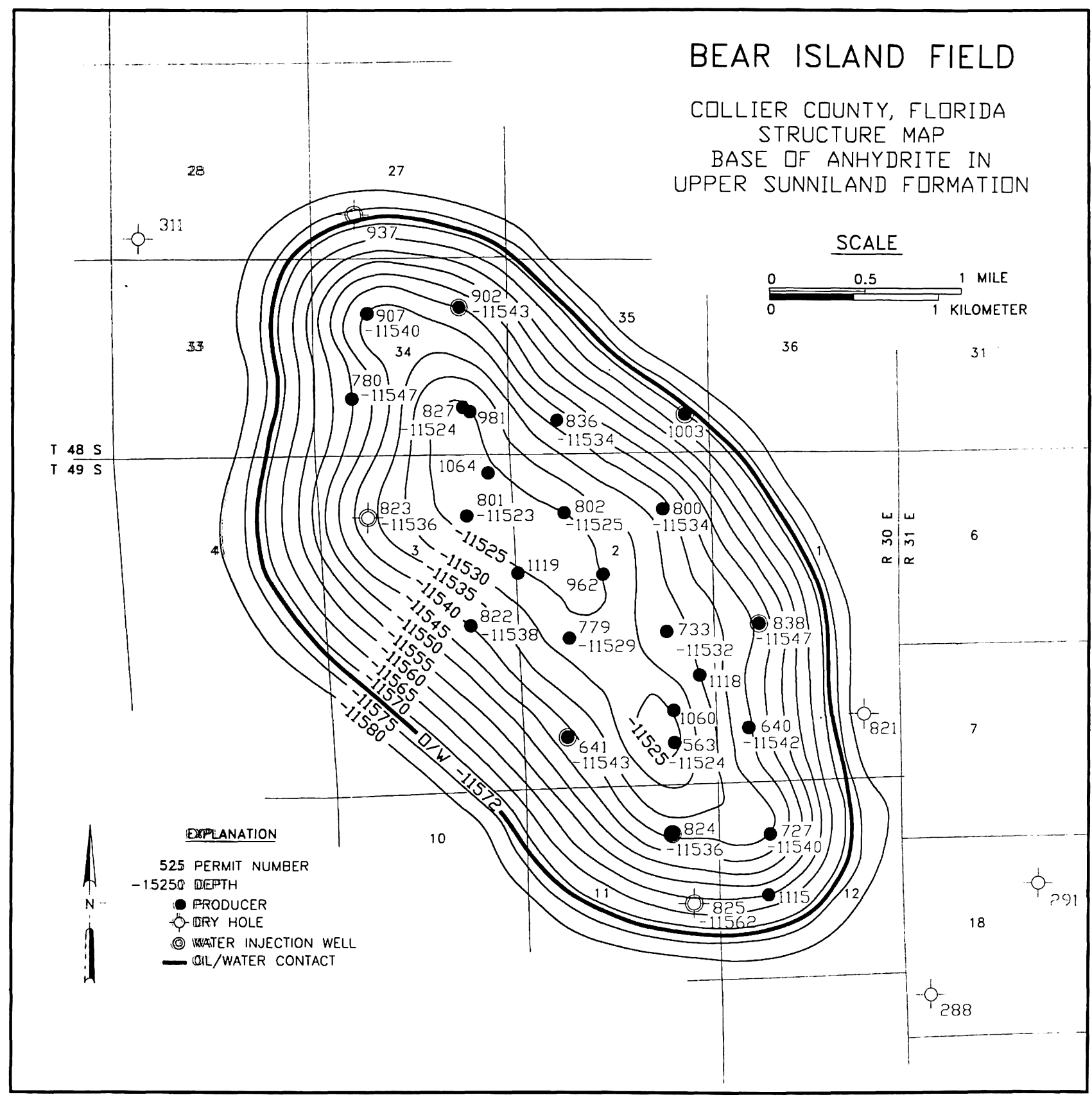

Figure 26. Bear Island field structure map, base of anhydrite in Upper Sunniland Formation (after Bear Island Geological Committee, 1978). 
Information Circular 111

\section{PEPPER HAMMOCK FIELD}

Pepper Hammock was discovered on September 28, 1978. The discovery well, the Exxon Corporation - Collier Company number 23-1 well (permit 897), is located in Section 23, Township 29 South, Range 30 East, approximately one and one-half miles south of Bear Island field (Appendix 1, Figure 1). The initial production test yielded 20 barrels of $27^{\circ}$ A.P.I. gravity oil and 206 barrels of saltwater per day. Production was from Sunniland limestones between -11,586 and $-11,590$ feet MSL. The discovery well is the only well at Pepper Hammock and is shut-in. A total of 323 barrels of oil were produced before the well was shut-in in October 1978 (Appendix 2).

\section{BAXTER ISLAND FIELD}

Baxter Island field is a one-well, abandoned field located approximately eight miles southeast of Bear Island field (Figure 1). The single producer and discovery well was the Diamond Shamrock - Gerry Brothers Ltd. number 31-3 well (permit 865) located in Section 31, Township 49 South, Range 32 East, Collier County (Appendix 1). In its initial production test on August 11, 1977, the well pumped 35 barrels of $22.4^{\circ}$ A.P.I. gravity oil and 220 barrels of saltwater per day. Production was from the Sunniland Formation from $-11,482$ to $-11,485$ feet MSL. The field produced a total of 1,859 barrels of oil before the well was shut-in in 1978 (Appendix $2)$. The well was plugged and abandoned on January 12, 1980.

\section{RACCOON POINT FIELD}

Raccoon Point field is the southeastern-most active field in the Sunniland trend (Figure 1). Its discovery well was the Exxon -Oleum Corporation number 33-4 (permit 829) drilled in Section 33, Township 51 South, Range 43 East, Collier County (Appendix 1, Figure 27). Initial production was from the $-11,371$ to $-11,375$ foot MSL interval of the Sunniland Formation. In a production test on June 20, 1978, the well pumped 57 barrels of $23.3^{\circ}$ A.P.I. gravity oil and 845 barrels of saltwater per day.

Figure 27 indicates a structure similar to other Sunniland producing fields. At the end of 1995, six wells were actively producing (Appendix 3 ). Oil production totaled 8,569,027 barrels at the end of December 1995 (Appendix 2).

\section{FORTY MILE BEND FIELD}

Commonwealth Oil Company drilled the Wiseheart - State Board of Education number 1 wildcat (permit 167) in Section 16, Township 45 South, Range 35 East, Dade County. It was located 50 miles southeast of Sunniland field (Appendix 1, Figure 1). The well was completed in the $-11,298$ to $-11,315$ foot MSL interval of the Sunniland Formation and was initially 
Florida Geological Survey

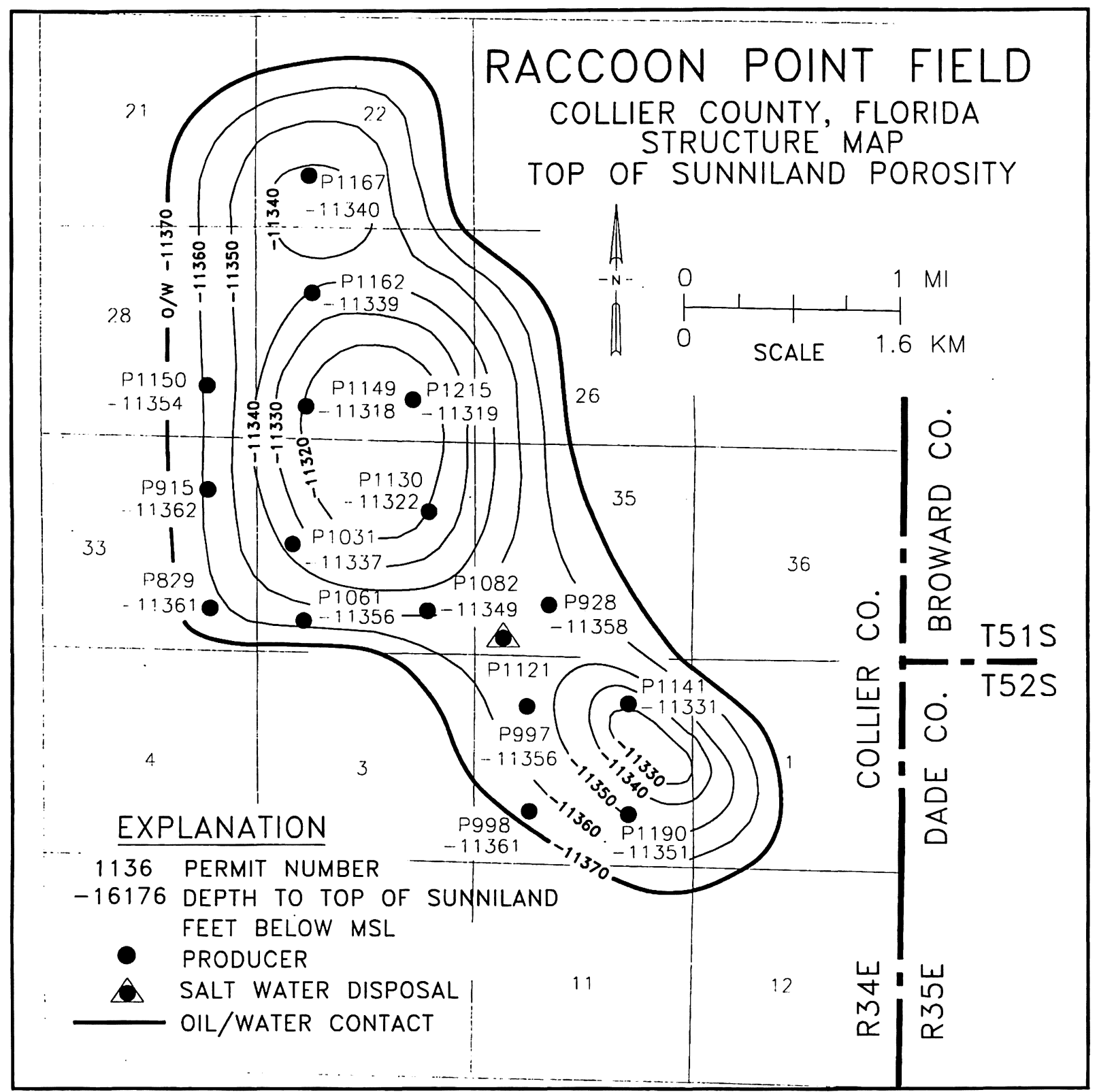

Figure 27. Raccoon Point field structure map, top of Sunniland Formation porosity (after Raccoon Point Geological Committee, 1993). 
tested on February 5, 1954. In this initial test, the well pumped an estimated 76 barrels of $21.3^{\circ}$ A.P.I. gravity oil and 96 barrels of saltwater per day. Core examination (Applegate and Lloyd, 1985) in the open interval showed a partially to fully oil-saturated, finely crystalline dolostone and limestone with pin-point porosity, which did not appear to be commercial.

The second well in the Forty Mile Bend field, the Gulf Oil - State of Florida number 1 well (permit 182), was also completed in 1954 . The well is located about three and one-quarter miles east of the discovery well (Figure 1). It was completed as a pumping well in the $-11,309$ to $-11,316$ foot MSL interval of the Sunniland Formation. Initial production was 112 barrels of $21.7^{\circ}$ A.P.I. gravity oil per day. Water production was not tabulated.

The distance between the two wells comprising Forty Mile Bend field indicate that they probably did not produce from the same reservoir.
Mitchell-Tapping (1985) studied the fauna and lithology of Sunniland, Bear Island, and Forty Mile Bend fields. His description of the depositional environment for these fields is discussed above in the Sunniland field description. He found the lithology and fauna at Forty Mile Bend to be similar to that of Sunniland field, except for the presence of anhydrite in the pore space and an increase in the dolomite content.

Low oil gravity and low porosity and permeability in the Sunniland at both well locations made this field noncommercial. In addition, a half-inch hole was found in the casing of the Gulf well (permit 182) at $-10,027$ feet MSL. This could have caused excessive water flow, and thus shortened the productive life of this well. Both of the Forty Mile Bend wells were abandoned in 1956, after producing only 32,888 barrels of oil in about 17 months in 1954 and 1955 (Appendix 2) (Gunter, 1955 and 1956). 


\section{REFERENCES}

Applegate, A. V. and Lloyd, J. M., 1985, Summary of Florida petroleum production and exploration, onshore and offshore, through 1984: Florida Geological Survey Information Circular no. 101, 69 p.

, Pontigo, F. A., Jr., and Rooke, J. H., 1978, Jurassic Smackover oil prospects in the Apalachicola embayment: Oil and Gas Journal, January 23, 1978 , v. 76 , no. 4 , p. $80-84$.

, Winston, G. O., and Palacas, J. G., 1981, Subdivision and regional stratigraphy of the Pre-Punta Gorda Rocks (lowermost Cretaceous-Jurassic?) in south Florida: Supplement to Transactions of the Gulf Coast Gulf Coast Association of Geological Societies, v. 31, p. 447-453.

Bear Island Geological Committee, 1978, Bear Island field structure map, Exxon Corporation Sunniland oil pool report: Florida Department of Natural Resources Hearing no. 40.

Blackjack Creek Geological Committee, 1974, Blackjack Creek field unit, Exhibit M-1: Florida Department of Natural Resources Hearing no. 38.

Bradford, C. A., 1984, Transgressive-regressive carbonate of the Smackover Formation, Escambia County, Alabama: in Ventress, W. P. S., Bebout, D. G., Perkins, B. F., and Moore, C. H. (editors), The Jurassic of the Gulf Rim: Proceedings of the third annual research conference, Gulf Coast Section, Society of Economic Paleontologists and Mineralogists Foundation, p. 27-39.

Christian, L. D., Shirer, J. A., Kimbel, E. L., and Blackwell, R. J., 1981, Planning a tertiary oil-recovery project for Jay/LEC fields unit: Journal of Petroleum Technology, v. 33, p. 1535-1544.

Ferber, R., 1985, Depositional and diagenetic history of the Sunniland Formation, Lower Cretaceous, Lehigh Park field, Lee County, Florida: Master's thesis, University of Southwestern Louisiana, Lafayette, Louisiana.

Gould, G. J., 1989, Gulf of Mexico Update: May 1988 - July 1989, U. S. Department of the Interior Minerals Management Service: OCS Information Report, MMS 89-0079, $51 \mathrm{p}$. 
Information Circular 111

Gunter, H., 1955, Exploration for oil and gas in Florida, Florida Geological Survey, 1954 Supplement to Information Circular no. 1, 35 p.

, 1956, Exploration for oil and gas in Florida, Florida Geological Survey, 1955 Supplement to Information Circular no. 1, 31 p.

Hughes Eastern Corporation, 1988, McDavid Prospect, Escambia County, Florida, Top Smackover, Geophysical Map: Florida Department of Natural Resources Hearing no. 42.

Jay-LEC Fields Unit Geological Committee, 1974, Structure map-top of SmackoverNorphlet oil pool, Exhibit no. G-1: Florida Department of Natural Resources Hearing no. 36.

Johnson, P. G. and Tucker, D. L., 1987, The federal Outer Continental Shelf oil and gas leasing program: a Florida perspective, February, 1987: Office of the Governor, Office of Planning and Budgeting, Intergovernmental Unit, 16 p.

Karpas, R. M., and Gould, G. J., 1990, Atlantic update: July 1986 - June 1990, Outer Continental Shelf oil and gas activities, U. S. Department of the Interior Minerals Management Service: OCS Information Report, MMS 90-0060, 57 p.

Langston, E. P., and Shirer, J. A., 1985, Performance of the Jay-LEC field unit under mature waterflood and early tertiary operations: Journal of Petroleum Technology, v. 37, p. 261-268.

, Shirer, J. A., and Nelson, D. E., 1981, Innovative reservoir management - key to highly successful Jay-LEC waterflood: Journal of Petroleum Technology, v. 33, p. 783-791.

Lloyd, J. M., 1994, 1992 and 1993 Florida petroleum production and exploration: Florida Geological Survey Information Circular no. 110, 30 p.

, 1992, 1990 and 1991 Florida petroleum production and exploration: Florida Geological Survey Information Circular no. 108, 31 p.

1991, 1988 and 1989 Florida petroleum production and exploration: Florida Geological Survey Information Circular no. 107, Part I, p. $1-62$. 
, 1989, 1986 and 1987 Florida petroleum production and exploration: Florida Geological Survey Information Circular no. 106, 39 p.

, 1986, Bluff Springs field discovery renews interest in Florida's western panhandle: Oil and Gas Journal, June 30,1986 , v. 84 , no 3, p. 105108.

, and Applegate, A. V., 1987, 1985 Florida petroleum production and exploration: Florida Geological Survey Information Circular no. 104, Part I, p. $1-42$.

, and Ragland, J. M., 1991, Petroleum exploration and development policies in Florida: Response to public concern for sensitive environments: Florida Geological Survey Information Circular no. 107, Part II, p. 63-82.

, Ragland, P. C., Ragland, J. M., and Parker, W. C., 1986, Diagenesis of the Jurassic Smackover Formation, Jay field, Florida: Gulf Coast Association of Geological Societies Transactions, v. 36, p. 201-211.

Lomando, A. J., Jr., Schreiber, C., and Nurmi, R. D., 1981, Sedimentation and diagenesis of Upper Smackover grainstone, Jay-field area, west Florida (abstract): American Association of Petroleum Geologists Bulletin, v. 65, no. 5, p. 950.

Mancini, E. A., and Benson, D. J., 1980, Regional stratigraphy of Upper Jurassic Smackover carbonates of southwest Alabama: Gulf Coast Association of Geological Societies Transactions, v. 30, p. 151-165.

Means, J. A., 1977, Southern Florida needs another look: The Oil and Gas Journal, v. 75 , no. 5 , p. $212-225$.

Miller, J., 1974, Mount Carmel field structure map: Florida Department of Natural Resources Hearing no. 27.

Mitchell-Tapping, H., 1984, Petrology and depositional environment of the Sunniland producing fields of south Florida: Gulf Coast Association of Geological Societies Transactions, v. 34, p. 157-173.

, 1985, Petrology of the Sunniland, Forty Mile Bend and Bear Island fields of south Florida: Gulf Coast Association of Geological Societies Transactions, v. 35, p. 233-242. 
Information Circular 111

, 1986, Exploration petrology of the Sunoco Felda trend of south Florida: Gulf Coast Association of Geological Societies Transactions, v. 36, p. 241-256.

Moore, C. H., 1984, The Upper Smackover of the Gulf Rim: depositional systems, diagenesis, porosity evolution and hydrocarbon development: in Ventress, W. P. S., Bebout, D. G., Perkins, B. F., and Moore, C. H. (editors), The Jurassic of the Gulf Rim: Proceedings of the third annual research conference, Gulf Coast Section, Society of Economic Paleontologists and Mineralogists Foundation, p. 283-307.

Ottman, R. D., Keyes, P. L., and Ziegler, M. A., 1973, Jay field - a Jurassic stratigraphic trap: Gulf Coast Association of Geological Societies Transactions, v. 23, p. 146-157.

, 1976, Jay field - a Jurassic stratigraphic trap: in Braunstein, J. (editor), North American oil and gas fields: American Association of Petroleum Geologists Memoir 24, p. 276-286.

Raccoon Point Geological Committee, 1993, Structure Map - Top of Sunniland Porosity, Florida Department of Environmental Protection Order No. 93-1-45: Unitization of Raccoon Point Field.

Shirer, J. A., Langston, E. P., and Strong, R. B., 1978, Application of field-wide conventional coring in the Jay-Little Escambia Creek Unit: Journal of Petroleum Technology, v. 30, p. 1774-1780.

Sigsby, R. J., 1976, Paleoenvironmental analysis of the Big Escambia Creek-JayBlackjack Creek field area: Gulf Coast Association of Geological Societies Transactions, v. 26, p. 258-278.

Tyler, A. N. and Erwin, W. L., 1976, Sunoco-Felda field, Hendry and Collier Counties, Florida: in Braunstein, J. (editor), North American oil and gas fields: American Association of Petroleum Geologists Memoir 24, p. 287-299.

Vinet, M. J., 1984, Geochemistry and origin of Smackover and Buckner dolomites (Upper Jurassic), Jay field area, Alabama-Florida: in Ventress, W. P. S., Bebout, D. G., Perkins, B. F., and Moore, C. H. (editors), The Jurassic of the Gulf Rim: Proceedings of the third annual research conference, Gulf Coast 
Section, Society of Economic Paleontologists and Mineralogists Foundation, p. 365-374.

World Oil, 1996, Crude output drops again, gas levels off: World Oil, February 1996, v. 217, no.2, p. 69. 
APPENDIX 1. FLORIDA OIL FIELD DISCOVERY WELL DATA

\begin{tabular}{|c|c|c|c|c|c|c|c|c|c|}
\hline $\begin{array}{l}\text { DISCOVERY } \\
\text { DATE }\end{array}$ & $\begin{array}{l}\text { PERMIT } \\
\text { NO. }\end{array}$ & FIELD & COUNTY & $\begin{array}{l}\text { DATUM FOR DEPTH } \\
\text { MEASUREMENTS, } \\
\text { FT. MSL (1) }\end{array}$ & $\begin{array}{l}\text { PERFORATIONS } \\
\text { OR OPEN HOLE } \\
\text { DEPTH BELOW } \\
\text { DATUM, FT. } \\
\end{array}$ & $\begin{array}{l}\text { TOTAL DEPTH } \\
\text { BELOW DATUM, } \\
\text { FT. }\end{array}$ & $\begin{array}{l}\text { PRODUCING } \\
\text { FORMATION }\end{array}$ & $\begin{array}{l}\text { DISCOVERY } \\
\text { STATUS }\end{array}$ & $\begin{array}{l}\text { OIL GRAVITY, } \\
\text { DEGREES API }\end{array}$ \\
\hline $9-26-43$ & 42 & Sunniland & Collier & 34 (DF) & $11,602-11,626$ & 11,626 & Sunniland & Pumping & 26 \\
\hline $2 \cdot 1.54$ & 167 & Forty Mile Bend & Dade & 24 (DF) & $11,322-11,339$ & 11,557 & Sunniland & Pumping & 21 \\
\hline $7-22.64$ & 315 & Sunoco Felda & Hendry & 55 & $11,472-11,485$ & 11,485 & Sunniland & Pumping & 25 \\
\hline $8-2-66$ & 371 & West Felda & Hendry & 49 & $11,486 \cdot 11,489$ & 11,675 & Sunniland & Pumping & 26 \\
\hline $3.30-69$ & 401 & Lake Trafford & Collier & 40 & $11,870-11,892$ & 11,987 & Sunniland & Pumping & 26 \\
\hline $6-15-70$ & 417 & Jay & Santa Rosa & 206 & $15,470-15,524$ & 15,984 & $\begin{array}{l}\text { Smackover } \\
\text { \& Norphlet }\end{array}$ & Flowing & 51 \\
\hline $\mid 12-19-71$ & 504 & Mt. Carmel & Santa Rosa & 274 & $15,260-15,280$ & 15,399 & $\begin{array}{l}\text { Smackiover } \\
\& \text { Norphlet }\end{array}$ & Flowing & 47 \\
\hline $2 \cdot 14-72$ & 523 & Blackjack Creek & Santa Rosa & 157 & 15,790-15,900 & 16,235 & $\begin{array}{l}\text { Smackover } \\
\text { \& Norphlet }\end{array}$ & Flowing & 51 \\
\hline $12 \cdot 5 \cdot 72$ & 563 & Bear Island & Collier & 31 & $11,589-11,595$ & 11,817 & Sunniland & Pumping & 26 \\
\hline $11-14-73$ & 662 & Seminole & Hendry & 36 & $11,415-11,420$ & 11,651 & Sunniland & Pumping & 25 \\
\hline $7-30-74$ & 712 & Lehigh Park & Lee & 40 & $11,389-11,394$ & 11,630 & Sunniland & Pumping & 28 \\
\hline $4-22-77$ & 881 & Sweetwater Creek & Santa Rosa & 255 & $14,299-14,340$ & 14,611 & Smackover & Pumping & 45 \\
\hline $8-11-77$ & 865 & Baxter Island & Collier & 30 & $11,512-11,515$ & 11,823 & Sunniland & Pumping & 22 \\
\hline 10.13-77 & 904 & Mid-Felda & Hendry & 59 & $11,492-11,496$ & 11,686 & Sunniland & Pumping & 26 \\
\hline $6 \cdot 20.78$ & 829 & Raccoon Point & Collier & 39 & $11,410-11,414$ & 11,658 & Sunniland & Pumping & 23 \\
\hline $9-28-78$ & 897 & Pepper Hammock & Collier & 43 & $11,629 \cdot 11,633$ & 11,897 & Sunniland & Pumping & 27 \\
\hline $6.27-82$ & 1070 & Townsend Canal & Hendry & 53 & $11,416-11,421$ & 11,462 & Sunniland & Pumping & 28 \\
\hline $3 \cdot 25 \cdot 84$ & 1125 & Bluff Springs & Escambia & 178 & $16,332 \cdot 16,339$ & 16,800 & Smackover & Flowing & 57 \\
\hline $11 \cdot 10.85$ & 1170 & Corkscrew & Collier & 45 & $11,547-11,565$ & 11,565 & Sunniland & Pumping & 26 \\
\hline 2-19-86 & 1194 & McLellan & Santa Rosa & 245 & $14,072 \cdot 14,090$ & 14,475 & Smackover & Flowing & 41 \\
\hline 6-4-88 & 1220 & Coldwater Creek & Santa Rosa & 166 & $15,150-15,170$ & 15,407 & Smackover & Flowing & 47 \\
\hline 6-14-88 & 1230 & McDavid & Escambia & 271 & $16,346 \cdot 16,360$ & 16,800 & Smackover & Flowing & 54 \\
\hline
\end{tabular}

1. This is usually the kelly bushing elevation; where this is unavailable, drill floor (DF) elevation is given. 
APPENDIX 2. 1994, 1995 AND CUMULATIVE PRODUCTION DATA (1)

\begin{tabular}{|c|c|c|c|c|c|c|c|c|}
\hline \multirow[b]{2}{*}{ FIELD (2) } & \multicolumn{3}{|c|}{1994 PRODUCTION } & \multicolumn{3}{|c|}{1995 PRODUCTION } & \multicolumn{2}{|c|}{$\begin{array}{l}\text { CUMULATIVE } \\
\text { PRODUCTION }\end{array}$} \\
\hline & $\begin{array}{c}\text { Oil } \\
\text { (Bbls) }\end{array}$ & $\begin{array}{l}\text { Gas } \\
\text { (MCF) }\end{array}$ & $\begin{array}{l}\text { Water } \\
\text { (Bbls) }\end{array}$ & $\begin{array}{c}\text { Oil } \\
\text { (Bbls) }\end{array}$ & $\begin{array}{l}\text { Gas } \\
\text { (MCF) }\end{array}$ & $\begin{array}{l}\text { Water } \\
\text { (Bbls) }\end{array}$ & $\begin{array}{c}\text { Oil } \\
\text { (MBbls) }\end{array}$ & $\begin{array}{c}\text { Gas } \\
\text { (MMCF) }\end{array}$ \\
\hline \multicolumn{9}{|l|}{ NORTHWEST FLORIDA } \\
\hline Bluff Springs (3) & 0 & 0 & 0 & 0 & 0 & 0 & 242 & 129 \\
\hline McDavid (3) & 0 & 0 & 0 & 0 & 0 & 0 & 150 & 62 \\
\hline Jay (Fla. only) & $4,159,336$ & $7,410.410$ & $55,199,267$ & $3,810,967$ & $6,230,813$ & $61,436,742$ & 387,816 & 505,234 \\
\hline Jay (Fla. + Ala.) & $4,580,107$ & $8,043,399$ & $60,918,577$ & $4,076,430$ & $6,613,768$ & $67,047,142$ & & \\
\hline Coldwater Creek & 32,699 & 0 & 116,915 & 3,404 & 0 & 16,753 & 81 & 14 \\
\hline Blackjack Creek & 354,722 & 814,154 & $8,505,848$ & 301,964 & 738,079 & $8,595,142$ & 56,805 & 57,325 \\
\hline Me. Carmel & 20,725 & 0 & 160,721 & 2,737 & 0 & 45,557 & 4,770 & 4,797 \\
\hline McLellan & 24,842 & 7,888 & 35,105 & 17,238 & 4,560 & 39,137 & 352 & 144 \\
\hline Sweetwater Creek (3) & 0 & 0 & 0 & 0 & 0 & 0 & 14 & 15 \\
\hline Subtotal (4) & $4,592,324$ & $8,232,452$ & $64,017,856$ & $4,136,3.10$ & $6,973,452$ & $70,133,331$ & 450,230 & 567,720 \\
\hline \multicolumn{9}{|l|}{ SOUTH FLORIDA } \\
\hline Lehigh Park & 50,153 & 6,318 & 701,074 & 43.271 & 6,318 & 661,097 & 5,462 & 559 \\
\hline Townsend Canal & 2,590 & 0 & 19,578 & 4,816 & 0 & 50,645 & 527 & 0 \\
\hline West Felda & 353,456 & 27,934 & $3,125,074$ & 357,942 & 28,777 & $3,283,230$ & 43,301 & 3,383 \\
\hline Mid-Felda & 17,074 & 0 & 49,992 & 10,299 & 0 & 91,870 & 1,485 & 10 \\
\hline Sunoco Felda (3) & 0 & 0 & 0 & 0 & 0 & 0 & 11,598 & 982 \\
\hline Çorkscrew & 61,667 & 0 & 67,347 & 47,136 & 0 & 59,721 & 967 & 0 \\
\hline Lake Trafford & 0 & 0 & 0 & 0 & 0 & 0 & 278 & 0 \\
\hline Seminole (3) & 0 & 0 & 0 & 0 & 0 & 0 & 85 & 0 \\
\hline Sunniland & 0 & 0 & 0 & 0 & 0 & 0 & 18,445 & 1,825 \\
\hline Bear Island & 123,877 & 24,453 & 458,640 & 90,125 & 23,099 & 275,807 & 11,319 & 942 \\
\hline Pepper Hammock & 0 & 0 & 0 & 0 & 0 & 0 & 0 & 0 \\
\hline Baxter Island (3) & 0 & 0 & 0 & 0 & 0 & 0 & 2 & 0 \\
\hline Raccoon Point & 871,897 & 155,747 & 913,951 & 991,719 & 139,911 & $1,892,882$ & 8,568 & 1,121 \\
\hline Forty Mile Bend (3) & 0 & 0 & 0 & 0 & 0 & 0 & 33 & 2 \\
\hline Subtotal & $1,480,714$ & 214,452 & $5,335,656$ & $1,545,308$ & 198,105 & $6,315,252$ & 102,070 & 8,824 \\
\hline STATEWIDE TOTAL & $6,073,038$ & $8,446,904$ & $69,353,512$ & $5,681,618$ & $7,171,557$ & $76,448,583$ & 552,300 & 576,544 \\
\hline \multicolumn{6}{|c|}{$\begin{array}{l}\text { 1. Statistics compiled by Jim LeBar, Petroleum Engineer, Florida Geological Survey, Oil and Gas Section. } \\
\text { 2. Fields are listed in approximate order from north to south and west to east. } \\
\text { 3. Plugged and abandoned oil fields. } \\
\text { 4. Northwest Florida subtotals use Jay (FL only) data. }\end{array}$} & \multicolumn{3}{|c|}{$\begin{array}{l}\text { Bbls - Barrels ( } 42 \text { US Gallons) } \\
\text { MBbls - Thousand Barrels } \\
\text { MCF - Thousand Cubic Feet } \\
\text { MMCF - Million Cubic Feet }\end{array}$} \\
\hline
\end{tabular}


Information Circular 111

APPENDIX 3. 1994 AND 1995 FIELD WELL STATISTICS (1)

\begin{tabular}{|c|c|c|c|c|c|c|c|c|c|c|}
\hline \multirow[b]{2}{*}{ FIELD (2) } & \multicolumn{5}{|c|}{$\begin{array}{c}1994 \\
\text { Number of Wells }\end{array}$} & \multicolumn{5}{|c|}{$\begin{array}{c}1995 \\
\text { Number of Wells }\end{array}$} \\
\hline & PRO & INJ & $\mathrm{SI}$ & TA & TOTAL & PRO & INJ & SI & TA & TOTAL \\
\hline \multicolumn{11}{|l|}{ NORTHWEST FLORIDA } \\
\hline Jay & 43 & 31 & 35 & 0 & 109 & 51 & 27 & 32 & 1 & 111 \\
\hline Coldwater Creek & 1 & 0 & 0 & 0 & 1 & 0 & 0 & 1 & 0 & 1 \\
\hline Blackjack Creek & 8 & 10 & 3 & 0 & 21 & 10 & 9 & 2 & 1 & 22 \\
\hline Mt. Carmel & 1 & 0 & 0 & 0 & 1 & 0 & 0 & 1 & 0 & 1 \\
\hline McLellan & 2 & 0 & 0 & 0 & 2 & 2 & 0 & 0 & 0 & 2 \\
\hline Subtotal & 55 & 41 & 38 & 0 & 134 & 63 & 36 & 36 & 2 & 137 \\
\hline \multicolumn{11}{|l|}{ SOUTH FLORIDA } \\
\hline Lehigh Park & 1 & 0 & 0 & 0 & 1 & 1 & 0 & 0 & 0 & 1 \\
\hline Townsend Canal & 1 & 0 & 3 & 0 & 4 & 1 & 0 & 1 & 0 & 2 \\
\hline West Felda & 8 & 0 & 15 & 0 & 23 & 6 & 0 & 11 & 2 & 19 \\
\hline Mid-Felda & 1 & 0 & 1 & 0 & 2 & 2 & 0 & 0 & 0 & 2 \\
\hline Sunoco Felda & 0 & 0 & 4 & 0 & 4 & 0 & 0 & 0 & 0 & 0 \\
\hline Corkscrew & 3 & 0 & 0 & 0 & 3 & 3 & 0 & 0 & 0 & 3 \\
\hline Lake Trafford & 0 & 0 & 1 & 0 & 1 & 0 & 0 & 1 & 0 & 1 \\
\hline Sunniland & 0 & 0 & 4 & 0 & 4 & 0 & 0 & 2 & 0 & 2 \\
\hline Bear Island & 6 & 0 & 9 & 0 & 15 & 5 & 0 & 8 & 0 & 13 \\
\hline Pepper Hammock & 0 & 0 & 1 & 0 & 1 & 0 & 0 & 1 & 0 & 1 \\
\hline Raccoon Point & 5 & 0 & 7 & 0 & 12 & 6 & 0 & 7 & 0 & 13 \\
\hline Subtotal & 25 & 0 & 45 & 0 & 70 & 24 & 0 & 31 & 2 & 57 \\
\hline STATEWIDE TOTAL & 80 & 41 & 83 & 0 & 204 & 87 & 36 & 67 & 4 & 194 \\
\hline
\end{tabular}

1. 1994 statistics compiled by Charlos Tootlo, Potroloum Engineer, Florida Goological Survey, Oil and Gas Section. 1995 statistics compiled by Jim LeBar, Potroloum Engineer, Florida Geological Survey, Oil and Gas Soction.

2. Fields are listed in approximate order from north to south and west to east.

Abbroviations:

PRO - Producing Wolls

INJ -.Injoction Wolls

SI - Shut In Wolls

TA - Tomporarily Abandoned Wolls 


\section{Florida Geological Survey}

APPENDIX 4. 1994 AND 1995 FIELD WELLS DRILLED

\begin{tabular}{|c|c|c|c|c|c|c|c|}
\hline $\begin{array}{l}\text { FIELD } \\
\text { County } \\
\end{array}$ & Permit No. & $\begin{array}{l}\text { Operator-Well } \\
\text { Name \& No. }\end{array}$ & Location (1) & $\begin{array}{c}\text { Completion } \\
\text { Date }\end{array}$ & $\begin{array}{l}\text { Drill Floor } \\
\text { Elev., Ft. } \\
\text { Above MSL } \\
\end{array}$ & $\begin{array}{l}\text { Total } \\
\text { Depth } \\
\text { Ft. (2) } \\
\end{array}$ & Comments \\
\hline $\begin{array}{l}\text { MT. CARMEL } \\
\text { Santa Rosa }\end{array}$ & P-1286 & $\begin{array}{l}\text { Daniels Corp.: } \\
\text { Hendricks } 2-1 \text {, } \\
\text { No. } 2\end{array}$ & $\begin{array}{c}\text { SHL: } 980^{\circ} \text { FWL \& } \\
1680^{\circ} \mathrm{FSL} \\
\text { Sec. } 2 \\
\text { T5N, R29W } \\
\text { BHL: Not available. }\end{array}$ & $\begin{array}{l}01 / 29 / 95 \\
\text { (3) }\end{array}$ & 273 & $\begin{array}{l}\text { MD: } 15,370 \\
\text { TVD: } 15,350\end{array}$ & $\begin{array}{l}\text { Top of Smackover: } 15,082^{\prime} \text {. } \\
\text { Top of Norphlet: } 15,310^{\prime} \text {. } \\
\text { Well sidetracked, P-1286A. }\end{array}$ \\
\hline Santa Rosa & $P-1286 A$ & $\begin{array}{l}\text { Daniels Corp.: } \\
\text { Hendricks 2-1, } \\
\text { No. } 2 \text {, ST } 1\end{array}$ & $\begin{array}{c}\text { SHL: } 980^{\prime} \mathrm{FWL} \& \\
1680^{\circ} \mathrm{FSL} \\
\text { Sec. } 2 \text {, } \\
\text { T5N, R29W } \\
\text { BHL: } 1305^{\prime} \text { FWL \& } \\
1405^{\prime} \mathrm{FSL} \\
\text { Sec. 2, } \\
\text { T5N, R29W }\end{array}$ & $03 / 09 / 95$ & 273 & $\begin{array}{l}\text { MD: } 15,511 \\
\text { TVD: } 15,442\end{array}$ & $\begin{array}{l}\text { Top of Smackover: } 15,164^{\prime} . \\
\text { Top of Norphlet: } 15,418^{\prime} . \\
\text { Dry hole, in process of } \\
\text { plugging } \& \text { abandonment. }\end{array}$ \\
\hline
\end{tabular}

1) Directionally drilled well; SHL is surface hole location, BHL is bottom hole location.

2) MD: measured depth, TVD: true vertical depth.

3) Directional survey to total depth not supplied by oper ator. Hole location at a depth of $14,754^{\prime}$ was 1,711' FSL and 587' FWL, Sec. 2, T5N, R29W.

APPENDIX 5. EXPLORATORY WELL DRILLED IN 1993, COMPLETION REPORT RECEIVED IN 1994

\begin{tabular}{|c|c|c|c|c|c|c|c|}
\hline County & Permit No. & $\begin{array}{l}\text { Operator-Well } \\
\text { Name \& No. }\end{array}$ & Location & $\begin{array}{c}\text { Completion } \\
\text { Date }\end{array}$ & $\begin{array}{l}\text { Drill Floor } \\
\text { Elev., Ft. } \\
\text { Above MSL }\end{array}$ & $\begin{array}{l}\text { Total } \\
\text { Depth } \\
\text { Ft. }\end{array}$ & Comments \\
\hline Santa Rosa & P-1285 & $\begin{array}{l}\text { Mack Oil Corp.- } \\
\text { Champion 23-1 }\end{array}$ & $\begin{array}{l}1339^{\circ} \text { FNL \& } \\
1274^{\circ} \text { FEL } \\
\text { Sec. } 23 \text {, } \\
\text { T3N, R28W }\end{array}$ & $11 / 07 / 93$ & 186 & 16,600 & $\begin{array}{l}\text { Target: Smackover Fm. } \\
\text { Top of Smackover: } 16,145^{\circ} \text {. } \\
\text { Plugged } \& \text { abandoned } \\
\text { as a dry hole, } 11 / 10 / 93 .\end{array}$ \\
\hline
\end{tabular}


Information Circular 111

APPENDIX 6. OIL EXPLORATION WELLS DRILLED IN STATE WATERS (1)

\begin{tabular}{|c|c|c|c|c|c|c|c|}
\hline Year & $\begin{array}{l}\text { Permit and } \\
\text { Well(2) No. }\end{array}$ & Operator & $\begin{array}{l}\text { Lease No. } \\
\text { and Area }\end{array}$ & County & $\begin{array}{c}\text { Rotary } \\
\text { Table Elev. } \\
\text { Ft. above MSL }\end{array}$ & $\begin{array}{c}\text { Total } \\
\text { Depth, Ft. }\end{array}$ & $\begin{array}{c}\text { Geological } \\
\text { Significance }\end{array}$ \\
\hline 1947 & $\begin{array}{l}P-16 \\
W-1413\end{array}$ & $\begin{array}{l}\text { Gulf Oil } \\
\text { Corp. }\end{array}$ & $\begin{array}{l}\text { State of Florida } \\
\text { Lease } 374 \text { No. } 1 \\
\text { Sugarloaf Key Area }\end{array}$ & $\begin{array}{l}\text { offshore } \\
\text { Monroe }\end{array}$ & 23 & 6,100 & Bottomed in Upper Cretaceous(?). \\
\hline 1947 & $\begin{array}{l}P-22 \\
W-972\end{array}$ & $\begin{array}{l}\text { Gulf Oil } \\
\text { Corp. }\end{array}$ & $\begin{array}{l}\text { State of Florida } \\
\text { Lease } 373 \text { No. } 1 \\
\text { Big Pine Key Area }\end{array}$ & $\begin{array}{l}\text { offshore } \\
\text { Monroe }\end{array}$ & 23 & 15,455 & $\begin{array}{l}\text { No porosity in Sunniland Fm. } \\
\text { Well bottomed in Pumpkin Bay } \\
\text { Fm. Very difficult to correlate } \\
\text { this well because of anhydrite } \\
\text { development. Structurally very } \\
\text { low. }\end{array}$ \\
\hline 1947 & $\begin{array}{l}P-43 \\
W-1502\end{array}$ & $\begin{array}{l}\text { Magnolia } \\
\text { Petroleum } \\
\text { Co. }\end{array}$ & $\begin{array}{l}\text { State of Florida } \\
\text { Block 5-B No. 1-A } \\
\text { St. Vincent Sound }\end{array}$ & $\begin{array}{l}\text { offshore } \\
\text { Franklin }\end{array}$ & 10 & 7,019 & Bottomed in Lower Cretaceous. . \\
\hline 1955 & $\begin{array}{l}P-232 \\
W-3510 C\end{array}$ & $\begin{array}{l}\text { Gulf Oil } \\
\text { Corp. }\end{array}$ & $\begin{array}{l}\text { State of Florida } \\
\text { Lease } 826-\text { G No. } 1 \\
\text { Florida Bay }\end{array}$ & $\begin{array}{l}\text { offshore } \\
\text { Monroe }\end{array}$ & 32 & 12,631 & $\begin{array}{l}\text { Well cored from } 11,661-12,544^{\prime} \\
\text { in Sunniland Fm. and Punta Gorda } \\
\text { Anhydrite. Encountered some salt } \\
\text { stringers in Punta Gorda. Only 60' } \\
\text { of dark dense calcilutite in Sunni- } \\
\text { land Fm. }\end{array}$ \\
\hline 1956 & $\begin{array}{l}P-251 \\
W-4122\end{array}$ & HORC & $\begin{array}{l}\text { State of Florida } \\
\text { Lease } 833 \text { No. } 1 \\
\text { Pensacola Bay }\end{array}$ & $\begin{array}{l}\text { offshore } \\
\text { Santa Rosa }\end{array}$ & 26 & 7,505 & Bottomed in Lower Cretaceous. \\
\hline 1959 & $\begin{array}{l}P-275 \\
W-5094\end{array}$ & $\begin{array}{l}\text { Gulf Oil } \\
\text { Corp. }\end{array}$ & $\begin{array}{l}\text { State of Florida } \\
\text { Lease } 826-Y \text { No. } 1 \\
\text { Marquesas }\end{array}$ & $\begin{array}{l}\text { offshore } \\
\text { Monroe }\end{array}$ & 56 & 15,478 & $\begin{array}{l}\text { Four drill stem tests: } \\
12,474-12,533^{\prime} \text { ' (Lake Trafford? Fm.) } \\
12,534-12,544^{\prime} \text { ' (Sunniland Fm.) } \\
12,582-12,822^{\prime} \text { (Sunniland Fm.) } \\
14,642-14,702^{\prime} \text { (Brown Dolomite } \mathrm{Zn} \text {.) } \\
\text { The } 12,474-12,533^{\prime} \text { test recovered } \\
15 \text { barrels of } 22 \text { degree API } \\
\text { gravity oil and } 14.1 \text { barrels of } \\
\text { saltwater. Brown Dolomite from } \\
14,650-15,036^{\prime} \text { was somewhat } \\
\text { vuggy. This may be the principal } \\
\text { target in this area. Net dolomite } \\
\text { estimated at } 400^{\prime} \text {. }\end{array}$ \\
\hline 1959 & $\begin{array}{l}P-280 \\
W-5152\end{array}$ & $\begin{array}{l}\text { California } \\
\text { Coastal }\end{array}$ & $\begin{array}{l}\text { State of Florida } \\
\text { Lease } 1011 \text { No. } 1 \\
\text { Big Pine Key Area }\end{array}$ & $\begin{array}{l}\text { offshore } \\
\text { Monroe }\end{array}$ & 21 & 6,030 & Bottomed in Lower Cretaceous. \\
\hline 1959 & $\begin{array}{l}P-281 \\
W-5103\end{array}$ & $\begin{array}{l}\text { California } \\
\text { Coastal }\end{array}$ & $\begin{array}{l}\text { State of FLorida } \\
\text { Lease } 224-A \text { No. } 1 \\
\text { St. George Island } \\
\text { Area }\end{array}$ & $\begin{array}{l}\text { offshore } \\
\text { Franklin }\end{array}$ & 26 & 7,030 & Bottomed in Lower Cretaceous. \\
\hline 1960 & $\begin{array}{l}P-289 \\
W-5574\end{array}$ & $\begin{array}{l}\text { California } \\
\text { Coastal }\end{array}$ & $\begin{array}{l}\text { State of Florida } \\
\text { Lease 224-B No. } 1 \\
\text { Boca Grande Area }\end{array}$ & $\begin{array}{l}\text { offshore } \\
\text { Le日 }\end{array}$ & 39 & 14,000 & $\begin{array}{l}\text { Brown Dolomite: } 12,485-12,589^{\prime} \\
\text { Estimated net dolomite: } 103^{\prime}\end{array}$ \\
\hline 1961 & $\begin{array}{l}P-292 \\
W-5713\end{array}$ & $\begin{array}{l}\text { California } \\
\text { Coastal }\end{array}$ & $\begin{array}{l}\text { State of Florida } \\
\text { Lease } 1011 \text { No. } 2 \\
\text { Marquesas }\end{array}$ & $\begin{array}{l}\text { offshore } \\
\text { Monroe }\end{array}$ & 36 & 7,722 & Bottomed in Lower Cretaceous. \\
\hline 1961 & $\begin{array}{l}P-293 \\
W-5654\end{array}$ & $\begin{array}{l}\text { California } \\
\text { Coastal }\end{array}$ & $\begin{array}{l}\text { State of Florida } \\
\text { Lease } 224 \text {-A No. } 2 \\
\text { South of Alligator } \\
\text { Point }\end{array}$ & $\begin{array}{l}\text { offshore } \\
\text { Franklin }\end{array}$ & 34 & 10,560 & $\begin{array}{l}\text { Did not encounter Smackover Fm. } \\
\text { Bottomed in Eagle Mills Fm. of } \\
\text { Triassic age. Diabase found in } \\
\text { Eagle Mills. }\end{array}$ \\
\hline
\end{tabular}

1. Modified from Applegate and Lloyd, 1985.

2. Florida Geological Survey well number for samples (cuttings or core chips). 


\section{Florida Geological Survey}

APPENDIX 6 (cont.). OIL EXPLORATION WELLS DRILLED IN STATE WATERS (1)

\begin{tabular}{|c|c|c|c|c|c|c|c|}
\hline Year & $\begin{array}{l}\text { Permit and } \\
\text { Well(2) No. }\end{array}$ & Operator & $\begin{array}{l}\text { Lease No. } \\
\text { and Area }\end{array}$ & County & $\begin{array}{c}\text { Rotary } \\
\text { Table Elev. } \\
\text { Ft. above MSL }\end{array}$ & $\begin{array}{c}\text { Total } \\
\text { Depth, Ft. }\end{array}$ & $\begin{array}{c}\text { Geological } \\
\text { Significance }\end{array}$ \\
\hline 1961 & $\begin{array}{l}\text { P-297 } \\
W-5785\end{array}$ & $\begin{array}{l}\text { California } \\
\text { Coastal }\end{array}$ & $\begin{array}{l}\text { State of Floridà } \\
\text { Lease 224-B No. } 2 \\
\text { Boca Grande Area }\end{array}$ & $\begin{array}{l}\text { offshore } \\
\text { Lee }\end{array}$ & 40 & 12,600 & $\begin{array}{l}\text { There is an estimated } 40^{\prime} \text { of dolo- } \\
\text { mite in the } 12,445-12,560^{\prime} \text { Brown } \\
\text { Dolomite interval. No evidence of } \\
\text { oil staining. Dolomito microcrys- } \\
\text { talline to finely crystalline. } \\
\text { Core analysis from } 11,255-11,625^{\prime} \\
\text { Sunniland interval showed no } \\
\text { permeability, extremely low por- } \\
\text { osity, and no oil. }\end{array}$ \\
\hline 1962 & $\begin{array}{l}P-298 \\
W-5970\end{array}$ & $\begin{array}{l}\text { California } \\
\text { Coastal }\end{array}$ & $\begin{array}{l}\text { State of Florida } \\
\text { Lease } 1011 \text { No. } 3 \\
\text { Marquesas }\end{array}$ & $\begin{array}{l}\text { offshore } \\
\text { Monroe }\end{array}$ & 57 & 12,850 & $\begin{array}{l}\text { Bottomed in Punta Gorda } \\
\text { Anhydrite. No shows of oil and } \\
\text { no porosity reported. Drill stem } \\
\text { test of the } 12,521-12,600 \text { ' interval } \\
\text { tested salt water. Rebecca Shoals } \\
\text { Reef (Paleocene and Upper } \\
\text { Cretaceous) present. }\end{array}$ \\
\hline 1963 & $\begin{array}{l}P-304 \\
W-6278\end{array}$ & $\begin{array}{l}\text { California } \\
\text { Coastal }\end{array}$ & $\begin{array}{l}\text { State of Florida } \\
\text { Lease 224-B No. } 3 \\
\text { Honeymoon Island } \\
\text { Area }\end{array}$ & $\begin{array}{l}\text { offshore } \\
\text { Pinellas }\end{array}$ & 37 & 10,600 & $\begin{array}{l}\text { Bottomed in Lower Cretaceous. } \\
\text { Very poor samples. No oil shows. } \\
\text { Carbonates-clastics below } 7,000^{\circ} \text {. }\end{array}$ \\
\hline 1967 & $\begin{array}{l}\text { P-375 } \\
W-8139\end{array}$ & $\begin{array}{l}\text { Mobil Oil } \\
\text { Corp. }\end{array}$ & $\begin{array}{l}\text { State of Florida } \\
\text { Lease } 224 \text {-B No. } 1 \\
\text { Boca Grande Area }\end{array}$ & $\begin{array}{l}\text { offshore } \\
\text { Charlotte }\end{array}$ & 21 & 12,931 & $\begin{array}{l}\text { This well drilled into Pumpkin } \\
\text { Bay Fm. at } 12,230^{\prime} \text {. Drilled } \\
\text { into basement (rhyolite porphyry) } \\
\text { at } 12,830^{\prime} \text {. No shows in Sunniland } \\
\text { Fm. Brown Dolomite Zone: } \\
11,920-12,000 ' \text {. Estimated net } \\
\text { dolomite: 70'. Poor samples. }\end{array}$ \\
\hline 1967 & $\begin{array}{l}P-382 \\
W-8304\end{array}$ & $\begin{array}{l}\text { Mobil Oil } \\
\text { Corp. }\end{array}$ & $\begin{array}{l}\text { State of Florida } \\
\text { Lease 224-A No. 1-A } \\
\text { W-SW of Crystal } \\
\text { River }\end{array}$ & $\begin{array}{l}\text { offshore } \\
\text { Citrus }\end{array}$ & 22 & 6,041 & $\begin{array}{l}\text { Mixed facies (carbonates, sand- } \\
\text { stones, and shales) at } 4,325^{\prime} ; \\
\text { Triassic, Eagle Mills at } 5,625^{\prime} ; \\
\text { Paleozoic at } 5,920^{\prime} \text {. Very indur- } \\
\text { ated shale and siltstone. Some } \\
\text { quartzite. Bedding planes verti- } \\
\text { cal in this core. No shows and no } \\
\text { porosity. }\end{array}$ \\
\hline 1967 & $\begin{array}{l}P-383 \\
W-8305\end{array}$ & $\begin{array}{l}\text { Mobil Oil } \\
\text { Corp. }\end{array}$ & $\begin{array}{l}\text { State of Florida } \\
\text { Lease 224-A No. 1-B } \\
\text { Cedar Key Area }\end{array}$ & $\begin{array}{l}\text { offshore } \\
\text { Levy }\end{array}$ & 25 & 4,735 & $\begin{array}{l}\text { Mixed facies (carbonates, sand- } \\
\text { stones, and shales) at } 2,882^{\prime} \text { in } \\
\text { Cretaceous. Predominantly vari- } \\
\text { colored unconsolidated sandstone } \\
\text { below } 4,180^{\prime} \text {. Highly indurated } \\
\text { quartzites and interbedded shales } \\
\text { in core (Paleozoic) from } 4,720 \\
4,735^{\prime} \text {. }\end{array}$ \\
\hline 1968 & $\begin{array}{l}P-387 \\
W-8487\end{array}$ & $\begin{array}{l}\text { Mobil Oil } \\
\text { Corp. }\end{array}$ & $\begin{array}{l}\text { State of Florida } \\
\text { Lease 224-A No. 1-C } \\
\text { Little St. George } \\
\text { Island Area }\end{array}$ & $\begin{array}{l}\text { offshore } \\
\text { Franklin }\end{array}$ & 37 & 14,369 & $\begin{array}{l}\text { This well encountered Jurassic } \\
\text { limestone. First indication of } \\
\text { possible Smackover Fm. in Apa- } \\
\text { lachicola area. }\end{array}$ \\
\hline $198 \dot{3}$ & $\begin{array}{l}\text { P-1097 } \\
W-15391\end{array}$ & $\begin{array}{l}\text { Getty Oil } \\
\text { Company }\end{array}$ & $\begin{array}{l}\text { State of Florida } \\
\text { Lease } 2338 \text { No. } 1 \\
\text { East Bay }\end{array}$ & $\begin{array}{l}\text { offshore } \\
\text { Santa Rosa }\end{array}$ & 30 & 18,011 & $\begin{array}{l}\text { Smackover tests at } 17,405-17,411^{\circ} \\
\text { and } 17,328-17,411^{\prime} \text { produced only } \\
\text { saltwater. Norphlet Ss. and Louann/ } \\
\text { Werner evaporites were very thin. }\end{array}$ \\
\hline
\end{tabular}

2. Florida Geological Survey well number for samples (cuttings or core chips). 
APPENDIX 7. 1994 AND 1995 GEOPHYSICAL EXPLORATION ACTIVITY

\begin{tabular}{|c|c|c|c|c|c|c|c|c|}
\hline \multirow[b]{2}{*}{ PERMIT } & \multirow{2}{*}{$\begin{array}{l}\text { GEOPHYSICAL } \\
\text { COMPANY }\end{array}$} & \multirow[b]{2}{*}{ COUNTY } & \multirow{2}{*}{$\begin{array}{c}\text { PERMIT } \\
\text { APPROVED }\end{array}$} & \multirow{2}{*}{$\begin{array}{c}\text { EXPIRATION } \\
\text { DATE }\end{array}$} & \multirow[b]{2}{*}{ STATUS } & \multirow{2}{*}{$\begin{array}{l}\text { ENERGY } \\
\text { SOURCE }\end{array}$} & \multicolumn{2}{|c|}{ SURVEY LENGTH, MI } \\
\hline & & & & & & & APPROVED & SURVEYED \\
\hline G-152-93 & $\begin{array}{l}\text { Universal Seismic } \\
\text { Acquisition Inc. }\end{array}$ & Santa Rosa & 03-Mar-94 & 03-Mar-95 & Completed & $\begin{array}{l}\text { Seismic } \\
\text { Explosives }\end{array}$ & 22.5 & 22.5 \\
\hline G-153-93 & $\begin{array}{l}\text { Triton Energy } \\
\text { Company }\end{array}$ & Highlands & 23-Nov-93 & 23-Nov-94 & Completed & Gravity & 102.0 & 102.0 \\
\hline G-154-95 & $\begin{array}{l}\text { Calumet Florida } \\
\text { Inc. }\end{array}$ & $\begin{array}{l}\text { Lee, Hendry, } \\
\& \text { Collier }\end{array}$ & 24-Mar-95 & 23-Mar-96 & In Progress & $\begin{array}{l}\text { Seismic } \\
\text { Explosives }\end{array}$ & 52.4 & 20.3 \\
\hline G-155-95 & $\begin{array}{l}\text { Coastal } \\
\text { Petroleum }\end{array}$ & Offshore & $\begin{array}{l}\text { Application } \\
\text { Pending }\end{array}$ & & & $\begin{array}{l}\text { Airgun and } \\
\text { Gravity/Magnetic }\end{array}$ & $\begin{array}{l}\text { Dense grid: Ap } \\
\text { Mileage not giv }\end{array}$ & $\begin{array}{l}\text { to Naples. } \\
\text { lication. }\end{array}$ \\
\hline & & & & & $\begin{array}{l}\text { Total Miles } \\
\text { Survey Miles }\end{array}$ & $\begin{array}{l}\text { n Applications: } \\
\text { by Area: } \\
\text { North Florida: } \\
\text { South Florida: }\end{array}$ & $\begin{array}{r}176.9 \\
\\
22.5 \\
154.4\end{array}$ & $\begin{array}{r}144.8 \\
\\
22.5 \\
122.3\end{array}$ \\
\hline
\end{tabular}


APPENDIX 8. FLORIDA OIL AND GAS RESERVE ESTIMATES (1)

\begin{tabular}{|c|c|c|c|c|c|c|c|c|c|c|c|c|}
\hline FIELD (2) & $\begin{array}{c}\text { OIL } \\
\text { GRAVITY, } \\
\text { A.P.I, }\end{array}$ & $\begin{array}{l}\text { AVERAGE } \\
\text { POROSITY, } \\
\text { PERCENT }\end{array}$ & $\begin{array}{l}\text { PRODUC. } \\
\text { TIVE } \\
\text { AERES }\end{array}$ & $\begin{array}{l}\text { AVERAGE } \\
\text { GAS-OIL } \\
\text { RATIO, } \\
\text { SCF/STB } \\
\end{array}$ & $\begin{array}{l}\text { ORIGINAL } \\
\text { OIL IN } \\
\text { PLACE, } \\
\text { BARRELS }\end{array}$ & $\begin{array}{l}\text { ESTIMATE } \\
\text { RECOVERY } \\
\text { FACTOR, } \\
\text { FRACTION }\end{array}$ & $\begin{array}{l}\text { ORIGINAL } \\
\text { RECOVER- } \\
\text { ABLE OIL } \\
\text { IN PLACE, } \\
\text { BARRELS }\end{array}$ & $\begin{array}{c}\text { OIL } \\
\text { PRODUCED } \\
\text { THROUGH } \\
1-1.96, \\
\text { BARRELS } \\
\end{array}$ & $\begin{array}{c}\text { REMAINING } \\
\text { RECOVERABLE } \\
\text { OIL RESERVES } \\
\text { AS OF } 1 \cdot 1 \cdot 96, \\
\text { BARRELS } \\
\end{array}$ & $\begin{array}{c}\text { ORIGINAL } \\
\text { RECOVER- } \\
\text { ABLE GAS } \\
\text { IN PLACE, } \\
\text { MCF }\end{array}$ & $\begin{array}{c}\text { GAS } \\
\text { PRODUCED } \\
\text { THROUGH } \\
1.1 \cdot 96 \\
\text { MCF } \\
\end{array}$ & $\begin{array}{c}\text { REMAINING } \\
\text { RECOVERABLE } \\
\text { GAS RESERVES } \\
\text { AS OF } 1 \cdot 1.96, \\
\text { MCF } \\
\end{array}$ \\
\hline \multicolumn{13}{|l|}{ NORTHWEST FLORIDA } \\
\hline Bluff Springs (3) & 53 & 19.6 & 160.00 & 550 & $1,300,440$ & 0.19 & 247,084 & 241,871 & 5,213 & 135,795 & 128,565 & 7,230 \\
\hline McDavid (3) & 53 & 12.8 & 160.00 & 400 & $4,987,347$ & 0.10 & 498,736 & 150,323 & 348,413 & 199,494 & 61,859 & 137,635 \\
\hline Jay (FL \& AL) & 51 & 14.0 & $14,414.50$ & 1,277 & $820,569,503$ & 0.60 & $492,341,702$ & $419,824,453$ & $72,517,249$ & $628,720,354$ & $547,251,409$ & $81,468,945$ \\
\hline Jay (FL only) & 51 & 14.0 & $13,021.14$ & 1,277 & $763,129,638$ & 0.60 & $457,877,783$ & $387,815,585$ & $70,062,198$ & $584,709,929$ & $505,234,204$ & $79,475,725$ \\
\hline Coldwater Crook & 47 & 12.1 & 160.00 & 500 & $2,080,107$ & 0.15 & 312,016 & 80,068 & 231,948 & 156,008 & 14,012 & 141,996 \\
\hline Blackjack Crook & 48 & 16.5 & $5,719.98$ & 954 & $100,500,000$ & 0.60 & $60,300,000$ & $56,805,223$ & $3,494,777$ & $57,526,200$ & $57,324,872$ & 201,328 \\
\hline Mt. Carmol & 43 & 9.1 & 481.28 & 1,028 & $17,500,000$ & 0.29 & $5,075,000$ & $4,770,745$ & 304,255 & $5,218,140$ & $4.797,292$ & 420,848 \\
\hline McLollan & 43 & 9.0 & 480.00 & 430 & $2,915,540$ & 0.14 & 412,686 & 351,617 & 61,069 & 177,455 & 143,494 & 33,961 \\
\hline Swootwater Crook (3) & 44 & 11.0 & 160.00 & 1,070 & 624,000 & 0.10 & 62,400 & 13,695 & 48,705 & 66,768 & 14,655 & 52,113 \\
\hline Subtotal (4) & & & $20,342.40$ & & $893,037,072$ & & $524,785,705$ & $450,229,127$ & $74,556,578$ & $648,189,789$ & $567,718,953$ & $80,470,83$ \\
\hline \multicolumn{13}{|l|}{ SOUTH FLORIDA } \\
\hline Lehigh Park & 28 & 17.7 & 800.00 & 100 & $8,211,707$ & 0.68 & $5,583,961$ & $5,462,076$ & 121,885 & 558,396 & 558,161 & 235 \\
\hline Townsend Canal & 28 & 13.7 & 640.00 & $\circ$ & $4,504,699$ & 0.20 & 900,940 & 526,420 & 374,520 & 0 & 0 & \\
\hline Wost Folda & 26 & 15.0 & $7,500.00$ & 80 & $125,802,366$ & 0.35 & $44,030,828$ & $43,301,266$ & 729,562 & $3,522,466$ & $3,383,330$ & 139,136 \\
\hline Mid-Folda & 26 & 11.9 & 480.00 & 10 & $5,090,419$ & 0.30 & $1,527,126$ & $1,484,994$ & 42,132 & 12,726 & 10,094 & 2,632 \\
\hline Sunoco Folda (3) & 25 & 15.0 & $3,840.00$ & 85 & $28,946,578$ & 0.40 & $11,608,631$ & $11,598,196$ & 10,435 & 984,184 & 981,827 & 2,357 \\
\hline Corkscrow & 26 & 6.9 & 480.00 & 0 & $1,667,806$ & 0.65 & $1,084,074$ & 966,703 & 117,371 & o & 0 & \\
\hline Lake Trafford & 26 & 7.9 & 160.00 & 0 & $7,690,293$ & 0.04 & 307,612 & 278,241 & 29,371 & $\circ$ & 0 & \\
\hline Sominole (3) & 25 & 14.1 & 480.00 & o & $2,366,565$ & 0.10 & 236,657 & 84,755 & 151,902 & 0 & 0 & \\
\hline Sunniland & 26 & 15.0 & $2,080.00$ & 100 & $37,685,118$ & 0.50 & $18,842,559$ & $18,445,245$ & 397,314 & $1,884,256$ & $1,824,628$ & 59,628 \\
\hline Bear Island & 26 & 11.9 & $2,880.00$ & 80 & $42,811,959$ & 0.35 & $14,984,184$ & $11,318,991$ & $3,665,193$ & $1,198,735$ & 941,112 & 257,623 \\
\hline Pepper Hammock & 27 & 15.3 & 160.00 & 0 & 976,713 & 0.10 & 97,671 & 323 & 97,348 & 0 & 0 & \\
\hline Baxter island (3) & 22 & 19.6 & 160.00 & 0 & $1,276,617$ & 0.10 & 127,662 & 1,859 & 125,803 & 0 & 0 & \\
\hline Raccoon Point & 23 & 13.9 & $2,400.00$ & 120 & $42,437,790$ & 0.25 & $10,609,448$ & $8,569,027$ & $2,040,421$ & $1,273,134$ & $1,121,170$ & 151,964 \\
\hline Forty Mile Bend (3) & 21 & 10.0 & 320.00 & 50 & $1,112,701$ & 0.07 & 77.889 & 32,888 & 45,001 & 3,894 & 1,656 & 2,23 \\
\hline Subtotal & & & $22,380.00$ & & $310,581,331$ & & $110,019,242$ & $102,070,984$ & $7,948,258$ & $9,437,791$ & $8,821,978$ & \\
\hline STATEWIDE TOTAL & & & $42,722.40$ & & $1,203,618,403$ & & $634,804,947$ & $552,300,111$ & $82,504,836$ & $657,627,580$ & $576,540,931$ & $31,086,64$ \\
\hline
\end{tabular}

SCF. Standard Cubic Feet

2 Fields are listed in approximate order from northwest to sourheas

STB - Stock Tank Barrels

4. Northwest Florida subtotals use Jay (FL only) data 




\title{
FLORIDA GEOLOGICAL SURVEY \\ $903 \mathrm{~W}$. TENNESSEE STREET \\ TALLAHASSEE, FLORIDA $32304-7700$
}

\section{ADMINISTRATIVE SECTION}

\author{
Walter Schmidt, Chief and State Geologist \\ Cindy Collier, Administrative Secretary \\ Jessie Hawkins, Custodian \\ Deborah Mekeel, Librarian \\ Sandie Ray, Admin. Asst.
}

\section{GEOLOGICAL INVESTIGATIONS SECTION}

Jon Arthur, Petrologist

Thomas M. Scott, Assistant State Geologist

Martin Balinsky, Research Assistant

Jim Balsillie, Coastal Geologist

Clint Barineau, Research Assistant

Paulette Bond, Geochemist

Jennifer Branch, Staff Assistant

Ken Campbell, Sedimentologist

Joel Duncan, Sedimentary Petrologist

Rick Green, Senior Research Assistant

Mark Groszos, Research Assistant

Alex Howell, Research Assistant

Dennis Jensen, Research Assistant

Jim Jones, Cartographer
Lance Johnson, Research Assistant

Ted Kiper, Cartographer

Li Li, Research Assistant

Harley Means, Research Assistant

Tom Miller, Research Assistant

LaMarr Mitchell, Secretary Specialist

Spencer Mitchell, Research Assistant

Stephen Palmes, Research Assistant

Frank Rupert, Paleontologist

Frank Rush, Lab Technician

Jim Trindell, Driller

Rodger VanLandingham, Asst. Driller

Bill Waite, Research Assistant

\section{MINERAL RESOURCE INVESTIGATIONS \\ AND \\ ENVIRONMENTAL GEOLOGY SECTION}

Jacqueline M. Lloyd, Assistant State Geologist

Zi-Quiag Chen, Research Assistant

Adel Dabous, Research Assistant

Rodney DeHan, Sr. Research Scientist

Joe Donoghue, Research Associate

Henry Freedenberg, Env. Geologist

Cliff Hendrickson, Research Assistant

Deborah Harrington, Research Assistant
Ron Hoenstine, Env. Geologist Suvrat Kher, Research Assistant Jim Ladner, Environmental Geologist Ed Lane, Environmental Geologist Steve Spencer, Economic Geologist Nikki Strong, Research Assistant Candy Trimble, Research Assistant Holly Williams, Research Assistant

\section{OIL AND GAS SECTION}

\section{David Curry, Environmental Program Administrator}

Paul Attwood, Asst. Dist. Coordinator

Robert Caughey, District Coordinator

Ed Gambrell, District Coordinator

Ed Garrett, Geologist
Don Hargrove, Engineer

Evelyn Jordan, Sec. Spec. Jim LeBar, Professional Engineer Victoria MacFarlan, Sec. Spec.

\section{Carolyn Stringer, Secrerary Specialist}


